Portland State University

PDXScholar

Winter 4-18-2013

\title{
Effects of HRU Size on PRMS Performance in 30 Western U.S. Basins
}

Madeline Olena Steele

Portland State University

Follow this and additional works at: https://pdxscholar.library.pdx.edu/open_access_etds

Part of the Fresh Water Studies Commons, Other Physical Sciences and Mathematics Commons, and the Water Resource Management Commons

Let us know how access to this document benefits you.

\section{Recommended Citation}

Steele, Madeline Olena, "Effects of HRU Size on PRMS Performance in 30 Western U.S. Basins" (2013). Dissertations and Theses. Paper 654.

https://doi.org/10.15760/etd.654

This Thesis is brought to you for free and open access. It has been accepted for inclusion in Dissertations and Theses by an authorized administrator of PDXScholar. Please contact us if we can make this document more accessible: pdxscholar@pdx.edu. 
Effects of HRU Size on PRMS Performance in 30 Western U.S. Basins

by

Madeline Olena Steele

A thesis submitted in partial fulfillment of the requirements for the degree of

\author{
Master of Science \\ in \\ Geography
}
Thesis Committee:
Heejun Chang, Chair Jiunn-Der Duh
David Garen

Portland State University

2013 
(C) 2013 Madeline Olena Steele 


\begin{abstract}
Semi-distributed hydrological models are often used for streamflow forecasting, hydrological climate change impact assessments, and other applications. In such models, basins are broken up into hydrologic response units (HRUs), which are assumed to have a relatively homogenous response to precipitation. HRUs are delineated in a variety of ways, and the procedure used may impact model performance. HRU delineation procedures have been researched, but it is still not clear how important these subdivision schemes are or which delineation methods are most effective. To start addressing this knowledge gap, this project investigated whether or not HRU size has a significant effect on streamflow simulation at the mouth of a watershed.
\end{abstract}

To test this, 30 gaged, relatively unimpaired western U.S. basins were each modeled with 6 HRU sets of different sizes using the Precipitation Runoff Modeling System (PRMS). To isolate size as a variable, HRUs were delineated using stream catchments. For each basin, streams were defined with 6 different threshold levels, producing HRUs of differing sizes. Nineteen model parameters were derived for each HRU using nationally consistent GIS datasets, and all other model parameters were left at default values. Climate inputs were derived from a national $4-\mathrm{km}^{2}$ gridded daily climate dataset.

After calibration, 4 goodness-of-fit metrics were calculated for daily streamflow for each HRU set. Uncalibrated model performance was generally poor for a variety of reasons, but comparison of the models was still informative. Results for the 30 basins across the 6 HRU size classes showed that HRU size did not significantly impact model performance across all basins. However, in basins that had less total precipitation and 
higher elevation, sensitivity of model performance to HRU subdivision levels was slightly greater, though not significantly so. Findings indicate that, in most basins, little subdivision may be required for good model performance, allowing for desirable simplicity and fewer degrees of freedom without sacrificing runoff simulation accuracy. 


\section{Acknowledgments}

I would like to thank Heejun Chang, my advisor, for his astute guidance and kind encouragement over the last three years. My other thesis committee members, David Garen and Jiunn-Der (Geoffrey) Duh, were also very generous with their time and energy throughout this process. Special thanks go to Il-Won Jung, who taught me a great deal about watershed modeling. I am very grateful to Joe Fusion for assisting me with scripting and for editing an early draft of this document. 


\section{Table of Contents}

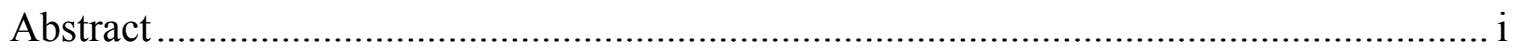

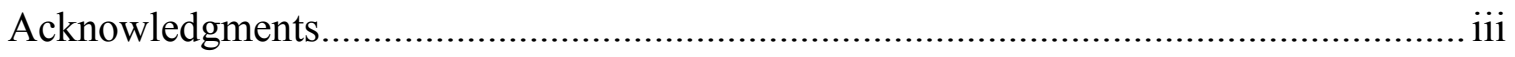

Table of Contents ................................................................................................ iv

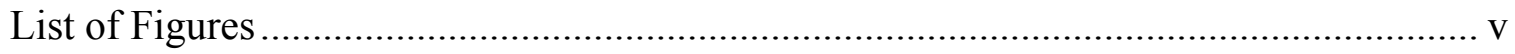

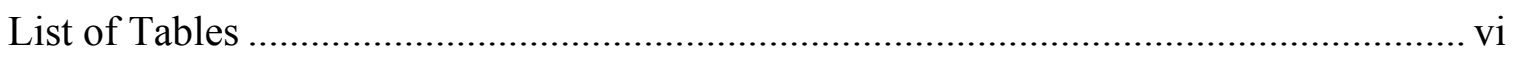

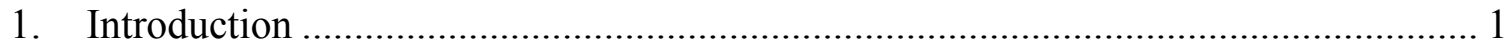

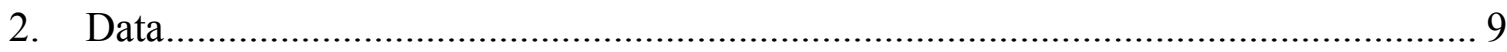

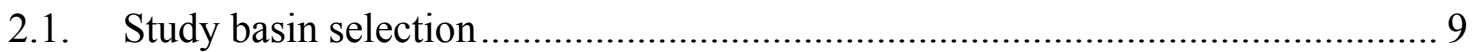

2.2. The Hydrologic Model - PRMS .................................................................. 14

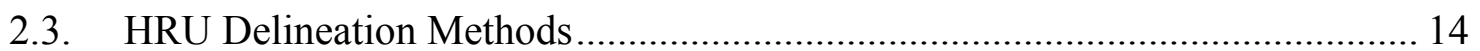

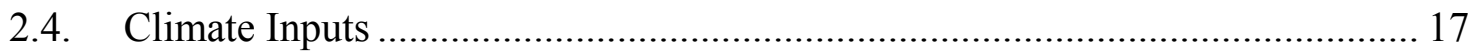

2.5. Model parameterization data and methods.................................................... 18

2.6. Model Performance Assessment .................................................................... 21

2.7. Geographic patterns in model performance ................................................ 22

2.8. Correlations among basin characteristics and range of goodness of fit scores .. 23

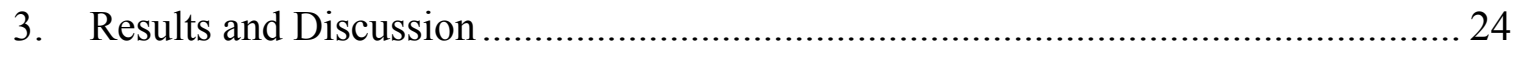

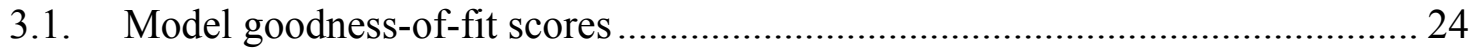

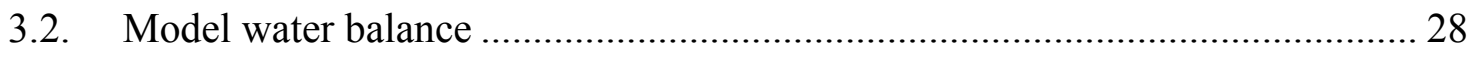

3.3. Monthly hydrographs for representative basins ......................................... 31

3.4. Geographic patterns in average model performance and range of model performances ....................................................................................... 39

3.5. Correlations between basin characteristics and range in goodness of fit scores by

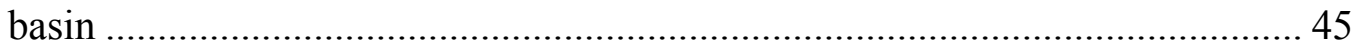

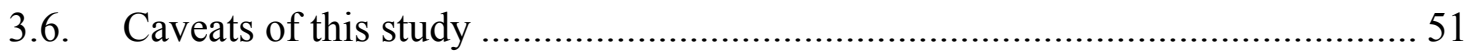

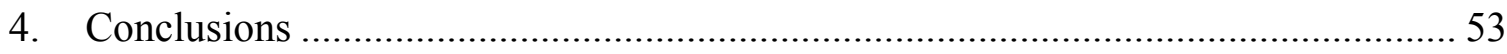

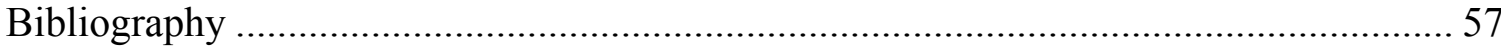

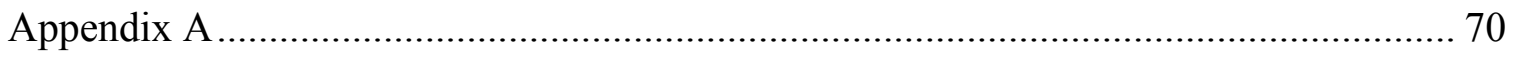

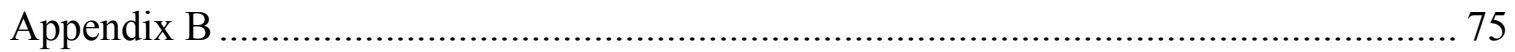




\section{List of Figures}

Figure 1. Basins modeled in this study, labeled with their USGS gage ID numbers. ...... 11

Figure 2. Example basin with 6 levels of HRU subdivision.......................................... 16

Figure 3. Correlation Coefficient ( $r$ ) for 6 HRU size classes for the period 10/1/1987-

9/30/2010 26

Figure 4. Nashe-Sutcliffe Efficiency (NSE) for 6 HRU size classes for the period $10 / 1 / 1987-9 / 30 / 2010$ 26

Figure 5. IoA for 6 HRU size classes for the period 10/1/1987-9/30/2010 .................... 27

Figure 6. PB for 6 HRU size classes for the period 10/1/1987-9/30/2010 ...................... 27

Figure 7. Basins with hydrographs shown below (Figures 8 through 13) ....................... 32

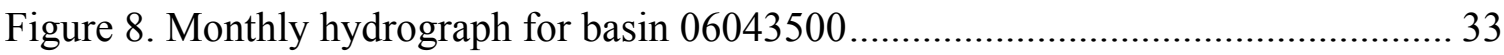

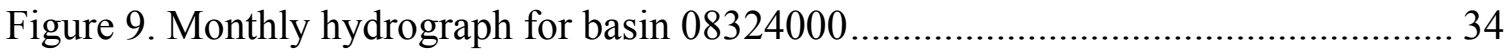

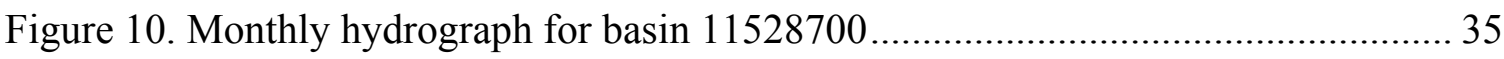

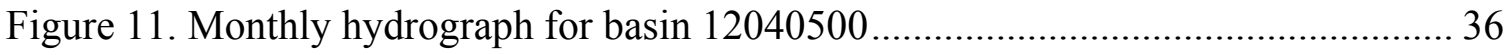

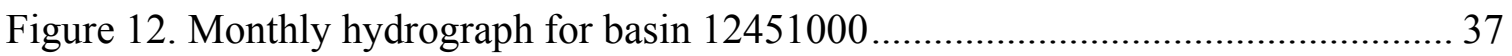

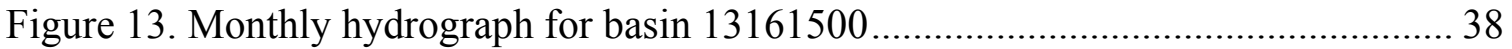

Figure 14. Average Correlation Coefficient ( $r$ ) among 6 HRU size classes by basin ...... 40

Figure 15. Average Nashe-Sutcliffe Efficiency (NSE) among 6 HRU size classes by

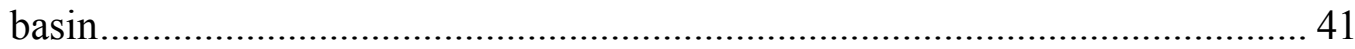

Figure 16. Average Percent Bias among 6 HRU size classes by basin ......................... 41

Figure 17. Range in Correlation Coefficient $(r)$ among 6 HRU size classes by basin ..... 43

Figure 18. Range in Nashe-Sutcliffe Efficiency (NSE) among 6 HRU size classes by

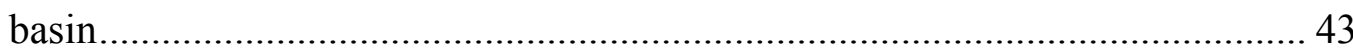

Figure 19. Correlation Coefficient $(r)$ for 10 driest basins, divided into 6 HRU size

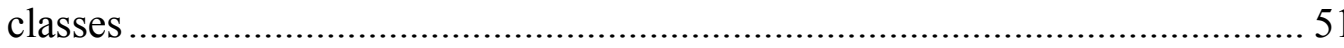




\section{List of Tables}

Table 1. Summary of studies on HRU size effects on streamflow simulation ................... 4

Table 2. Gages used in this study, and statistics about their basins from GAGES II

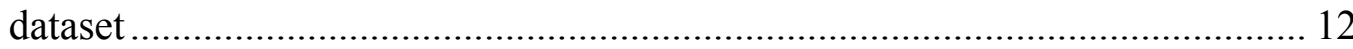

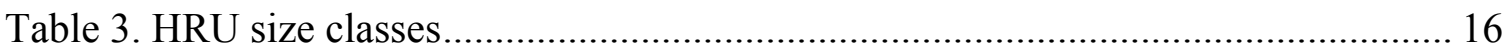

Table 4. PRMS parameters derived from GIS datasets. ............................................. 19

Table 5. GIS Datasets used to parameterize HRUs. ...................................................... 20

Table 6. Water balance summaries for 30 basins. ......................................................... 29

Table 7. Results of Moran's $I$ analysis for goodness of fit means and ranges. ................ 44

Table 8. Spearman's rank correlation coefficients between basin variables and ranges in model performance scores .......................................................................... 47 


\section{Introduction}

Hydrologic models are increasingly used to forecast streamflow, estimate climate change impacts, and improve understanding of hydrological processes. These models are typically classified on a scale of lumped to distributed; in lumped models, the basin is assumed to have a homogenous response to climatic inputs, and computations are averaged over the entire basin area. In distributed models, hydrologic calculations are made independently for each cell of the model (e.g., each 30-m land cover pixel). Semidistributed models are a compromise between these two extremes in which watersheds are sub-divided into a set of hydrological response units (HRUs). Many semi-distributed models have been developed, including the Precipitation Runoff Modeling System (PRMS), Soil and Water Assessment Tool (SWAT), Semi-distributed Land-Use Runoff Process (SLURP), the Hydrologic Engineering Center's Hydrologic Modeling System (HEC-HMS), the Cold Regions Hydrologic Model (CRHM), and others (Beckers et al., 2009). In such models, each HRU is assumed to have a homogenous response to climatic inputs. Depending on the method of HRU delineation, the size of these HRUs can vary widely, but it is not clear which level of subdivision, if any, is most appropriate for the majority of basins.

The question of optimizing HRU size is of practical importance to hydrological modelers as they create or revise watershed models. It also relates to the ongoing theoretical debate about the appropriate level of spatial discretization in hydrologic modeling (Beven, 1993). By manipulating the number of HRUs in a basin, a modeler controls where a model falls on the scale from lumped to fully distributed. Increasing 
distribution can improve a model's ability to capture local variability, and thus, at least theoretically, enhance overall model performance. It is generally thought that distributed models offer the most "realistic" representation of basin physical characteristics (Knight et al., 2001), and thus allow for better prediction of how a hydrologic system will behave with novel climate inputs (i.e., under climate change) (Beven, 2001). However, distributed models are much more complex and have more degrees of freedom. This, as Beven $(1993,2006)$ has observed, increases the model's equifinality, which is its ability to reach a particular end state from many differing sets of initial conditions. In other words, many different hydrologic parameter sets can each generate a similar, successful model performance. Distributed models also require more data, validation, and processing power (Jung et al., 2012; Surfleet et al., 2012). Thus, depending on the application, there may be an optimal HRU size that provides a compromise between lumped and distributed approaches, and model subdivision experiments could help identify it. Semi-distributed models such as PRMS are well suited for investigating these questions, because they can mimic a lumped model when a single HRU is used and a distributed model when numerous small HRUs are used.

Many studies have investigated the effects of subdivision level (i.e., number of HRUs) on semi-distributed model outcomes, including the simulation of streamflow (Cho et al., 2010; Norris and Haan, 1993; Wood et al., 1988), sediment levels (Bingner et al., 1997; FitzHugh and Mackay, 2000; Muleta et al., 2007), nutrient levels (Arabi et al., 2006; Jha et al., 2004), and extreme runoff (Kumar and Merwade, 2009). The current study focuses on subdivision's effects on daily streamflow simulation because of this variable's wide usage and practical implications for water resource management. 
Previous studies that explored this same issue using various semi-distributed watershed models have yielded conflicting findings. Many found that model results (as judged by various goodness-of-fit measures) improved with increasing subdivision (Lacroix, 1999; Norris and Haan, 1993; Wood et al., 1988; Zhang et al., 2004). Mamillapalli et al. (1996) divided a 4,300 $\mathrm{km}^{2}$ basin located in Texas into 9 different schemes with average subbasin sizes of $717,538,307,215,179,148,123,108$, and $79.6 \mathrm{~km}^{2}$ each. They found that smaller sizes yielded better results, but that these improvements plateaued after they reached an average size of $215 \mathrm{~km}^{2}$. By contrast, other studies, which modeled basins of highly varied sizes, have found that model performance was essentially insensitive to changes in the level of basin subdivision (Cho et al., 2010; FitzHugh and Mackay, 2000; Jha et al., 2004; Muleta et al., 2007; Nour et al., 2008; Tripathi et al., 2006; Wingfield, 2008). Also, in a SWAT study by Kumar and Merwade (2009) and in a PRMS study by Qi et al. (2009), increases in subdivision led to decreases in model performance. These studies and their essential findings are summarized in Table 1.

As Table 1 illustrates, basins of many different size ranges have been modeled in the literature. In these studies, the subdivision schemes, and often the study goals, are not consistent. Thus, these studies are not fully comparable, and though much work has been done, it is difficult to draw universal conclusions because of the specificity of each investigation. Further, various hydrologic models have been used, and these models are likely to differ in their sensitivity to subdivision.

For example, most of the SWAT studies (5 out of 7) found that flow simulation was not sensitive to subdivision, but only approximately half of the non-SWAT studies shared 
Table 1. Summary of studies on HRU size effects on streamflow simulation

\begin{tabular}{|c|c|c|c|c|c|c|c|}
\hline Study & $\begin{array}{l}\text { Hydrologic } \\
\text { Model }\end{array}$ & $\begin{array}{l}\text { No. of } \\
\text { Basin } \\
\text { s }\end{array}$ & Study Area & $\begin{array}{l}\text { Basin } \\
\text { Size } \\
\left(\mathbf{k m}^{2}\right)\end{array}$ & $\begin{array}{l}\text { Levels } \\
\text { of sub- } \\
\text { division }\end{array}$ & Subdivision scheme (avg. HRU size in km²) & $\begin{array}{l}\text { Did increased } \\
\text { subdivision lead to better } \\
\text { streamflow simulation? }\end{array}$ \\
\hline Wood et al., 1988 & TOPMODEL & 1 & $\begin{array}{l}\text { North } \\
\text { Carolina, USA }\end{array}$ & 17 & 4 & $5.67,0.89,0.46,0.20$ & yes \\
\hline $\begin{array}{l}\text { Norris and Haan, } \\
1993\end{array}$ & HEC-1 & 1 & $\begin{array}{l}\text { Oklahoma, } \\
\text { USA }\end{array}$ & 152.3 & 4 & $76.2,30.5,15.2,10.2$ & yes \\
\hline Mamillapalli, 1996 & SWAT & 1 & Texas, USA & 4,3004 & 9 & $\begin{array}{l}\text { 716.7, 537.5, 307.1, 215.0, 179.2, 148.3, 122.9, } \\
107.5,79.6\end{array}$ & yes, up to 215 km² \\
\hline Lacroix, 1999 & SLURP & 1 & $\begin{array}{l}\text { Yukon, } \\
\text { Canada }\end{array}$ & 183.3 & 21 & $\begin{array}{l}183.3,61.1,36.7,26.2,16.7,12.2,10.8,9.65,5.55 \\
2.38,1.13,0.60,0.44,0.41,0.35,0.32,0.30,0.27 \\
0.25,0.22,0.12\end{array}$ & yes \\
\hline $\begin{array}{l}\text { Fitzhugh and } \\
\text { Mackay, } 2000\end{array}$ & SWAT & 1 & $\begin{array}{l}\text { Wsconsin, } \\
\text { USA }\end{array}$ & 47.1 & 8 & $15.7,9.42,4.28,2.05,1.00,0.65,0.49,0.26$ & insensitive to subdivision \\
\hline Jha et al., 2004 & SWAT & 4 & Iowa, USA & $\begin{array}{l}1,929 \\
4,776 \\
10,829 \\
17,941\end{array}$ & 5 to 7 & $\begin{array}{l}\text { 385.8, 175.4, 113.5, 71.4, 55.1, 41.0, 36.4; } \\
\text { 1592.0, 434.2, 280.9, 176.9, 129.1, 101.6; } \\
\text { 3609.7, 1203.2, 637.0, 401.0, 292.7, 230.4; } \\
\text { 5980.3, 1993.4, 1196.1, 780.0, 512.6 }\end{array}$ & insensitive to subdivision \\
\hline Zhang et al., 2004 & SAC-SMA & 1 & $\begin{array}{l}\text { OKlahoma, } \\
\text { USA }\end{array}$ & 1,227 & 2 & $1227.0,153.4$ & yes \\
\hline $\begin{array}{l}\text { Tripathi et al., } \\
2006\end{array}$ & SWAT & 1 & India & 90.2 & 3 & $90.2,7.52,4.10$ & insensitive to subdivision \\
\hline Muleta et al., 2007 & SWAT & 1 & Illinois, USA & 133 & 6 & $14.8,6.05,1.77,1.13,0.61,0.38$ & insensitive to subdivision \\
\hline Nour et al., 2008 & ANN & 1 & $\begin{array}{l}\text { Alberta, } \\
\text { Canada }\end{array}$ & 15.62 & 4 & $15.6,3.12,2.23,1.42$ & insensitive to subdivision \\
\hline Wingfield, 2008 & HEC-HMS & 5 & Texas, USA & $\begin{array}{l}68.6 \\
9.9 \\
60.3 \\
18.4 \\
119.4\end{array}$ & 6 & $\begin{array}{l}22.9,13.7,9.80,6.86,4.57,2.29 \\
6.63,3.98,2.84,1.99,1.33,0.66 \\
20.1,12.1,8.61,6.03,4.02,2.01 \\
6.13,3.68,2.63,1.84,1.23,0.61 \\
39.8,23.9,17.1,11.9,7.96,3.98\end{array}$ & insensitive to subdivision \\
\hline
\end{tabular}

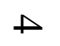




\begin{tabular}{|l|l|l|l|l|l|l|l|}
\hline \hline Study & $\begin{array}{l}\text { Hydrologic } \\
\text { Model }\end{array}$ & $\begin{array}{l}\text { No. of } \\
\text { Basin } \\
\mathbf{s}\end{array}$ & Study Area & $\begin{array}{l}\text { Basin } \\
\text { Size } \\
\mathbf{( k ^ { 2 } )}\end{array}$ & $\begin{array}{l}\text { Levels } \\
\text { of sub- } \\
\text { division }\end{array}$ & Subdivision scheme (avg. HRU size in km) & $\begin{array}{l}\text { Did increased } \\
\text { subdivision lead to better } \\
\text { streamflowv simulation? }\end{array}$ \\
\hline $\begin{array}{l}\text { Kumar and } \\
\text { Merwade, 2009 }\end{array}$ & SWAT & 2 & $\begin{array}{l}\text { Indiana, } \\
\text { Michigan, } \\
\text { Ohio; USA }\end{array}$ & $\begin{array}{l}2,800 ; \\
700\end{array}$ & 6 & $\begin{array}{l}280.0,233.3,116.7,77.8,48.3,28.9 ; \\
100.0,77.8,46.7,41.2,30.4,17.1 \\
\text { sub-basins, each with 2 HRU schemes }\end{array}$ & $\begin{array}{l}\text { no - increasing subdivision } \\
\text { decreased performance }\end{array}$ \\
\hline Qi et al., 2009 & PRMS & 1 & $\begin{array}{l}\text { North } \\
\text { Carolina, USA }\end{array}$ & 377 & 4 & $17.1,5.31,3.19,1.68$ & $\begin{array}{l}\text { no - increasing subdivision } \\
\text { decreased performance }\end{array}$ \\
\hline Cho et al., 2010 & SWAT & 1 & Georgia, USA & 15.7 & 9 & $5.23,1.43,0.92,0.54,0.45,0.29,0.16,0.09$ & insensitive to subdivision \\
\hline \hline
\end{tabular}


this finding. This is a very small sample size, but if it is true that SWAT has less sensitivity, it may relate to its unique, two-tiered subdivision scheme. In SWAT, a basin is first divided into sub-basins based on a critical source area (CSA). CSA is the minimum upstream drainage area required to define a stream channel; these channels are then used to create sub-basins. CSA is specified as a percentage of the total drainage area. Each sub-basin is further divided into HRUs based on land cover and soil types (Kumar and Merwade, 2009). Given this structure, a SWAT basin with few sub-basins can actually have many HRUs that capture spatial variability; this could make SWAT results of limited comparability to other semi-distributed models. SWAT also differs from other models in its general level of complexity; SWAT includes more parameters and input and output variables than many other semi-distributed models because it also models instream processes, water quality, and sediment transport (Daniel et al., 2011).

Thus, though SWAT is one of the most well studied models, its unique HRU structure and higher degree of complexity imply that findings from these studies may be of limited applicability to other semi-distributed models. This includes PRMS, which is the focus of the current investigation. PRMS was selected because it is commonly used for hydrological modeling around the world (Bae et al., 2008; Burlando and Rosso, 2002; Chang and Jung, 2010; Legesse et al., 2003; Qi et al., 2009), but there is a lack of clarity about how best to delineate HRUs for this model. To the author's knowledge, only Qi et al. (2009) has evaluated how HRU size affects model performance in PRMS. This study used four versions of a $377-\mathrm{km}^{2}$ basin in North Carolina. The versions had average HRU sizes of $17.1,5.3,3.2,1.7 \mathrm{~km}^{2}$, and were all parameterized using the GIS Weasel (Viger and Leavesley, 2007). The researchers evaluated each model using Nash-Sutcliffe 
Efficiency (NSE) and relative error (Er) at daily and monthly scales. They found that the version with an average HRU size of $17.1 \mathrm{~km}^{2}$ best simulated daily streamflow at the mouth of the basin. These results are interesting, but may only be relevant in that humid, temperate climatic region. A more thorough, multi-basin investigation of the impacts of HRU size in PRMS could provide more general results.

Although this brief review does not include all published investigations of the effect of model subdivision on streamflow simulation performance, it demonstrates that the relationship between HRU size and model performance is still unclear. Also, as Table 1 shows, most of these studies were conducted on only one basin each. Results from such studies may be strongly influenced by local variables, and it is not clear that their findings can be broadly applied. Further, each study used a unique combination of models, data inputs, HRU delineation methods, and calibration techniques, and direct comparison among them may not always be appropriate. Thus, the following questions remain unanswered: 1) Does HRU size impact PRMS performance? 2) If so, does one HRU size class perform better than others across a range of basins? 3) If not, how does the relationship between HRU size and model performance vary according to basin location and characteristics?

In order to answer these questions, thirty gaged western basins with essentially unimpaired flow conditions and of comparable size were modeled using PRMS. These basins were selected to maximize comparability while also obtaining a sample that was large enough to support statistical analysis. For each basin, HRUs were delineated at six size classes (including a fully lumped version), and model parameterization was 
automated and consistent for all models. The goodness of fit for each model was then computed for daily streamflow simulation. These goodness-of-fit metrics were then compared to basin characteristics that might mediate the relationships between HRU size and PRMS performance. The results will be most obviously relevant to PRMS, but should also be informative for researchers using other semi-distributed hydrological models, and can contribute to the longstanding debate about the level of discretization of hydrologic models. 


\section{Data and Methods}

\subsection{Study basin selection}

The study basins were selected from the GAGES (Geospatial Attributes of Gages for Evaluating Streamflow) II dataset, created by the U.S. Geological Survey (USGS). This is an update to the original GAGES dataset, described in Falcone et al. (2010). GAGES II includes GIS (Geographic Information System) data and classifications for 9,322 USGS stream gages throughout the U.S. The dataset was created to provide users with a detailed set of traits for a large number of gaged watersheds, and to identify basins in which the hydrologic system has been least disturbed by humans.

These relatively unimpaired basins, or "reference gages," were selected based on: (1) an index of anthropogenic influence in a basin derived from seven variables: density of major dams in the basin; basin change in reservoir storage from 1950-2009; basin percentage of streams that were coded artificial (canals, pipes, etc.); basin road density; distance from stream gage to closest significant pollution discharge site, county-level estimates of water withdrawals; and fragmentation of the basin's undeveloped land; (2) visual inspection of gage sites and their basins in Google Earth and topographic maps; and (3) information from Annual USGS Water Data Reports about human influences for the basin (Falcone et al., 2010). Basins for the current study were selected from these reference gages, because variability in model performance stemming from different levels of human interference would have made the basins less comparable.

From these reference datasets, only basins in the western U.S. were selected. This was done in part because the climate dataset utilized (described below) was only validated over the western U.S., though it covers all of the contiguous U.S. (Abatzoglou, 
2011). Focusing on the western states is also useful because these areas tend to be more sensitive to climate change due to the importance of the snowpack to spring and summer flows (Barnett et al., 2008), and thus good hydrological models are key in these areas. Excluding eastern basins also constrained the total number of basins to a manageable number. The basins were further constrained to a size range of 700 to $3,000 \mathrm{~km}^{2}$. Basins smaller than this were omitted because the minimum HRU size was identified as $4 \mathrm{~km}^{2}$ (as explained in the HRU delineation section below), and using small basins would not allow for multiple levels of increasing subdivision before reaching this HRU size limit. From these, any basins without a continuous flow record of at least 20 years were eliminated, leaving 30 total basins. The selected basins are shown in Figure 1, and are labeled with their USGS gage ID numbers. 


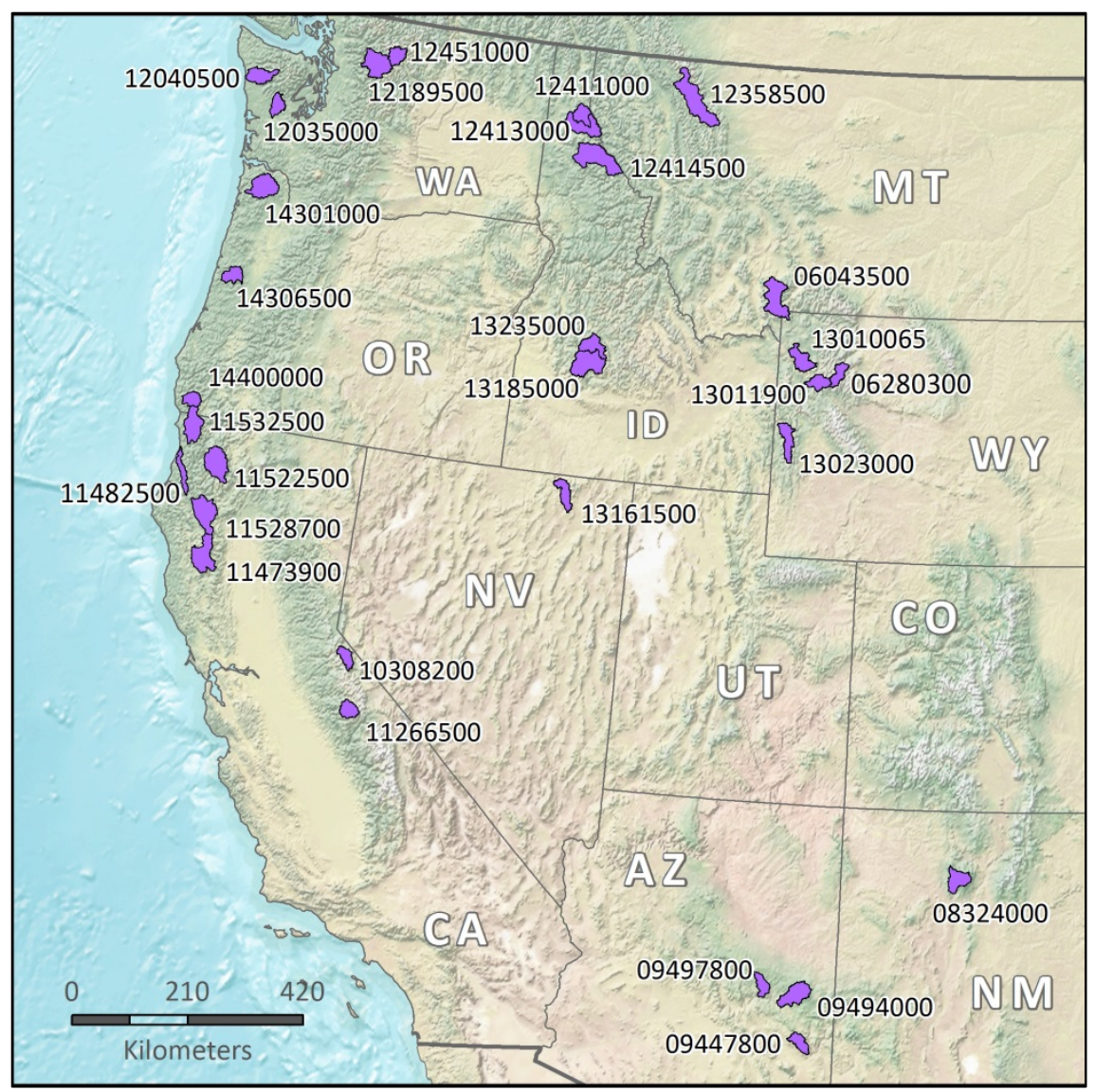

Figure 1. Basins modeled in this study, labeled with their USGS gage ID numbers.

According to the GAGES II classifications, 28 of the basins are in the "Western Mountains" aggregated ecoregion. That ecoregion was selected because its mountainous areas are more likely to be unimpaired than other ecoregions. The common ecoregion helps to make the basins more comparable. The two other basins, Bonita Creek near Morenci, AZ (09447800) and Bruneau River at Rowland, NV (13161500) were classified as "Xeric West." Table 2 reports gage numbers and names for the 30 basins, and provides select metrics for each. To maximize comparability, this study uses the longest possible period of recorded flow that is common to all 30 of these basins, which is 10/1/1985 through 9/30/2010. 
Table 2. Gages used in this study, and statistics about their basins from GAGES II dataset (Falcone et al., 2010)

\begin{tabular}{|c|c|c|c|c|c|c|c|c|}
\hline Gage ID & Gage Station Name & $\begin{array}{l}\text { Basin } \\
\text { area } \\
\left(\mathbf{k m}^{2}\right)\end{array}$ & $\begin{array}{l}\text { Basin mean } \\
\text { annual } \\
\text { precipitation } \\
\text { (cm) }\end{array}$ & $\begin{array}{l}\text { Basin mean } \\
\text { annual } \\
\text { temperature } \\
\left(C^{\circ}\right)\end{array}$ & $\begin{array}{l}\text { Basins } \\
\text { base } \\
\text { flow } \\
\text { index }\end{array}$ & $\begin{array}{l}\text { Basin } \\
\text { median } \\
\text { elevation } \\
(\mathrm{m})\end{array}$ & $\begin{array}{l}\text { Basin } \\
\text { mean } \\
\text { percent } \\
\text { slope }\end{array}$ & $\begin{array}{l}\text { Average } \\
\text { runoff } \\
\text { (mm/year) }\end{array}$ \\
\hline 06043500 & Gallatin River near Gallatin Gateway, MT & 2120.4 & 87.6 & 2.1 & 77.4 & 2409 & 28.2 & 230.6 \\
\hline 06280300 & SF Shoshone River near Valley, WY & 794.0 & 82.8 & 0.0 & 65.8 & 2953 & 44.7 & 245.7 \\
\hline 08324000 & Jemez River near Jemez, NM & 1208.0 & 63.5 & 6.3 & 54.3 & 2613 & 18.3 & 23.3 \\
\hline 09447800 & Bonita Creek near Morenci, AZ & 782.0 & 44.2 & 13.2 & 52.7 & 1575 & 15.9 & 41.0 \\
\hline 09494000 & White River near Fort Apache, AZ & 1628.2 & 73.9 & 8.4 & 56.1 & 2180 & 14.3 & 118.0 \\
\hline 09497800 & Cibecue Creek near Chysotile, AZ & 750.9 & 58.8 & 11.8 & 37.1 & 1715 & 19.4 & 55.9 \\
\hline 10308200 & EF Carson River below Markleeville C near Markleeville, CA & 716.4 & 98.0 & 4.8 & 68.4 & 2425 & 29.6 & 301.4 \\
\hline 11266500 & Merced River above Pohono Bridge near Yosemite, CA & 833.1 & 121.3 & 7.0 & 59.6 & 2561 & 30.0 & 692.6 \\
\hline 11473900 & MF Eel River near Dos Rios, CA & 1925.0 & 143.4 & 11.6 & 32.5 & 1104 & 26.4 & 710.6 \\
\hline 11482500 & Redwood Creek above Orick, CA & 718.0 & 212.9 & 11.1 & 42.7 & 525 & 28.1 & 1079.5 \\
\hline 11522500 & Salmon River above Somes Bar, CA & 1943.1 & 157.4 & 10.0 & 58.1 & 1292 & 44.1 & 863.0 \\
\hline 11528700 & SF Trinity River below Hyampom, CA & 1980.1 & 147.0 & 10.8 & 47.5 & 1125 & 28.2 & 631.2 \\
\hline 11532500 & Smith River near Crescent City, CA & 1578.0 & 282.6 & 11.0 & 46.3 & 731 & 36.9 & 2140.7 \\
\hline 12035000 & Satsop River near Satsop, WA & 769.9 & 305.2 & 9.7 & 51.2 & 136 & 16.1 & 2777.8 \\
\hline 12040500 & Queets River near Clearwater, WA & 1153.4 & 363.5 & 8.9 & 51.7 & 359 & 30.6 & 3733.1 \\
\hline 12189500 & Sauk River near Sauk, WA & 1855.3 & 276.6 & 6.2 & 59.2 & 1183 & 47.3 & 2134.5 \\
\hline 12358500 & MF Flathead River near West Glacier, MT & 2939.2 & 127.1 & 2.6 & 68.1 & 1751 & 40.4 & 876.8 \\
\hline 12411000 & NF Coeur D Alene River above Shoshone Ck near Prichard, ID & 867.5 & 122.6 & 5.7 & 65.8 & 1195 & 33.1 & 722.3 \\
\hline 12413000 & NF Coeur D Alene River at Enaville, ID & 2325.2 & 120.6 & 6.3 & 66.1 & 1155 & 34.8 & 721.4 \\
\hline 12414500 & St. Joe River at Calder, ID & 2679.0 & 127.7 & 5.7 & 67.2 & 1384 & 35.1 & 722.1 \\
\hline 12451000 & Stehekin River at Stehekin, WA & 830.6 & 173.2 & 5.2 & 64.2 & 1588 & 55.8 & 791.5 \\
\hline
\end{tabular}




\begin{tabular}{|c|c|c|c|c|c|c|c|c|}
\hline Gage ID & Gage Station Name & $\begin{array}{l}\text { Basin } \\
\text { area } \\
\left(\mathbf{k m}^{2}\right)\end{array}$ & $\begin{array}{l}\text { Basin mean } \\
\text { annual } \\
\text { precipitation } \\
\text { (cm) }\end{array}$ & $\begin{array}{l}\text { Basin mean } \\
\text { annual } \\
\text { temperature } \\
\left(C^{\circ}\right)\end{array}$ & $\begin{array}{l}\text { Basins } \\
\text { base } \\
\text { flow } \\
\text { index }\end{array}$ & $\begin{array}{l}\text { Basin } \\
\text { median } \\
\text { elevation } \\
\text { (m) }\end{array}$ & $\begin{array}{l}\text { Basin } \\
\text { mean } \\
\text { percent } \\
\text { slope }\end{array}$ & $\begin{array}{l}\text { Average } \\
\text { runoff } \\
\text { (mmlyear) }\end{array}$ \\
\hline 13010065 & Snake River above Jackson Lake at Flagg Ranch, WY & 1222.3 & 109.5 & 0.4 & 78.4 & 2492 & 13.7 & 615.7 \\
\hline 13011900 & Buffalo Fork above Lava Creek near Moran, WY & 851.8 & 96.0 & 0.4 & 70.1 & 2753 & 24.0 & 612.8 \\
\hline 13023000 & Greys River above Reservoir near Alpine, WY & 1161.9 & 81.1 & 1.4 & 77.1 & 2452 & 30.4 & 509.4 \\
\hline 13161500 & Bruneau River at Rowand, NV & 986.1 & 44.5 & 4.5 & 66.8 & 2010 & 20.2 & 48.8 \\
\hline 13185000 & Boise River near Tuin Springs, ID & 2154.4 & 92.8 & 4.6 & 74.3 & 1905 & 36.5 & 290.5 \\
\hline 13235000 & SF Payette River at Lowman, ID & 1163.2 & 101.2 & 3.6 & 74.6 & 2115 & 39.9 & 664.6 \\
\hline 14301000 & Nehalem River near Foss, OR & 1743.5 & 242.7 & 9.4 & 49.5 & 322 & 19.5 & 1394.2 \\
\hline 14306500 & Alsea River near Tidewater, OR & 857.2 & 210.9 & 11.6 & 43.3 & 290 & 27.4 & 1511.5 \\
\hline
\end{tabular}




\subsection{The Hydrologic Model - PRMS}

PRMS is a semi-distributed, deterministic, physically-based surface runoff model developed and regularly improved by the USGS (Leavesley et al., 1983; Leavesley and Stannard, 1995; Markstrom et al., 2005). This model has been used in climate change impact assessments around the world (Bae et al., 2008; Burlando and Rosso, 2002; Chang and Jung, 2010; Jung and Chang, 2011; Qi et al., 2009), for groundwater recharge estimation (Hart et al., 2009; Smerdon et al., 2009), for simulating natural discharge in a dammed basin (Ely and Risley, 2001), and more. PRMS computes a daily water balance for each HRU and then sums the water and energy balances, weighted by each HRU's relative area, to derive daily basin output values for flow, soil moisture, evapotranspiration (ET), and other variables (Hay et al., 2009). PRMS was recently modified to accept individual climate input files for each HRU (USGS, 2012). Previously, distribution of climate inputs (typically weather station data) to HRUs occurred within the model using one of several available modules. This new functionality makes it simpler to force PRMS with gridded climate datasets like the one used in this study (described below).

\subsection{HRU Delineation Methods}

In PRMS, HRUs can be delineated in a wide variety of ways. The primary objectives in delineation for this study were to keep basins comparable, and to isolate HRU size as a variable as much as was possible. To accomplish this, a simple catchment-based delineation approach was conducted with a custom ArcPy script (ESRI, 2012). Soil, Land Use/Land Cover (LULC), and other GIS datasets are often used in HRU delineation (e.g., Chang and Jung, 2010), but such methods would produce HRUs of widely varying size, 
depending on the variability of each layer in each basin. Thus, only topography was considered when delineating HRUs in the current study.

First, for each basin, multiple sets of stream networks of increasing complexity were generated from a 10-m DEM. Complexity of the stream networks was controlled by manipulating the number of cells that must be upstream of a given cell for it to be classified as a stream cell. This stream threshold is equivalent to the CSA parameter that has been used to control HRU size in similar studies with SWAT (Cho et al., 2010; FitzHugh and Mackay, 2000; Kumar and Merwade, 2009; Muleta et al., 2007).

Once these stream networks were defined, an HRU was created for each unique stream segment, and HRUs smaller than $4 \mathrm{~km}^{2}$ were merged into the neighboring HRU with which they shared the longest border. Four $\mathrm{km}^{2}$ was the cutoff because that was the resolution of the climate input grid. Given that climatic inputs are a major, if not the primary, determinant of model outputs, little would be gained by adding subdivisions finer than the resolution of climatic inputs. This is a larger cutoff than was used in some previous research; a few studies identified an optimal HRU size of as small as $1 \mathrm{~km}^{2}$ (Lacroix, 1999; Song and James, 1992; Wood et al., 1988). This study did not consider HRUs this small, which may be a limitation.

From the various stream threshold values, five final values were selected because they provided a satisfactory range of HRU sizes across all 30 basins. These threshold values were $80,000,100,000,200,000,400,000$, and 600,000 upstream cells. Additionally, a fully lumped model (1 HRU) was prepared for each basin, giving a total of six models of varying HRU size per basin, for a total of 150 models. Table 3 provides 
a summary of the HRU size classes, as well as the size class numbering scheme that will be used in the remainder of this paper. Figure 2 depicts the 6 HRU sets for an example basin.

Table 3. HRU characteristics by size classes

\begin{tabular}{|c|c|c|c|c|c|}
\hline \hline $\begin{array}{c}\text { HRU Size Class } \\
\text { Number }\end{array}$ & $\begin{array}{c}\text { Stream Definition } \\
\text { Threshold }\end{array}$ & $\begin{array}{c}\text { Median no. } \\
\text { HRUs }\end{array}$ & $\begin{array}{c}\text { Mean no. } \\
\text { HRUs }\end{array}$ & $\begin{array}{c}\text { Std. dev. } \\
\text { no. HRUs }\end{array}$ & $\begin{array}{c}\text { Avg. HRU size } \\
\left(\mathbf{k m}^{2}\right)\end{array}$ \\
\hline \hline 1 & Dissolve (1 HRU) & 1 & 1 & 0.0 & 1374.7 \\
\hline 2 & 600,000 & 10 & 10.9 & 6.0 & 144.2 \\
\hline 3 & 400,000 & 13 & 16.1 & 8.9 & 100.1 \\
\hline 4 & 200,000 & 25 & 31.6 & 18.1 & 46.7 \\
\hline 5 & 100,000 & 48.5 & 58.1 & 30.1 & 24.8 \\
\hline 6 & 80,000 & 78 & 85.2 & 45.2 & 16.9 \\
\hline
\end{tabular}

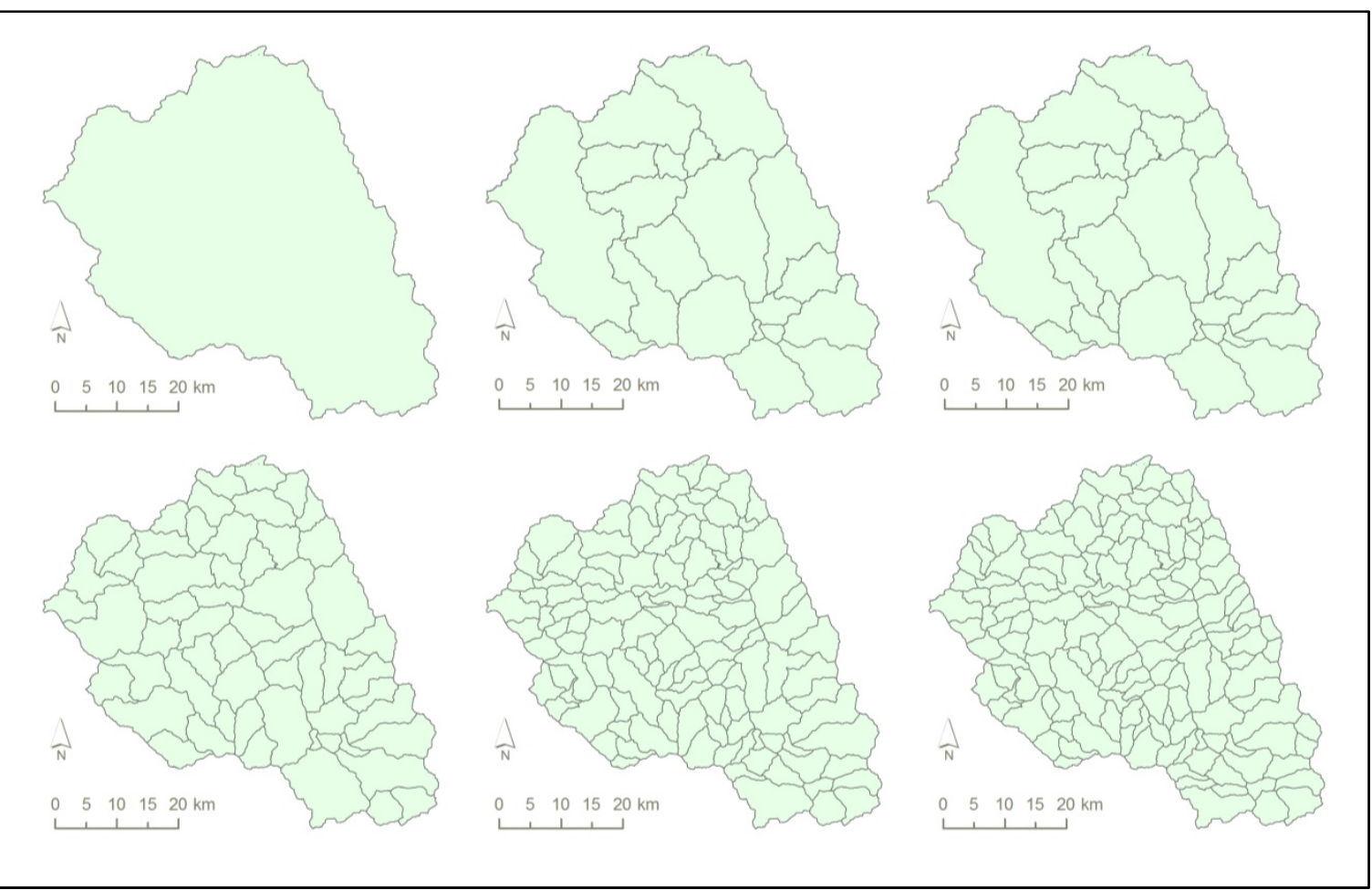

Figure 2. Example basin with six levels of HRU subdivision (North Fork Coeur d'Alene River at Enaville, ID, Gage No. 12413000) 


\subsection{Climate Inputs}

In order to model the basins as consistently as possible, this study employed a high resolution, gridded surface meteorological dataset prepared by Dr. John Abatzoglou of the University of Idaho (Abatzoglou, 2011). This dataset combines the spatial completeness of $4 \mathrm{~km}^{2}$ gridded climatic data with the temporal resolution of regionalscale analysis and daily measurements from NLDAS-2 (North American Land Data Assimilation System) for the contiguous U.S. from 1979-2011.

The climate dataset was validated against a large network of weather stations, and showed skill similar to datasets derived from interpolation of station observations (Abatzoglou, 2011). However, there was geographic variability in this skill. Precipitation, a critical variable in hydrological modeling, showed the strongest correlations to test datasets ( $r>0.85$, based on daily values) on the western, windward sides of the Cascades and the Sierra Nevada during the cool, rainy season. In these areas, most of the winter precipitation is delivered by synoptic-scale frontal systems, which tend to be homogenous over large areas. Convective processes, by contrast, are less spatially predictable, and are more common in areas east of the Cascades and the Sierra Nevada, especially in the Rockies and the Great Basin. These regions had lower correlations to test datasets on average (Abatzoglou, 2011).

Also relevant to the current study is the fact that snow-dominated areas often showed strong positive biases when compared to the test datasets. Abatzoglou (2011) argues that this may be because the test snow data were gathered by un-winterized automatic gages, which under-report solid precipitation. 
The climate dataset includes daily or sub-daily values for precipitation (PRCP), maximum temperature (TMAX), minimum temperature (TMIN), humidity (maximum and minimum relative humidity and specific humidity), surface downward shortwave radiation (daily mean) (SRAD), and wind velocity (daily mean). Only PRCP, TMAX, TMIN, and SRAD were used in the current study, because PRMS does not take humidity or wind velocity as climatic inputs. Daily time series for PRCP, TMAX, and TMIN were created by intersecting the 180 HRU sets ( 6 per basin) with the climate grid. Areaweighted averages of the time series grid cells that intersected each HRU were calculated, and then used as climate forcing data for PRMS.

\subsection{Model parameterization data and methods}

Many PRMS parameters can be derived for each HRU using GIS data layers. All parameters derived for the current study are listed in Table 4, and Table 5 provides the resolution and source of each GIS dataset. The methods used to derive parameters were essentially identical to those used by the GIS Weasel, a program for delineating and parameterizing HRUs for PRMS. These methods are fully described in the GIS Weasel's user manual (Viger and Leavesley, 2007). Some minor modifications were necessary because this study uses different input datasets than the GIS Weasel. Specifically, the LULC remap tables used to calculate parameters such as summer vegetation density (Viger and Leavesley, 2007) were altered to work with the National Land Cover Database (NLCD) (Homer et al., 2007) dataset by lumping the GIS Weasel's more numerous vegetation classes together. The coefficients for the NLCD classes were calculated by averaging the coefficients of all the GIS Weasel classes that were lumped 
into each one. Also, all methods were translated from Arc Macro Language (AML) into

ArcGIS ModelBuilder models and ArcPy scripts.

Table 4. PRMS parameters derived from GIS datasets. Dataset resolutions and sources are provided in Table 5.

\begin{tabular}{|l|l|l|}
\hline \hline Name & Description & GIS Dataset \\
\hline cov_type & $\begin{array}{l}\text { Vegetation cover type for each HRU (bare, } \\
\text { grass, shrubs, trees) }\end{array}$ & $\begin{array}{l}\text { National Land Cover Database (NLCD) 2001 } \\
\text { Land Cover }\end{array}$ \\
\hline covden_sum & $\begin{array}{l}\text { Summer vegetation cover density for each } \\
\text { HRU }\end{array}$ & NLCD 2001 Land Cover \\
\hline covden_win & $\begin{array}{l}\text { Winter vegetation cover density for each } \\
\text { HRU }\end{array}$ & NLCD 2001 Land Cover \\
\hline hru_aspect & Mean aspect of each HRU & USGS 10-m DEM \\
\hline hru_elev & Mean elevation of each HRU & USGS 10-m DEM \\
\hline hru_lat & Latitude of each HRU & -- \\
\hline hru_percent_imperv & $\begin{array}{l}\text { Proportion of each HRU area that is } \\
\text { impervious }\end{array}$ & NLCD 2001 Percent Developed Impervious \\
\hline hru_slope & Mean slope of each HRU & USGS 10-m DEM \\
\hline jh_coef_hru & $\begin{array}{l}\text { Air temperature coefficient used in Jensen- } \\
\text { Haise PET computations for each HRU. }\end{array}$ & NLCD 2001 Land Cover \\
\hline rad_trncf & $\begin{array}{l}\text { Transmission coefficient for short-wave } \\
\text { radiation through the winter vegetation } \\
\text { canopy }\end{array}$ & NLCD 2001 Land Cover \\
\hline snow_intcp & $\begin{array}{l}\text { Snow interception storage capacity for each } \\
\text { HRU }\end{array}$ & NLCD 2001 Land Cover \\
\hline snow_intcp & $\begin{array}{l}\text { Snow interception storage capacity for the } \\
\text { major vegetation type in each HRU }\end{array}$ & NLCD 2001 Land Cover \\
\hline soil_moist_max & $\begin{array}{l}\text { Maximum available water holding capacity } \\
\text { of soil profile for each HRU }\end{array}$ & $\begin{array}{l}\text { U.S. General Soil Map, GIS Weasel Data Bin, } \\
\text { NLCD 2001 Land Cover }\end{array}$ \\
\hline soil_rechr_max & $\begin{array}{l}\text { Maximum value for soil recharge zone for } \\
\text { each HRU } \\
\text { HRU soil type (sand, clay, or loam) }\end{array}$ & $\begin{array}{l}\text { U.S. General Soil Map, GIS Weasel Data Bin, } \\
\text { NLCD 2001 Land Cover }\end{array}$ \\
\hline soil_type & $\begin{array}{l}\text { Summer rain interception storage capacity } \\
\text { for each HRU }\end{array}$ & NLCD 2001 Land Cover \\
\hline srain_intcp & $\begin{array}{l}\text { Adjustment to max. temp. for each HRU } \\
\text { based on slope and aspect }\end{array}$ & $\begin{array}{l}\text { USGS 10-m DEM } \\
\text { based on slope and aspect }\end{array}$ \\
\hline tmax_adj & $\begin{array}{l}\text { Winter rain interception storage capacity for } \\
\text { each HRU }\end{array}$ & NLCD 2001 Land Cover \\
\hline tmin_adj & & USGS 10-m DEM \\
\hline wrain_intcp & & \\
\hline \hline
\end{tabular}

Most of the GIS datasets used for parameterization have full coverage for the contiguous U.S. (e.g., LULC, DEM), but finding spatially complete soil data was more challenging. The General Soil Map of the U.S. (USDA, n.d.), also known as STATSGO 
(State Soil Geographic Database) 2, has national coverage, but not for all variables. To obtain soil texture values for all basins, raster layers derived by Kern (2010) that correct inconsistencies and fill gaps in STATSGO were used. Rock depth values, used in calculating the parameters soil_moist_max and soil_rechr_max, were obtained from the GIS Weasel data bin layers. These layers were made by resampling STATSGO data to a 1-km pixel resolution (Viger and Leavesley, 2007).

Table 5. GIS Datasets used to parameterize HRUs.

\begin{tabular}{|l|l|l|}
\hline \hline Data Set & Resolution & Source \\
\hline \hline USGS 10-m DEM & $10-m$ pixels & Gesch et al., 2002 \\
\hline NLCD 2001 Land Cover & $30-\mathrm{m}$ pixels & Homer et al., 2007 \\
\hline $\begin{array}{l}\text { NLCD 2001 Percent } \\
\text { Impervious }\end{array}$ & $30-\mathrm{m}$ pixels & Homer et al., 2007 \\
\hline U.S. General Soil Map & $\begin{array}{l}\text { Digitized from 1:250,000 topographic quadrangles; } \\
\text { minimum map unit size of 2,500 acres }\end{array}$ & USDA-NRCS, n.d. \\
\hline $\begin{array}{l}\text { Soil texture layers from } \\
\text { Conservation Biology Institute }\end{array}$ & $800-\mathrm{m}$ pixels & Kern, 2010 \\
\hline $\begin{array}{l}\text { GIS Weasel Data Bin soil } \\
\text { layers }\end{array}$ & 1-km pixels & Viger and Leavesley, 2007 \\
\hline \hline
\end{tabular}

After parameterization, each model was run with no calibration. All parameters not listed in Table 4 were left at PRMS default value. Fifty-six total parameters were left at default values. Calibration was a part of the initial study design, but was not conducted due largely to time constraints. Each of the 180 models would have taken 1 to 3 days to calibrate, and even with multiple instances running at once on a Linux server, this would have been a prohibitively slow process. Arguably, however, leaving the models uncalibrated ensures consistency, because the Shuffled Complex Evolution (SCE) method (Duan et al., 1994) that would have been used would have introduced stochasticity to the parameter sets. Thus, for some models, a particular size class might 
appear to perform better through chance alone due to the near-inevitability of equifinality in complex hydrological models (Beven, 2006). Leaving the models uncalibrated makes the scores poorer, but may make cross-comparison of scores more robust. It is an untested assumption of this study that HRU size sensitivity patterns observed in poorly performing uncalibrated basins are relevant to calibrated, better performing models.

\subsection{Model Performance Assessment}

After models were parameterized and run for the period 10/1/1985 to 9/30/2010, the resulting daily time series of simulated streamflow were compared to measured streamflow using four goodness-of-fit metrics. These were the NSE score (Nash and Sutcliffe, 1970), which can range from - $-\infty$ to 1 , with 1 indicating perfect agreement; the Index of Agreement (IoA) (Willmott, 1981), which varies between 0 and 1, with 1 indicating perfect agreement; Pearson's Correlation Coefficient ( $r$ ), which ranges from -1 to 1 , with 1 indicating perfect agreement; and Percent Bias (PB), which has an optimal value of $0 \%$. These values were calculated for the period $10 / 1 / 1987$ to $9 / 30 / 2010$; the first two years were considered as a warm up period and discarded in scoring.

It is key to stress that this study was not designed to attain the best model performance, but rather, to ensure comparability of the models. Since the 6 models for each basin differ only in the number of HRUs, if there are differences among the scores, even if they are all poor, it is likely caused by HRU size.

Once all of these scores were calculated, the models were grouped by HRU size classes. For each HRU size class group, there were 30 total basins. The statistical distributions of these 6 groups of 30 were compared using a Kruskal-Wallis one-way 
ANOVA (Analysis of Variance) (Kruskal and Wallis, 1952) in SPSS version 21 (IBM Corp., 2011). This non-parametric statistic was selected because most of the variables in question had non-normal distributions.

To provide better understanding of the sources of error in various basins, a summary water balance was calculated for each basin for the period 10/1/1985 to 9/30/2010. Hydrographs were also prepared for six basins with varying total percent bias. A water balance table and hydrographs can help indicate whether a model might perform well after automatic calibration, or whether there is a more fundamental problem with the climate inputs that could not be easily resolved by calibration. This information could be used to help select calibration parameters or to eliminate problematic basins in a possible extension of this study.

\subsection{Geographic patterns in model performance}

Geographic patterns in model performance were visually inspected by creating a series of choropleth maps that showed average performance as well as range in performance for each basin. To test whether the patterns suggested by this visual inspection were statistically significant, Moran's $I$ was calculated for the means and ranges of the four goodness of fit scores using Open GeoDa (Anselin et al., 2006). Moran's $I$ is a commonly used measure of spatial autocorrelation that can range from -1 to 1 . When its value approaches 1 , the data are clustered (positive spatial autocorrelation), and when it approaches -1, they are dispersed (negative spatial aucocorrelation). Basin centroids were used in the calculations, and the weights file was based on the 5 nearest neighbors of each. For each statistic, a pseudo-significance ( $p$-value) was generated by 
creating 999 random arrangements of the variable values, and comparing the observed value to that distribution.

\subsection{Correlations among basin characteristics and range of goodness of fit scores}

To find whether goodness-of-fit scores were related to particular basin attributes, the scores were compared to numerous basin statistics included in the GAGES II dataset. First, the range for each goodness-of-fit score type (NSE, IoA, PB, r) across all six size classes was calculated for each basin. These four goodness-of-fit range numbers provide an indication of the sensitivity of a basin to variation in HRU size. These numbers were then compared to a large set of GAGES II variables that were judged to be hydrologically important in the study basins (listed in Appendix A). This comparison was done by finding Spearman's rank-order correlations between the goodness-of-fit range numbers and the basin statistics, pairwise, in SPSS. This non-parametric statistic was used because many of the input variables have non-normal distributions, making parametric statistics inappropriate with extensive normalization.

A strong correlation between a certain variable and a goodness-of-fit range score could indicate that HRU size was of greater important in certain types of basins. To aid in interpretation of these results, the list of basin characteristics was correlated against itself, pairwise. For example, the correlation of precipitation and baseflow index was found, as was the correlation of median elevation to percent forested. 


\section{Results and Discussion}

\subsection{Model goodness-of-fit scores}

As was explained in the introduction, the goal of the study was not to mass-produce accurate watershed models, but to create sets of models for each basin that varied only in HRU size, and which could be compared. Inter-basin comparability was also a primary goal. Model scores could be improved with calibration, or through careful selection of the best climate and GIS inputs for each area. However, this study was designed to ensure model comparability above other factors; as such, consistency of development was considered more important than the performance of individual models. The key assumption made here is that variation in these scores is meaningful, not random, though they are poor, and that it can provide information that is relevant to more accurate, calibrated, individually prepared models.

Figures 3 through 6 display the model performance results for the total modeled period as boxplots. In these figures, each boxplot represents 30 performance scores (one per basin) for one of the HRU size classes described in Table 4. All scores are provided in Appendix B. The figures clearly indicate that the distribution of model performance scores is remarkably similar across all 6 HRU size classes, for all 4 goodness of fit metrics. This indicates that no HRU size class leads to generally better model performance than any other.

To confirm this, Kruskal-Wallis one-way ANOVA non-parametric statistical tests were used to compare the distributions of each size class. For all 4 goodness of fit metrics, the null hypothesis, which was that the distributions were the same across all size 
classes, could not be rejected. This provides further evidence that, on average, variation in model subdivision does not have a significant impact on model performance. These results are consistent with those from many other studies (Table 1), and in this study, statistical tests confirm these results. The results thus provide further support for the contention that model subdivision is not an especially critical aspect of semi-distributed model development. Further, when taken with the other studies, these findings suggest that there is no clear "one HRU-size fits all" approach to watershed model subdivision.

These figures also show that the performance of most models was quite poor. These uncalibrated models would not be appropriate for forecasting stream flow levels or estimating climate change impacts. NSE scores are very poor, and PB scores indicate that for most basins, flow was over-predicted, likely due to underestimation of evapotranspiration or overestimation of precipitation input data.

For NSE (Figure 4), the boxplots show that there were two basins where model performance is particularly poor. For PB (Figure 6), however, the worst performance is in another basin. This illustrates that hydrological model performance assessments are sensitive to the goodness-of-fit metrics employed. 


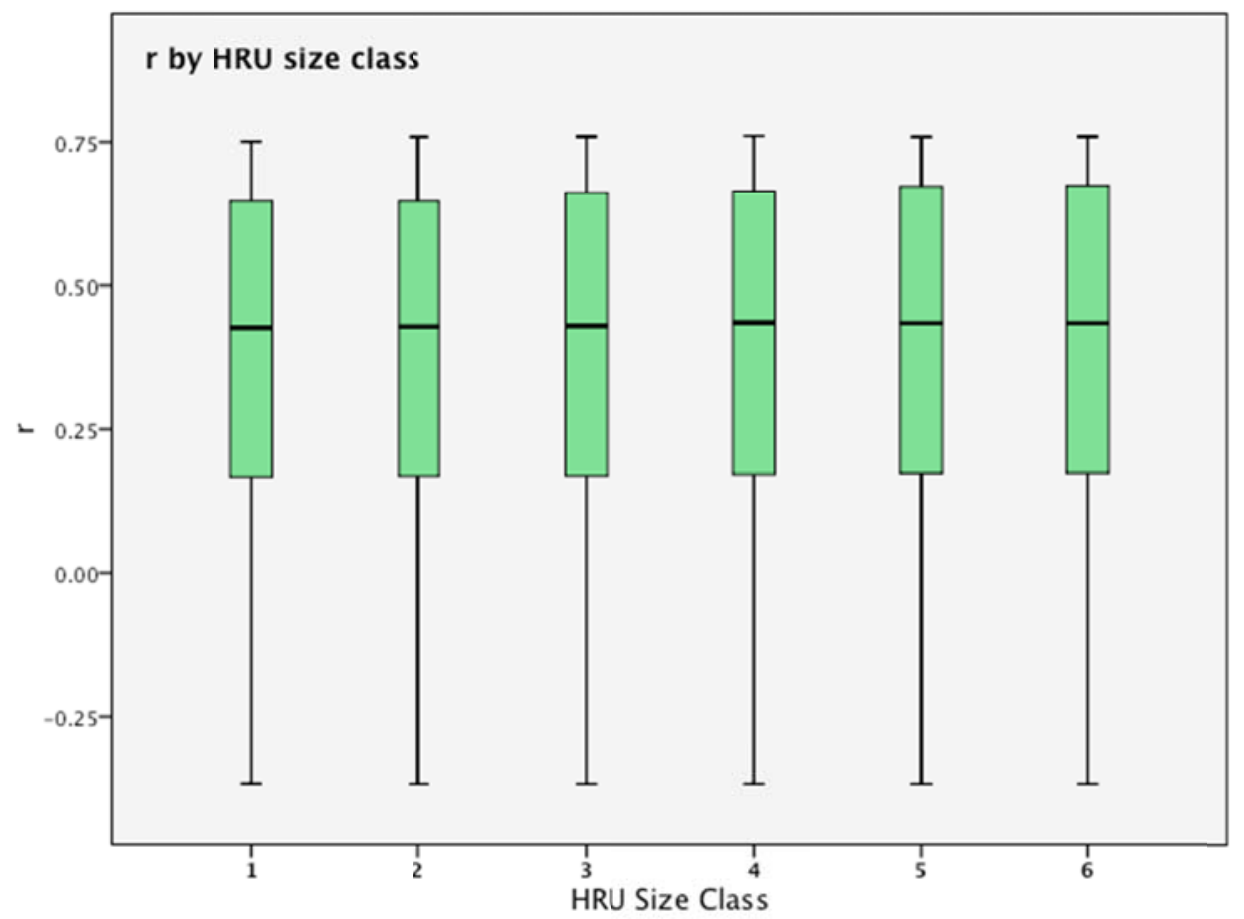

Figure 3. Correlation Coefficient ( $r$ ) for 6 HRU size classes for the period 10/1/1987-9/30/2010. The box length is the interquartile range.

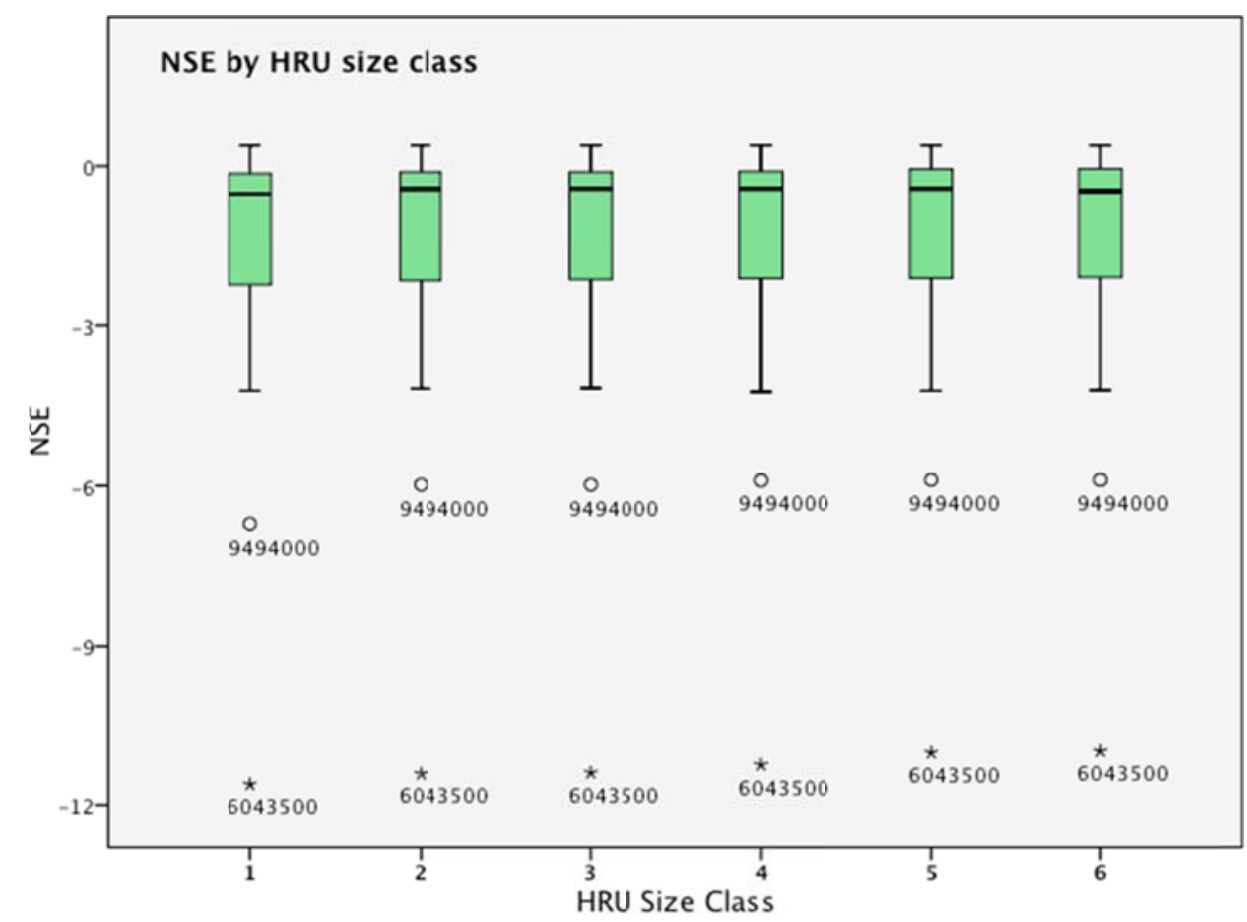

Figure 4. Nashe-Sutcliffe Efficiency (NSE) for 6 HRU size classes for the period 10/1/1987-9/30/2010. Open circles represent outliers, which have values between 1.5 and 3 box lengths from the edge of the box. Stars are extreme cases, which have values that are more than 3 box lengths from the edge of the box. The box length is the interquartile range. 


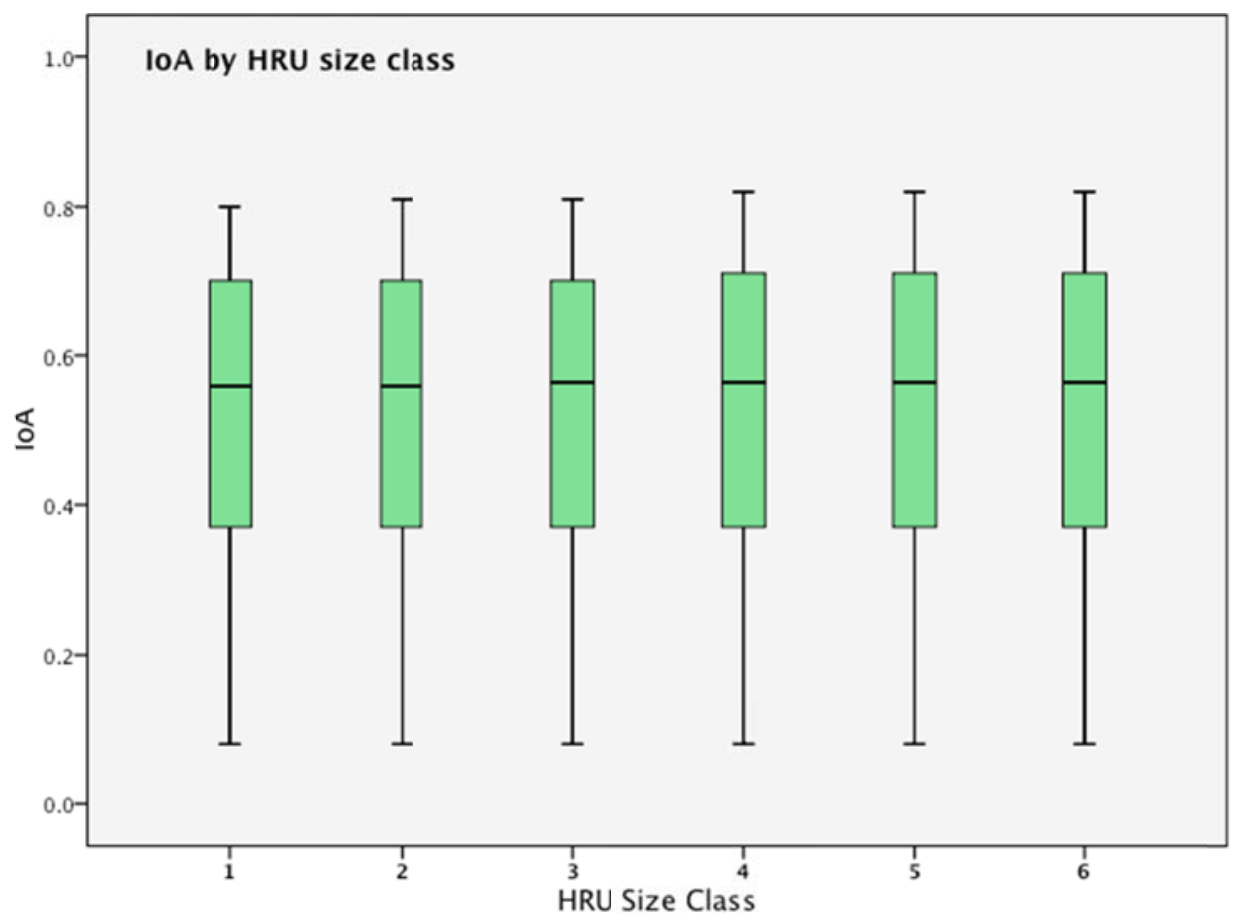

Figure 5. Index of agreement for $6 \mathrm{HRU}$ size classes for the period 10/1/1987-9/30/2010. The box length is the interquartile range.

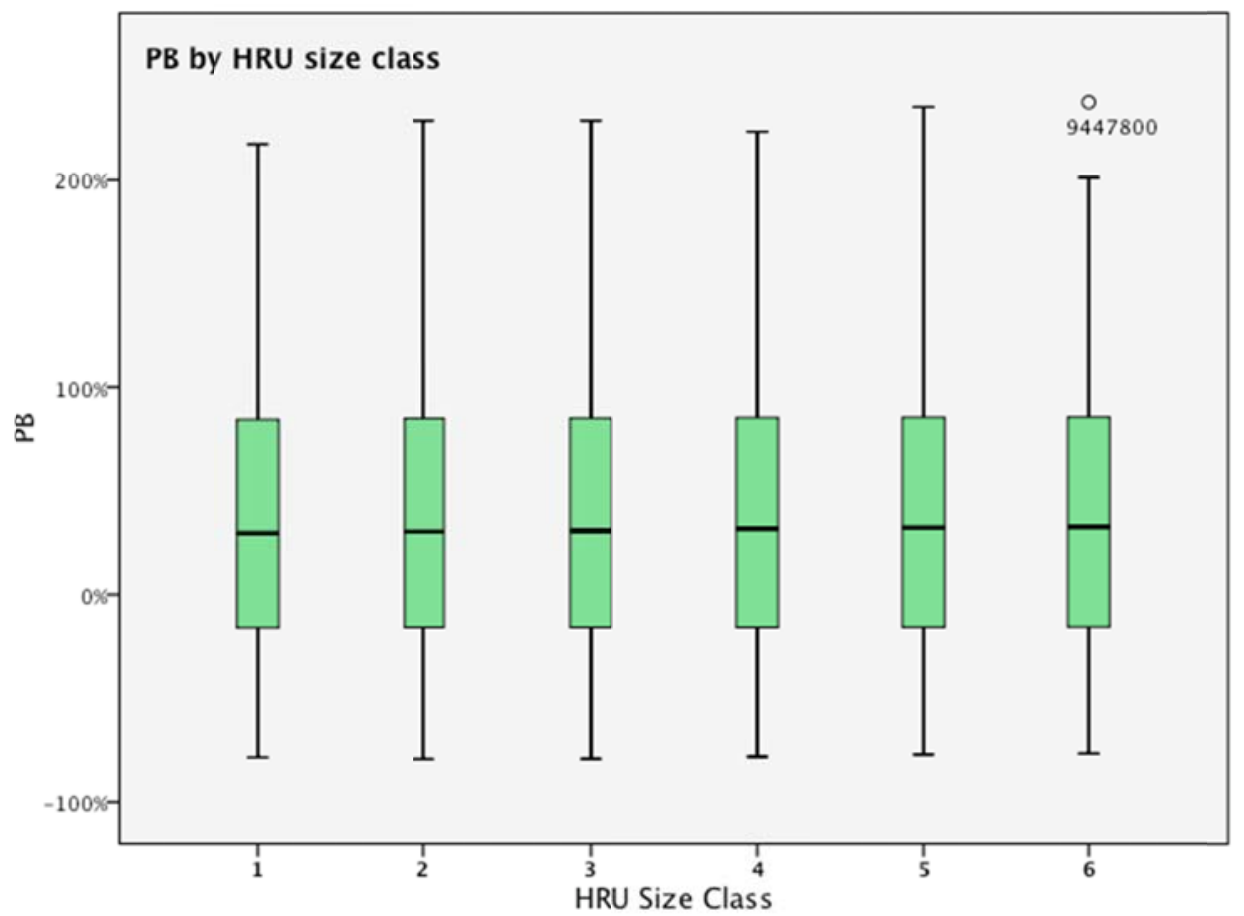

Figure 6. Percent Bias for 6 HRU size classes for the period 10/1/1987-9/30/2010. Open circles represent outliers with values between 1.5 and 3 box lengths from the edge of the box. The box length is the interquartile range. 


\subsection{Model water balance}

To provide some insight into why the goodness-of-fit scores were so poor on average, and to guide calibration efforts in a possible extension of this study, the average annual water balance from 10/1/1987 to 9/30/2010 was calculated for each model. Table 6 shows these average annual water balances for only one HRU size class (size class 4) for each basin. In each basin, balances were very similar for each of the 6 classes, and so displaying one size class is adequate. As shown in Table 6, precipitation is the sum of the climate grid time series inputs, and measured runoff is the depth sum from the USGS gage flow record. Evapotranspiration and simulated runoff are calculated in PRMS. Percent Bias is the percent error between measured and simulated runoff, and the last column shows measured runoff divided by precipitation (runoff ratio). 
Table 6. Water balance summaries for 30 basins. These are based on HRU size class 4 for each basin.

\begin{tabular}{|c|c|c|c|c|c|c|}
\hline Gage ID & $\begin{array}{l}\text { Precipitation } \\
(\mathbf{m m})\end{array}$ & $\begin{array}{l}\text { Evapotranspiration } \\
\text { (mm) }\end{array}$ & $\begin{array}{l}\text { Simulated Runoff } \\
(\mathbf{m m})\end{array}$ & $\begin{array}{l}\text { Measured Runoff } \\
(\mathbf{m m})\end{array}$ & Percent Bias & Runoff Ratio \\
\hline 6043500 & $1,276.4$ & 507.6 & 769.6 & 364.3 & $111.2 \%$ & 0.29 \\
\hline 6280300 & 860.9 & 428.0 & 434.4 & 467.1 & $-7.0 \%$ & 0.54 \\
\hline 8324000 & 409.2 & 410.3 & 1.8 & 59.3 & $-97.0 \%$ & 0.14 \\
\hline 9447800 & 440.8 & 424.0 & 19.3 & 13.0 & $48.9 \%$ & 0.03 \\
\hline 9494000 & 746.3 & 617.4 & 130.9 & 103.8 & $26.2 \%$ & 0.14 \\
\hline 9497800 & 532.1 & 485.4 & 49.4 & 52.6 & $-6.2 \%$ & 0.10 \\
\hline 10308200 & $1,104.2$ & 414.6 & 690.6 & 452.0 & $52.8 \%$ & 0.41 \\
\hline 11266500 & $1,278.0$ & 371.0 & 907.0 & 749.1 & $21.1 \%$ & 0.59 \\
\hline 11473900 & $1,191.4$ & 364.1 & 829.8 & 716.9 & $15.8 \%$ & 0.60 \\
\hline 11482500 & $2,682.5$ & 587.8 & $2,093.8$ & $1,218.8$ & $71.8 \%$ & 0.45 \\
\hline 11522500 & $1,776.1$ & 559.8 & $1,215.3$ & 843.5 & $44.1 \%$ & 0.47 \\
\hline 11528700 & $1,836.5$ & 457.6 & $1,380.1$ & 613.3 & $125.0 \%$ & 0.33 \\
\hline 11532500 & 3,379.6 & 716.5 & $2,660.0$ & $2,131.5$ & $24.8 \%$ & 0.63 \\
\hline 12035000 & $2,337.0$ & 564.7 & $1,768.0$ & $2,624.0$ & $-32.6 \%$ & 1.12 \\
\hline 12040500 & $5,918.6$ & 727.0 & $3,697.7$ & $3,804.6$ & $-2.8 \%$ & 0.64 \\
\hline 12189500 & $1,768.3$ & 510.3 & $1,254.4$ & $2,349.7$ & $-46.6 \%$ & 1.33 \\
\hline 12358500 & $1,198.5$ & 477.3 & 720.9 & 916.8 & $-21.4 \%$ & 0.76 \\
\hline 12411000 & $1,076.9$ & 477.3 & 600.9 & 738.4 & $-18.6 \%$ & 0.69 \\
\hline 12413000 & $1,345.9$ & 459.1 & 887.7 & 762.6 & $16.4 \%$ & 0.57 \\
\hline 12414500 & $1,815.6$ & 560.4 & $1,255.2$ & 794.8 & $57.9 \%$ & 0.44 \\
\hline 12451000 & 976.7 & 294.5 & 682.2 & $1,628.5$ & $-58.1 \%$ & 1.67 \\
\hline 13010065 & $1,169.7$ & 453.4 & 717.5 & 703.0 & $2.1 \%$ & 0.60 \\
\hline 13011900 & 626.1 & 414.1 & 214.4 & 575.1 & $-62.7 \%$ & 0.92 \\
\hline
\end{tabular}




\begin{tabular}{|c|c|c|c|c|c|c|}
\hline Gage ID & $\begin{array}{l}\text { Precipitation } \\
(\mathbf{m m})\end{array}$ & $\begin{array}{l}\text { Evapotranspiration } \\
(\mathbf{m m})\end{array}$ & $\begin{array}{l}\text { Simulated Runoff } \\
\text { (mm) }\end{array}$ & $\begin{array}{l}\text { Measured Runoff } \\
(\mathbf{m m})\end{array}$ & Percent Bias & Runoff Ratio \\
\hline 13023000 & 1,076.6 & 462.0 & 616.0 & 498.9 & $23.5 \%$ & 0.46 \\
\hline 13161500 & 287.5 & 269.8 & 20.8 & 89.2 & $-76.7 \%$ & 0.31 \\
\hline 13185000 & 834.0 & 238.7 & 595.1 & 501.5 & $18.7 \%$ & 0.60 \\
\hline 13235000 & $1,234.5$ & 439.6 & 794.7 & 646.6 & $22.9 \%$ & 0.52 \\
\hline 14301000 & $1,510.4$ & 489.2 & $1,022.5$ & $1,401.8$ & $-27.1 \%$ & 0.93 \\
\hline 14306500 & $1,667.7$ & 517.8 & $1,151.4$ & $1,502.0$ & $-23.3 \%$ & 0.90 \\
\hline 14400000 & $3,587.9$ & 782.0 & $2,802.4$ & 2,988.6 & $-6.2 \%$ & 0.83 \\
\hline
\end{tabular}


Table 6 contains several basins that have problematic water balance numbers. For example, basins 12035000 (Satsop River near Satsop, WA), 12189500 (Sauk River near Sauk, WA), and 12451000 (Stehekin River at Stehekin, WA) all show a runoff ratio that is greater than 1 . That is, the mean annual depth of measured flow over the study period was greater than the mean annual precipitation inputs for the study period. In these basins, the climate grid is clearly underestimating total precipitation, and no amount of calibration would lead to a good performance. The underestimation may stem from under-catch in the weather stations used to derive the climate dataset; Legates and Deliberty (1993) estimate precipitation under-catch due to wind at more than $18 \mathrm{~mm}$ per winter month in the coastal northwest. Also, fog drip, or occult precipitation, has been estimated at $30 \%$ of total precipitation in a Douglas Fir forest in the Oregon cascades (Harr, 1982), and could be important in these Washington basins as well. Regardless of the cause of the under-estimation, it might be better to drop these basins from subsequent analyses due to a poor fit between climate inputs and observed flow, and other basins with high runoff ratios (the last column of Table 6) may also be suspicious.

Table 6 also shows that many models have large biases (also apparent in Figure 6). Basins with such poor water balances may not respond well to calibration.

\subsection{Monthly hydrographs for representative basins}

Hydrographs are another key tool used in hydrologic model interpretation. To better understand the behavior of the uncalibrated models, hydrographs were prepared for 6 basins (Figures 7 through 12). These basins, representing a range of geographic areas, have large percent bias values (both positive and negative). One basin with a very small 
percent bias was also included (12040500, Figure 11). Locations of the selected basins are shown in Figure 7. In this map, the basins with hydrographs are labeled with their percent bias over the period 10/1/1987 to $9 / 30 / 2010$.

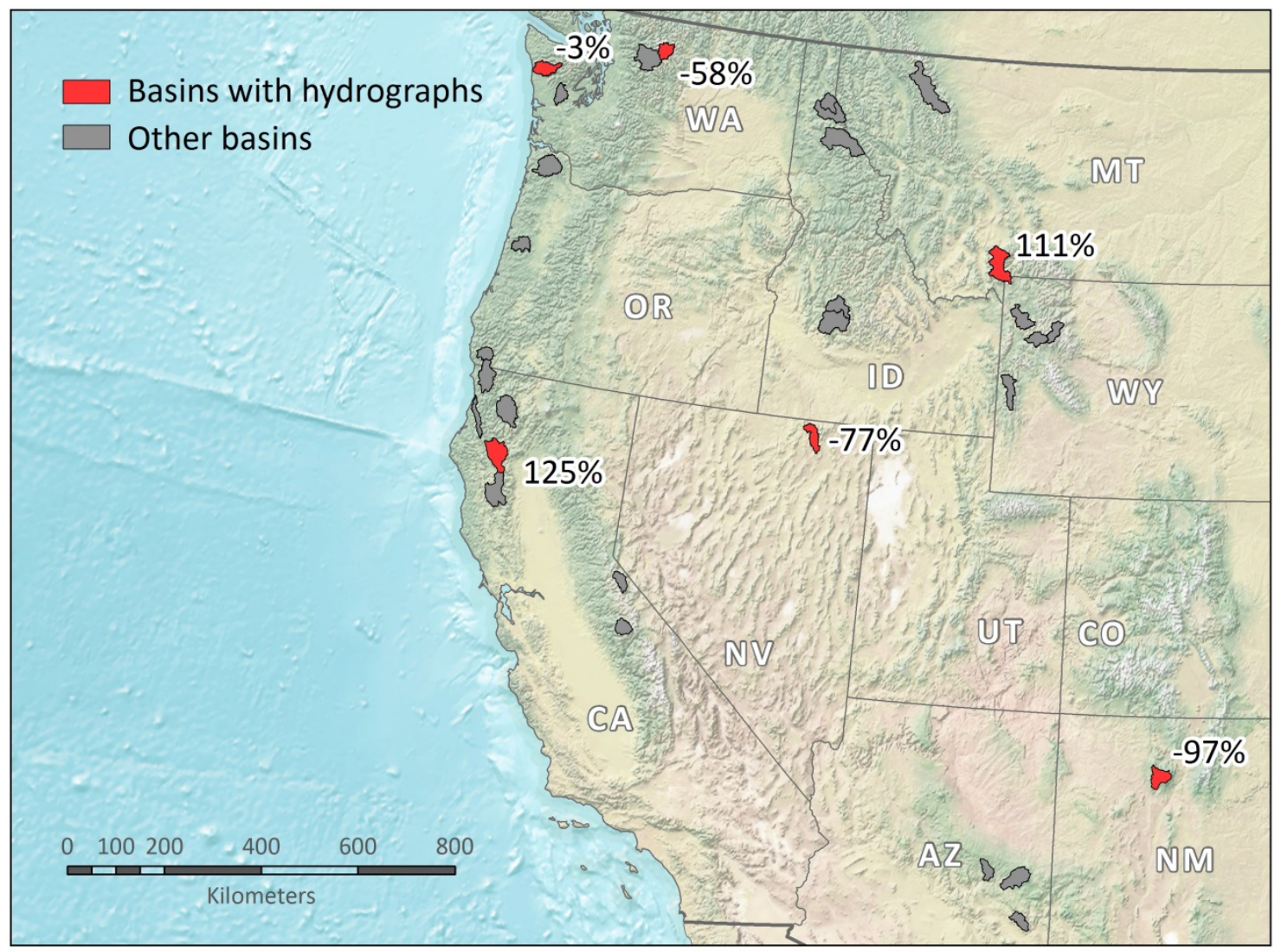

Figure 7. Basins with hydrographs shown below (Figures 8 through 13). Basins with hydrographs are red, and are labeled with their percent bias over the modeled period.

Figures 8 through 13 portray simulated and measured monthly streamflow for each basin over the 20 year period from October 1988 to September 2007. 


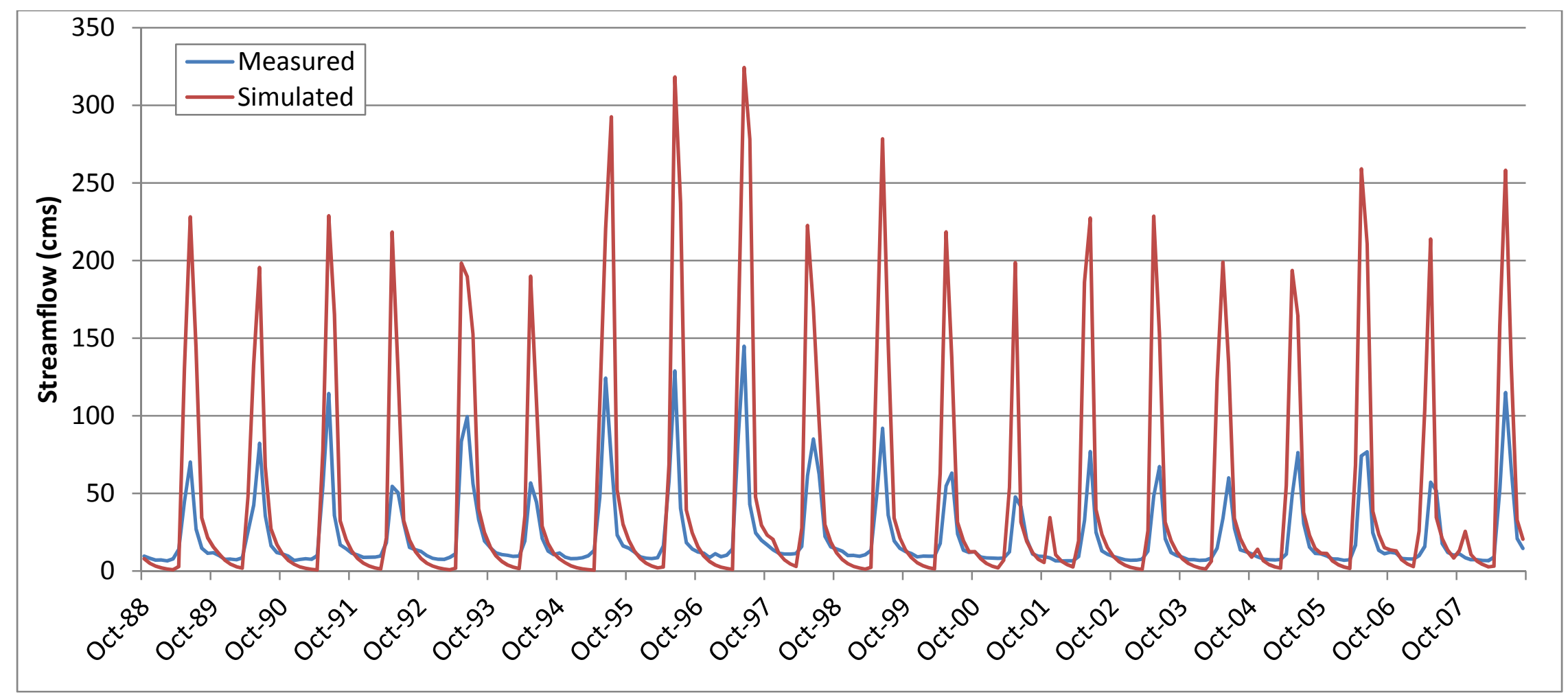

Figure 8. Monthly hydrograph for basin 06043500 (Gallatin River near Gallatin Gateway, MT, median elevation 2,409 m) for Oct. 1988 to Sept. 2007.

This basin shows consistent, strong over-prediction in spring and consistent under-prediction in winter, but the timing is better than in some of the following basins. Goodness of fit could be improved in this basin by using parameter values that increase ET and slow water movement through the system. 


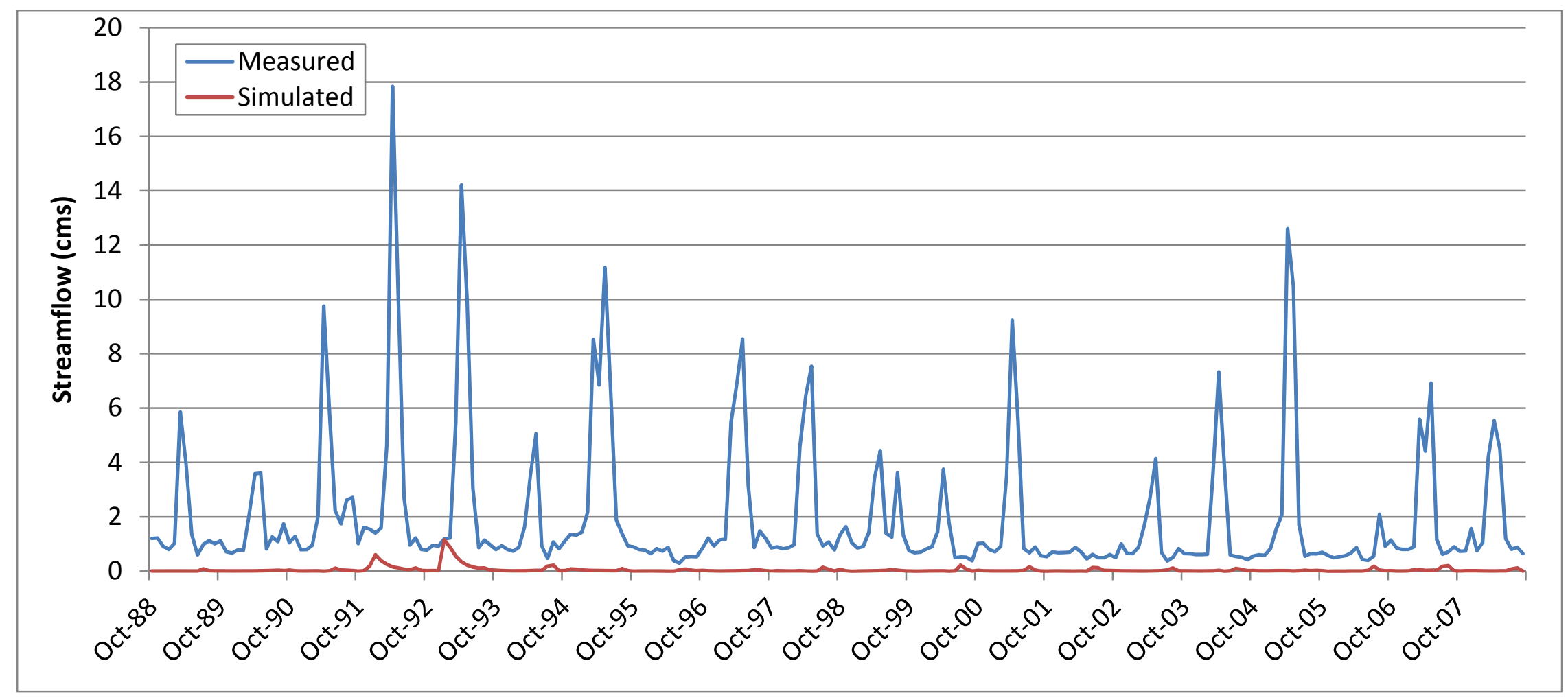

Figure 9. Monthly hydrograph for basin 08324000 (Jemez River near Jemez, NM, median elevation 2613 m) for Oct. 1988 to Sept. 2007.

In this southwestern basin, precipitation inputs are reasonable (see Table 6), but are almost all escaping via ET, and runoff is drastically under-predicted as a result. This basin's performance could be improved by calibrating parameters to decrease ET.

Timing could also be improved, though it is difficult to see timing patterns with simulated flow values so low. The high ET could also be caused by overly high SRAD inputs from the climate grid. If this is the case, calibration may not be very effective. 


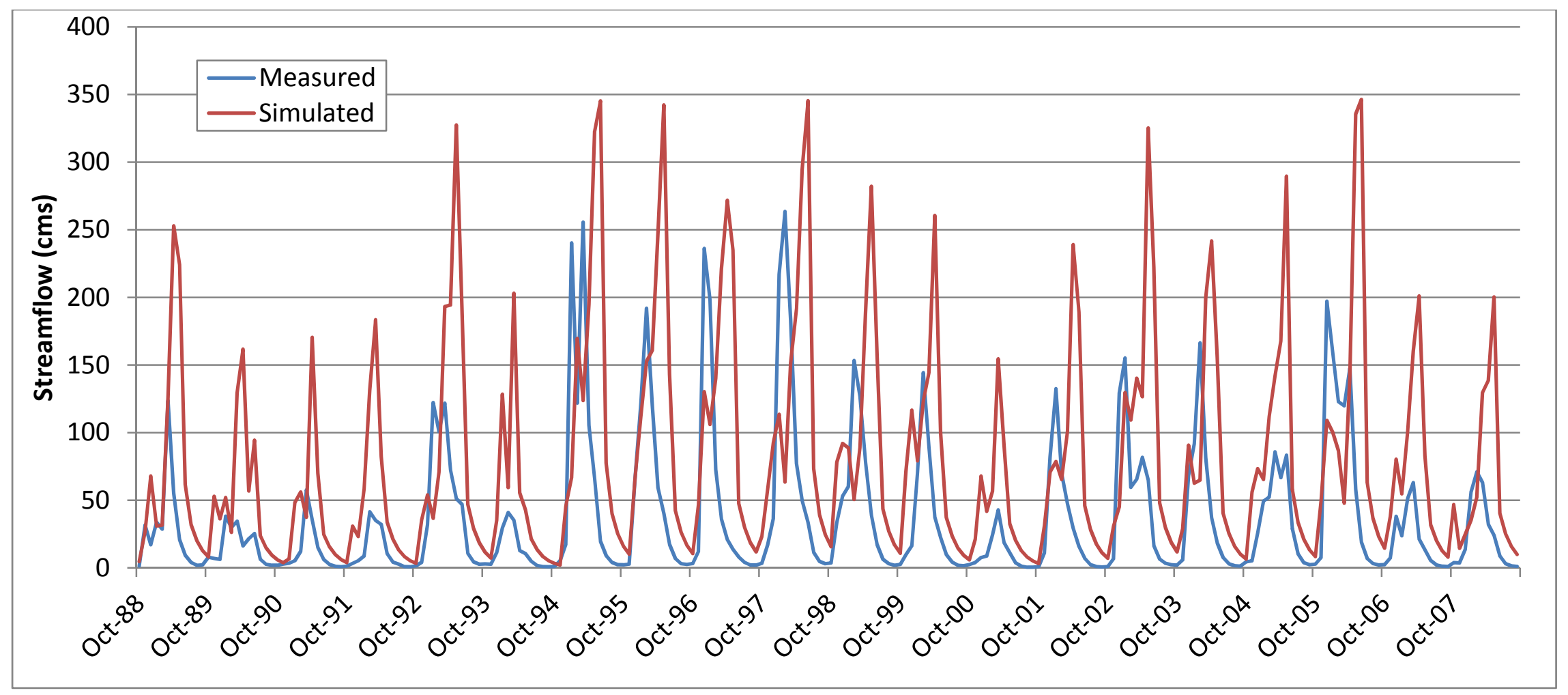

Figure 10. Monthly hydrograph for basin 11528700 (South Fork Trinity River below Hyampom, CA) for Oct. 1988 to Sept. 2007.

This California basin shows high over-prediction as well as problems with timing. In many years, especially the period in the late 1990s, measured runoff peaks in late winter/early spring, whereas simulated runoff peaks in late spring/summer. This suggests that too much precipitation is being held in snow pack in the model. This model could likely be improved by adjusting parameters that affect snow accumulation and snowpack maintenance, and possibly by increasing ET, especially in winter. 


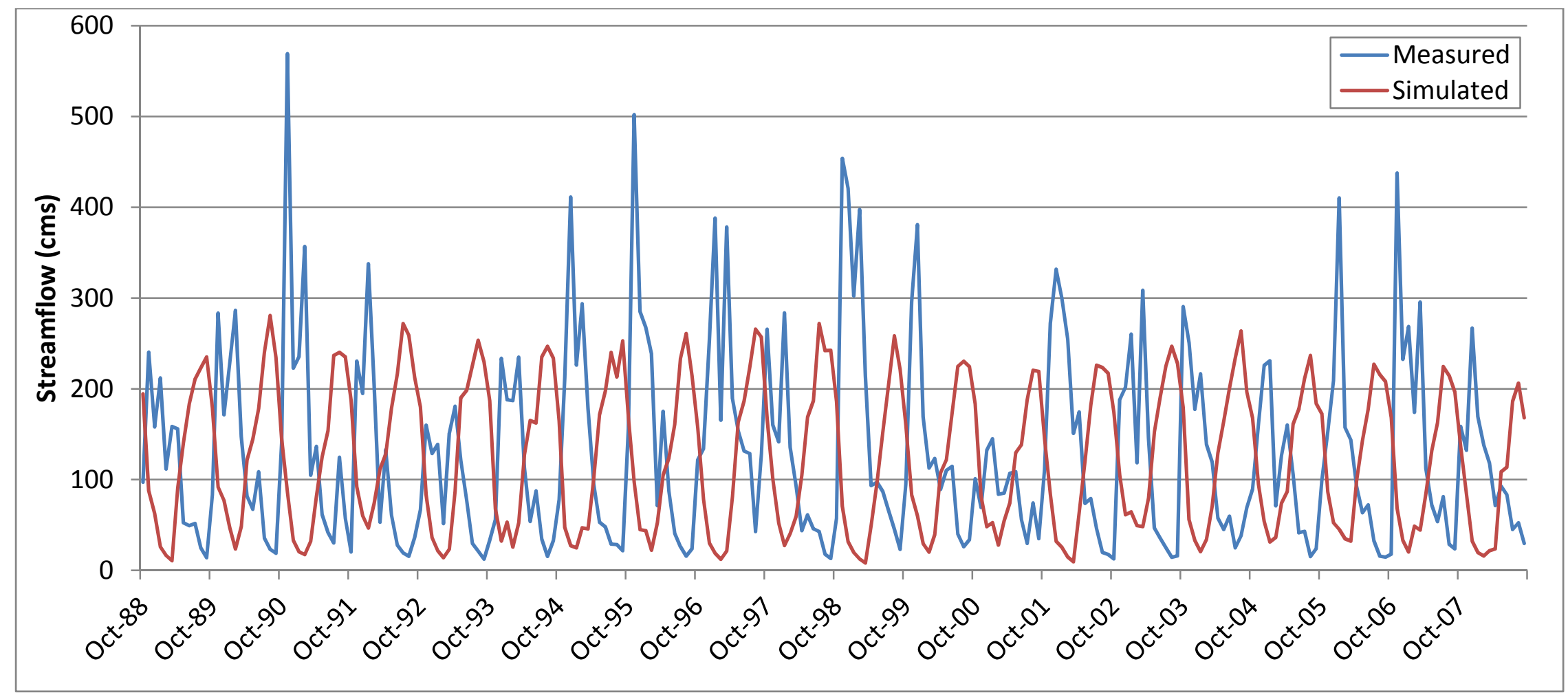

Figure 11. Monthly hydrograph for basin 12040500 (Queets River near Clearwater, WA, median elevation 359 m) for Oct. 1988 to Sept. 2007.

This Washington Basins has very low percent bias, but severe problems with runoff timing. Measured flow peaks in winter, when most precipitation comes to this region, whereas simulated flow peaks in the dry season, indicating that most precipitation is being incorrectly stored in the models snowpack until the warmer months. This could be adjusted with parameters that affect a precipitation phase and snowpack development and evolution. 


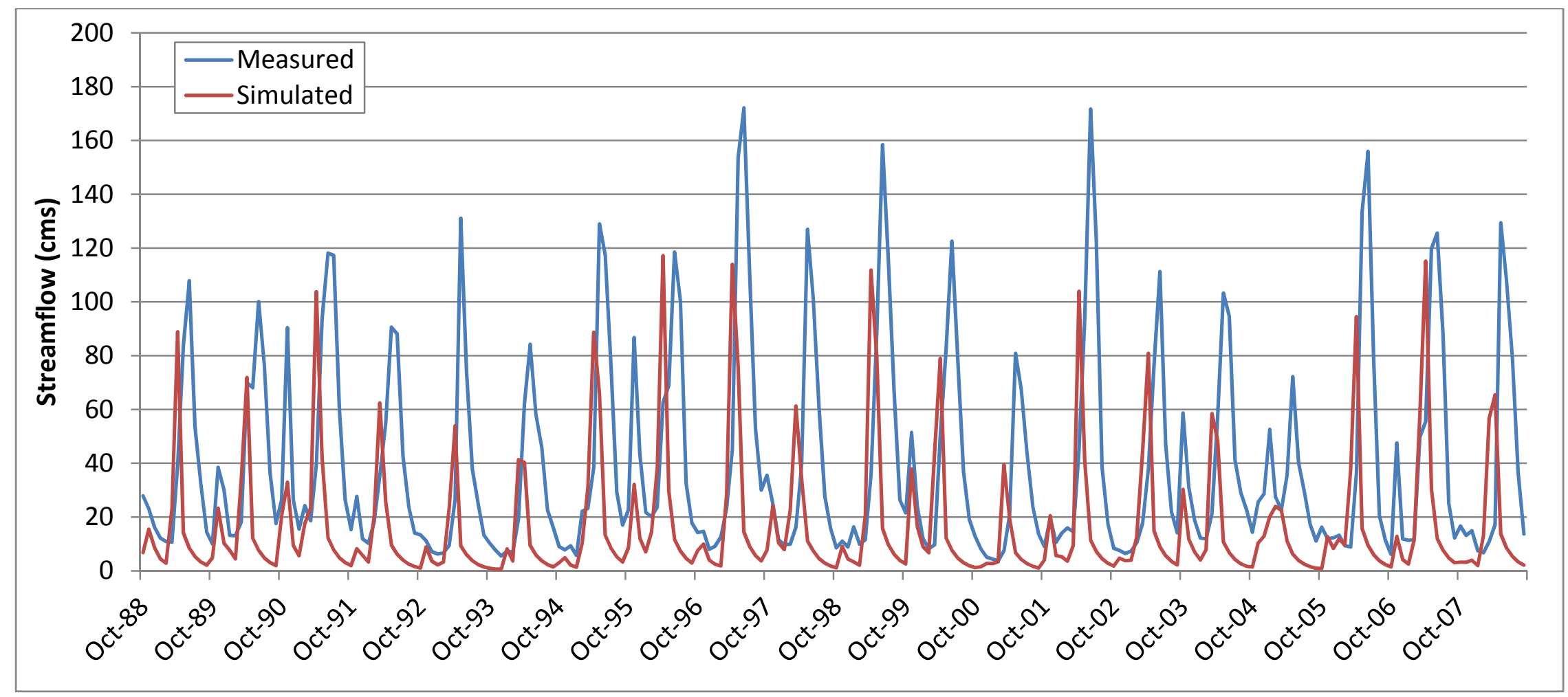

Figure 12. Monthly hydrograph for basin 12451000 (Stehekin River at Stehekin, WA, median elevation 1,588 m) for Oct. 1988 to Sept. 2007.

This Washington basin shows under-prediction and timing problems. Simulated flows peak too early in the year, suggesting that snow is not accumulating properly. Timing could be improved by manipulating parameters related to snow accumulation.

However, under-prediction cannot be entirely fixed without directly manipulating the precipitation inputs. In this basin, measured 
flow/grid precipitation is 1.67 (see Table 6). Climate grid precipitation values are thus too low here. Interbasin groundwater flow could be contributing to the measured flows, but is unlikely to account for much of the discrepancy.

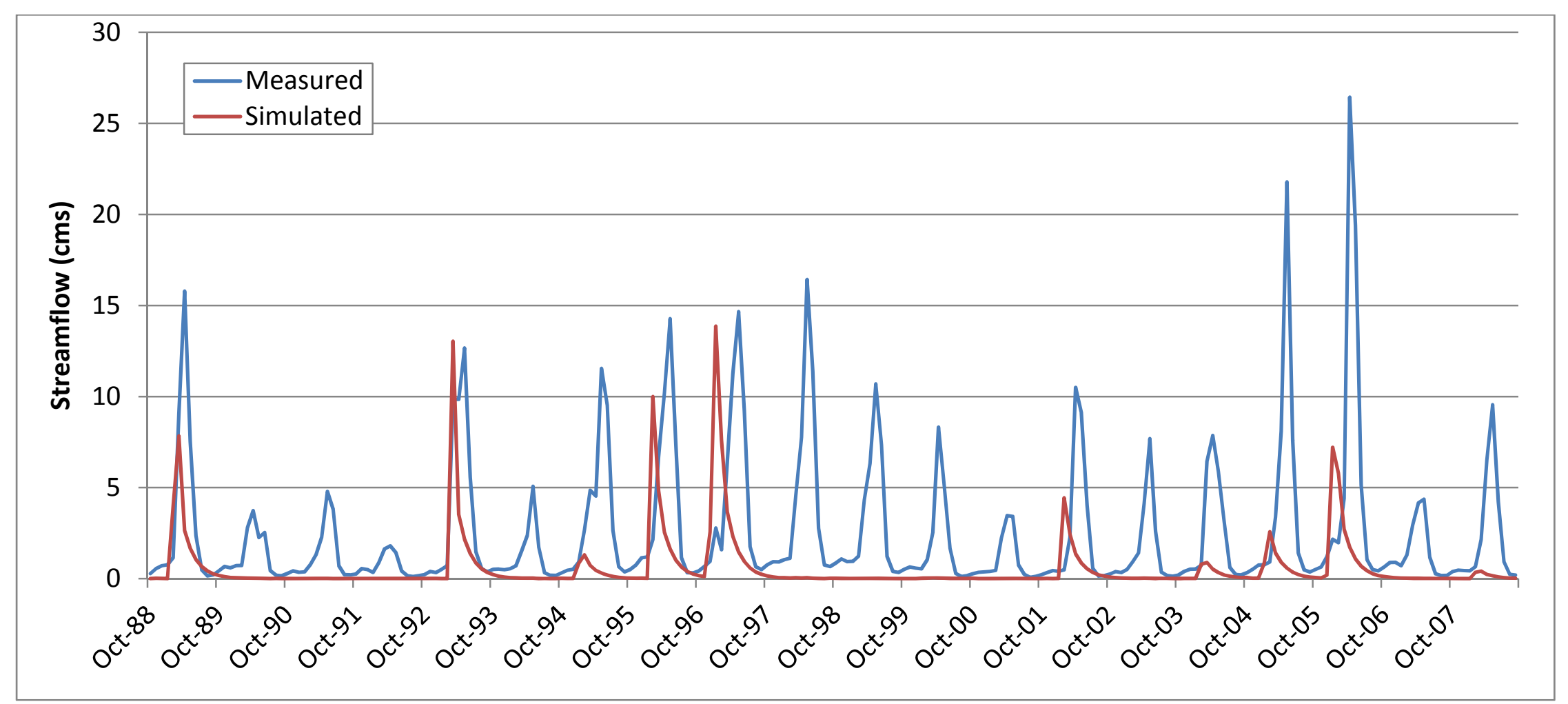

Figure 13. Monthly hydrograph for basin 13161500 (Bruneau River at Rowland, NV, median elevation 2,010 m) for Oct. 1988 to Sept. 2007.

As with the other southwestern basin graphed above (Figure 9), precipitation inputs are reasonable (see Table 6), but are almost

$\infty$ all escaping via ET, and runoff is drastically under-predicted as a result. Thus, this basin's performance could be improved by 
calibrating parameters to decrease ET. Timing is also poor, with measured flows peaking months sooner than measured flows. Manipulation of parameters that affect snow pack development and melt and flow rates through soils could improve timing.

Taken together, these six hydrographs show that the models are performing poorly for a variety of reasons, including excessive ET, poor timing related to both too much and not enough snow, and overestimation. They suggest that automatic calibration should include parameters that influence snow pack formation and melt, ET, and rate of groundwater movement. Many of these problems could be resolved by such calibration, but some may not be adequately responsive to it, especially in those basins where precipitation inputs are too low, which were described above. This will inform extension of this study, but for the current investigation, the assumption is that score variation among the different HRU size classes is informative regardless of model performance, and discussion of this variation, both within and between basins, continues below.

\subsection{Geographic patterns in average model performance and range of model performances}

The boxplots from section 3.1 (Figures 3 through 6) demonstrate that no single HRU size class performs better across basins, but they give no indication as to possible geographic variation in goodness of fit. Figures 14 through 16 display that the spatial patterns in performance vary for IoA, NSE, and PB. The values shown for each basin in these maps were created by averaging performance across all 6 size classes. These averaged values, of course, cannot answer the question of how HRU size affects performance, but the patterns in performance are interesting, especially when contrasted with patterns in range. For $r$ (Figure 14), basins with poorer performance (light yellow) 
seem to be more common in the west and especially in Washington. The negative $r$ values in these Washington basins likely relate to the problems in flow timing illustrated in Figure 11. The pattern for NSE (Figure 15) is quite different, with western and northwestern basins doing relatively well (darker green). A similar pattern appears for PB (Figure 16); basins in Washington and Oregon are closer to the ideal value of 0 than are many basins in other regions, and basins that have strong overestimation (e.g., the basin in southern Montana) also have poor NSE values. Similarities in the patterns for these two metrics are not surprising, as finding the ratio of simulated to measured flow (PB) is part of the calculation of NSE (Nash and Sutcliffe, 1970).

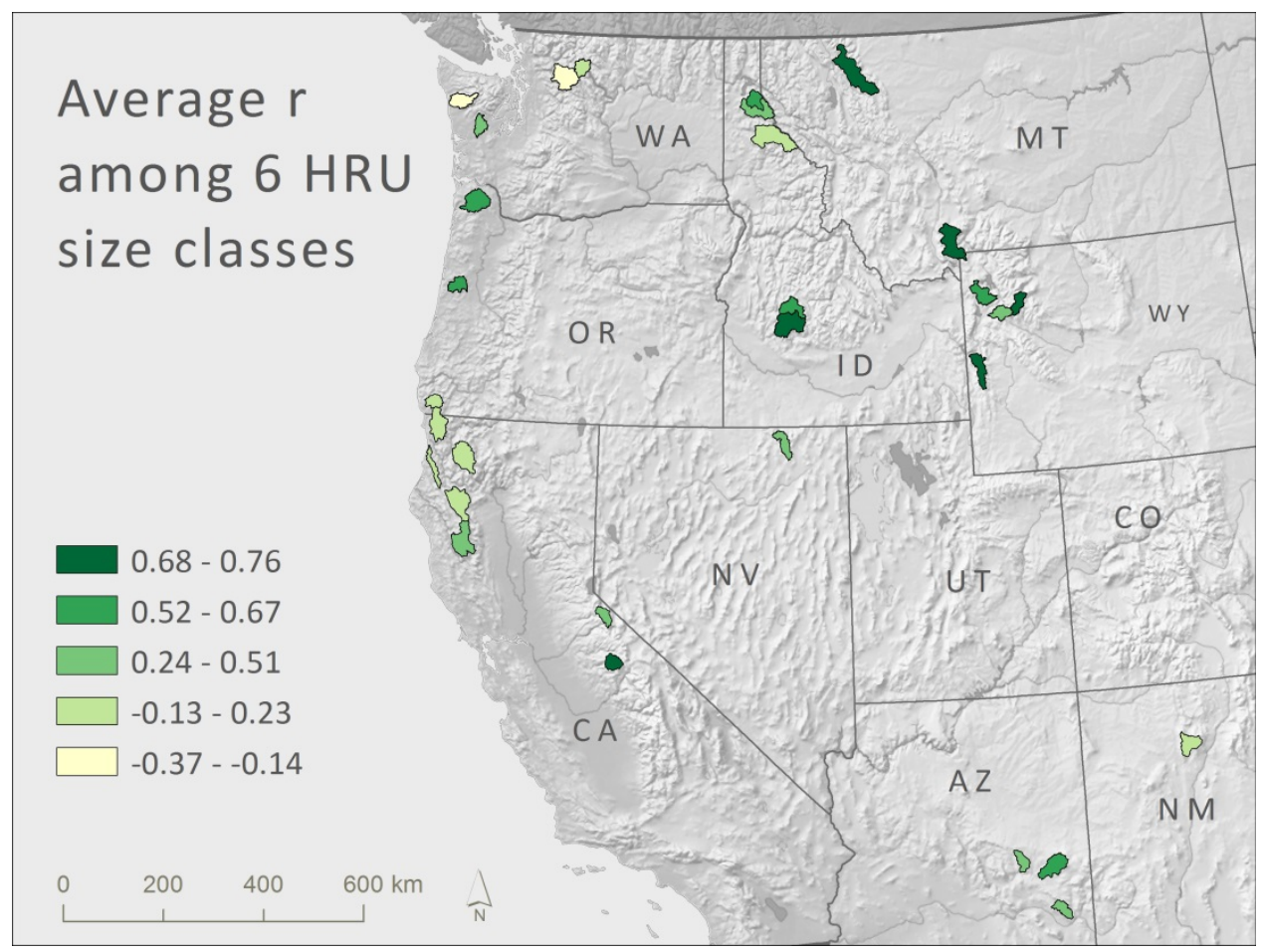

Figure 14. Average Correlation Coefficient (r) among 6 HRU size classes by basin for the period 10/1/1987-9/30/2010. 


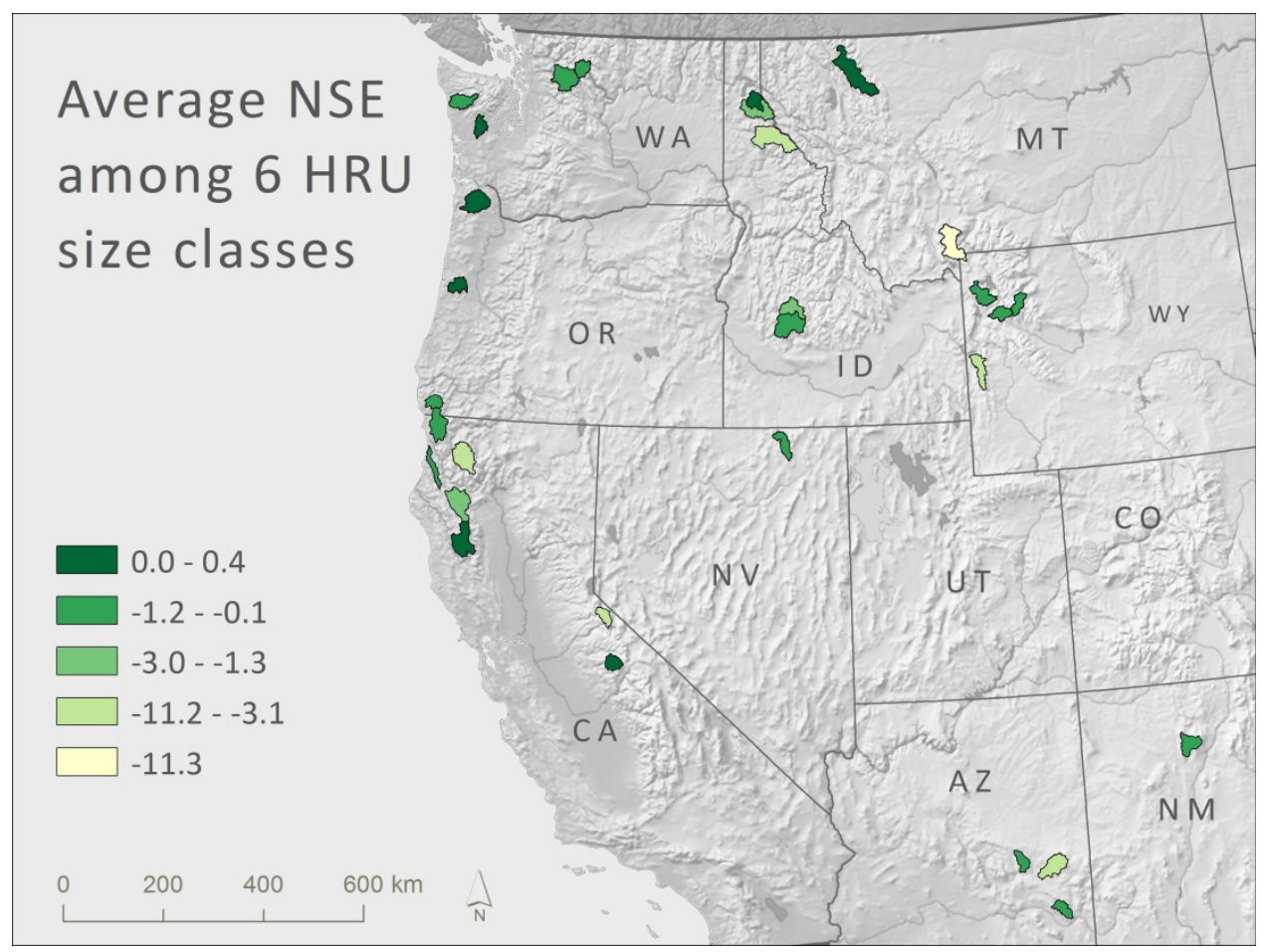

Figure 15. Average Nashe-Sutcliffe Efficiency (NSE) among 6 HRU size classes by basin for the period 10/1/1987-9/30/2010.

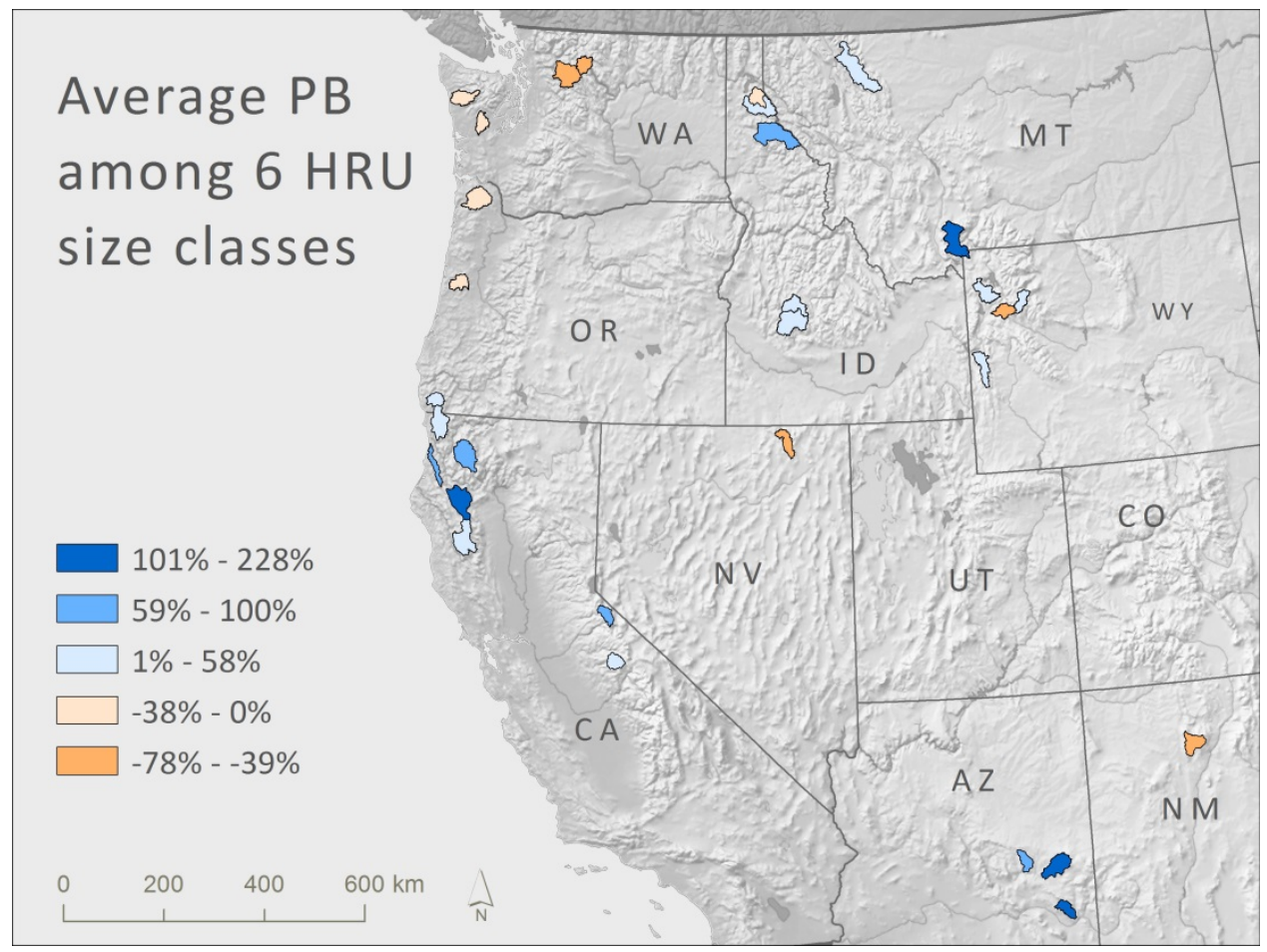

Figure 16. Average Percent Bias among 6 HRU size classes by basin for the period 10/1/19879/30/2010. 
Figures 14 through 16 illustrate spatial variability in model performance, but not in the effects of HRU size on model performance. This effect is best quantified by the range of goodness-of-fit scores across all 6 HRU size classes for each individual basin, which provides a rough metric of model sensitivity to HRU size. In the rest of this document, the goodness-of-fit range will be treated as synonymous to "HRU size sensitivity." It should be noted, however, that the same range value may reflect different HRU size sensitivity, because goodness of fit scores are not truly linear. For example, the NSE value pairs of $[-1,-3]$ and $[-100,-102]$ have the same range, but the second pair indicates less sensitivity than the first pair. For this reason, range values in IoA and $r$ are probably more reliable metrics for HRU size sensitivity than range values in NSE and PB, and so the latter should be interpreted with caution.

Figures 17 and 18 show the range of two goodness-of-fit scores, IoA and NSE. The color of each basin indicates the range in its 6 performance metrics. Although the spatial patterns were different for $r$ and NSE on average (see Figures 14 and 15), Figures 17 and 18 seem to have a consistent spatial pattern. In both, the western regions, especially the Pacific Northwest, are less affected by HRU size (light yellow represents a smaller range). Further east, the ranges are higher, indicating a heightened sensitivity to HRU size (darker green). This variation suggests that there may be a geographic pattern in basin HRU size sensitivity, regardless of which metric is used. 


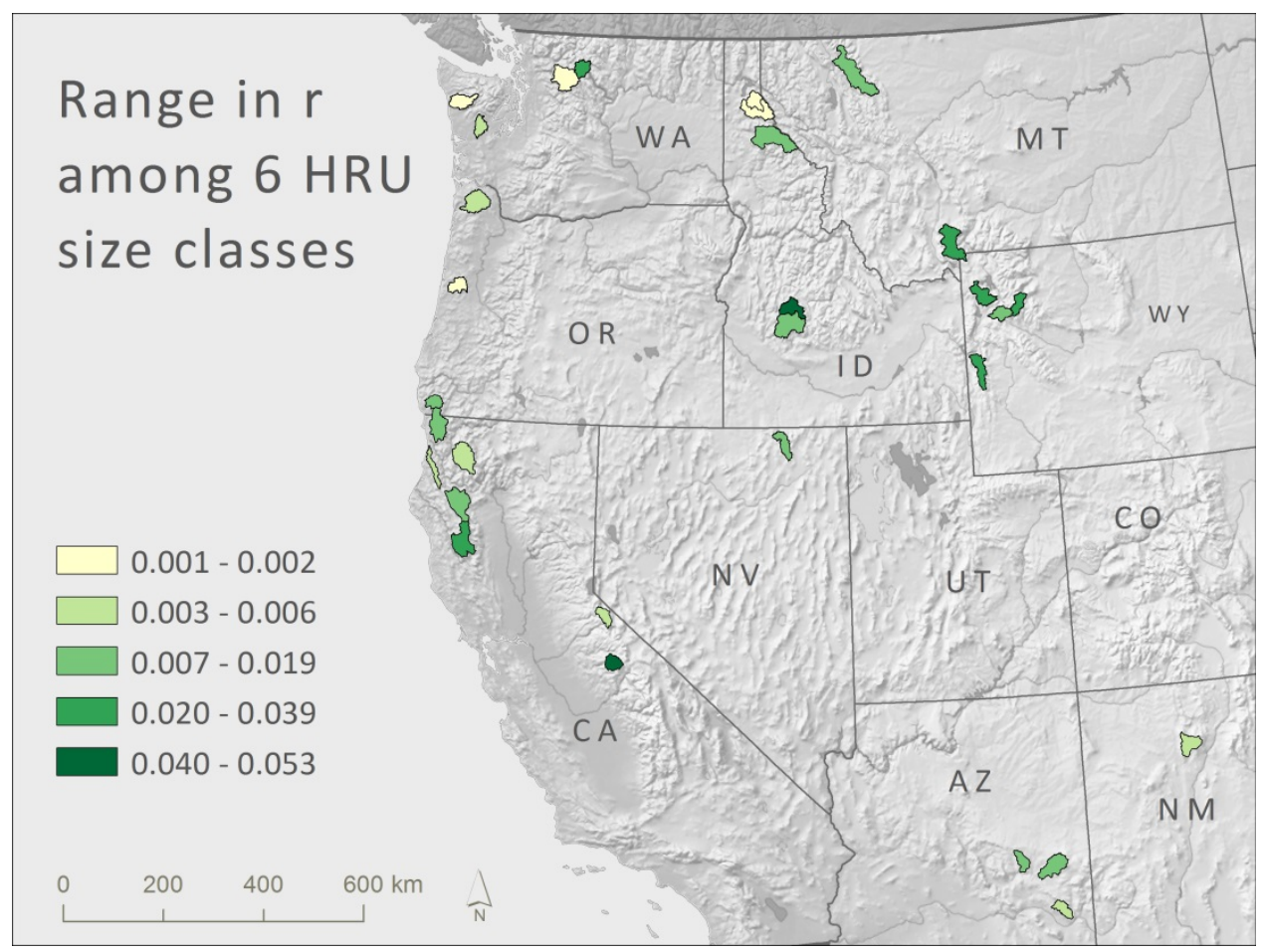

Figure 17. Range in Correlation Coefficient ( $r$ ) among 6 HRU size classes by basin for the period 10/1/1987-9/30/2010.

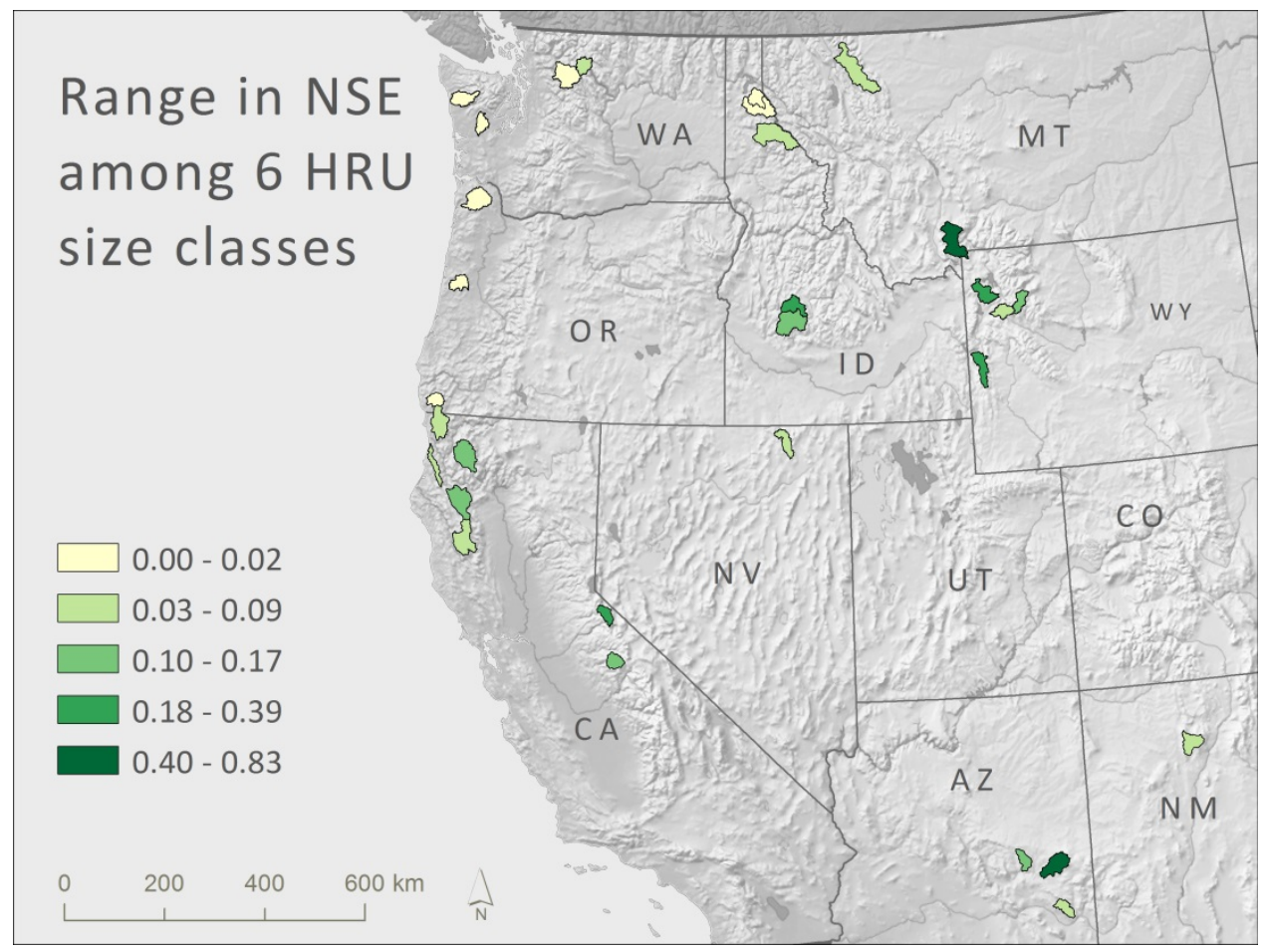

Figure 18. Range in Nashe-Sutcliffe Efficiency (NSE) among 6 HRU size classes by basin for the period 10/1/1987-9/30/2010. 
The statistical significance of these patterns was tested using Moran's I; (see Table 7 for results).

Table 7. Results of Moran's $I$ analysis for goodness of fit means and ranges. Correlations that are significant at the pseudo $\boldsymbol{p}$-value $=\mathbf{0 . 0 1}$ level are highlighted in green, and those that are significant at the pseudo $p$-value $=0.05$ level are shown in yellow .

\begin{tabular}{|l|c|c|}
\hline \hline Variable & Moran's $\boldsymbol{I}$ & Pseudo $\boldsymbol{p}$-value \\
\hline \hline Mean $r$ & 0.2433 & 0.016 \\
\hline Mean NSE & -0.0655 & 0.401 \\
\hline Mean IOA & 0.1104 & 0.078 \\
\hline Mean PB & 0.1273 & 0.057 \\
\hline Range in $r$ & 0.1819 & 0.027 \\
\hline Range in NSE & 0.1199 & 0.043 \\
\hline Range in IoA & 0.2882 & 0.004 \\
\hline Range in PB & -0.0311 & 0.440 \\
\hline \hline
\end{tabular}

The clearest result of this analysis is that goodness of fit range scores do seem to exhibit more clustering than average goodness of fit scores. This confirms that the patterns suggested by Figures 17 and 18 are probably significant. Two of the range metrics are clustered with $95 \%$ confidence and one of them has $99 \%$ confidence. Among average scores, only one (mean $r$ ) shows significant clustering. It should be noted, however, that the clustering is not very strong, and the Moran's I scores are not very high. Positive scores indicate that the data are more clustered than dispersed, but the values all have an absolute value of less than 0.3 . Generally, a Moran's I score with an absolute value of 0.3 or more is indicative of relatively strong clustering or dispersal (O’Sullivan and Unwin, 2010). This suggests that the patterns shown by Figures 17 and 18 may not be especially important. Further, Moran's $I$ is a global metric, and does not 
indicate where the clustering actually occurs. It may be in the northwest, as our eyes suggest, but it may also be elsewhere.

\subsection{Correlations between basin characteristics and range in goodness of fit scores by} basin

The geographic pattern in HRU size sensitivity suggested by Figures 17 and 18 could be driven by numerous variables. Elevation, precipitation, or the type of precipitation system (frontal vs. convective) could be contributing to it, and it could also be influenced by land cover type, temperature, and other factors. All of these factors, when mapped, seem to vary along a similar gradient. In order to obtain more insight into these relationships, some statistical comparisons were performed. This analysis is only intended to show interesting correlations, not causation; there are too many variables and too few samples for the latter. The ranges in the 4 goodness-of-fit metrics were correlated with a set of basin characteristic variables as described in the Data and Methods section (see Appendix A for the list of basin variables). Results from these correlations are shown in Table 8. Only those variables that had at least one correlation significant at the $p=0.01$ (99\% confidence) level and a correlation number with an absolute value greater than 0.5 are shown. Correlations with absolute values greater than $0.5,0.6$, and 0.7 are highlighted in light, medium, and dark blue, respectively.

Several of the variables with the strongest correlations to the range scores are mean annual precipitation and the related variables of average runoff depth, average monthly maximum days of precipitation, and average April and May precipitation. These numbers are all negatively correlated to the range in model performance. That is, the correlations imply that models of basins with high levels of rainfall are less likely to be sensitive to 
HRU size. It should be stressed, however, that precipitation is strongly correlated to many other basin variables, including LULC, longitude, and elevation. The observed correlation does not indicate as to which of these interrelated variables are responsible for the decrease in HRU size sensitivity associated with higher precipitation.

One possible driver of lower HRU size sensitivity in wetter areas may be the type of precipitation delivery rather than the total volume. The wettest basins are in the Pacific Northwest, and most of that rain is delivered by large synoptic-scale winter frontal systems that are consistent over large areas. In dryer inland areas, convective systems are more important, and these can have much more localized effects (Abatzoglou, 2011). This smaller-scale variation in climate inputs in dryer areas could explain the fact that dryer basins are more sensitive to HRU size, as smaller subdivisions might be need to capture variability in climate inputs.

These patterns in HRU size sensitivity could also be driven by elevation. Table 8 shows that elevation is strongly positively correlated to HRU size range. This could be because, in snow-dominated areas, it is key to use HRU subdivision to distinguish between source and non-source areas. In high elevation "source areas," snow pack can accumulate all winter long and contribute to streamflow throughout the spring and summer, whereas a basin's lower elevation areas might provide no significant runoff in spring and summer. It may be the importance of capturing this distinction that drives sensitivity in these high elevation basins. For the study basins, average precipitation is strongly negatively correlated with elevation, because the westernmost basins are wetter and lower than the interior basins. Thus, the source/non-source driver could also explain 
Table 8. Spearman's rank correlation coefficients between basin variables and ranges in model performance scores. Model performance range scores are for the total modeled period (10/1/1985-9/30/2010). Only those variables that had at least one correlation with an absolute value of greater than 0.5 and a significance at the alpha $=0.01$ level are shown in this table. Correlations that are significant at alpha $=0.01$ level are followed by two stars. Alpha levels of 0.05 followed by one star. Correlations with an absolute value of greater than $0.5,0.6$, and 0.7 are highlighted in light, medium, and dark blue, respectively.

\begin{tabular}{|c|c|c|c|c|c|}
\hline Variable & Brief variable description & Range in $r$ & $\begin{array}{c}\text { Range in } \\
\text { NSE }\end{array}$ & Range in IoA & Range in PB \\
\hline LONG_CENT & Longitude of basin centroid & $.405^{\star}$ & $.490^{\star \star}$ & $.438^{\star}$ & $.563^{\star \star}$ \\
\hline PPTAVG_BASIN & Mean annual precip & $-.395^{\star}$ & $-.523^{\star \star}$ & $-.477^{\star \star}$ & $-.692^{\star \star}$ \\
\hline T_MAXSTD_BASIN & Standard deviation of max. monthly air temp. (degrees C) & $.366^{\star}$ & $.540^{\star \star}$ & 0.339 & $.456^{\star}$ \\
\hline T_MIN_BASIN & Mean of min. monthly air temp. (degrees C) & $-.498^{\star \star}$ & $-.599^{\star \star}$ & $-.430^{\star}$ & -0.309 \\
\hline $\mathrm{RH} B \mathrm{BASIN}$ & Mean relative humidity (percent) & $-.504^{\star *}$ & $-.631^{\star *}$ & $-.572^{\star \star}$ & $-.668^{\star *}$ \\
\hline FST32F_BASIN & Mean of mean day of the year of first freeze & $-.391^{\star}$ & $-.529^{\star \star}$ & -0.341 & -0.292 \\
\hline LST32F_BASIN & Mean of mean day of the year of last freeze & $.471^{\star \star}$ & $.613^{\star \star}$ & $.443^{\star}$ & 0.35 \\
\hline WD BASIN & Mean of annual number of days (days) of measurable precip. & $-.452^{\star}$ & $-.510^{\star *}$ & $-.517^{\star \star}$ & $-.709 * \star$ \\
\hline WDMAX_BASIN & Mean of monthly max. number of days of precip. & $-.446^{\star}$ & $-.570^{\star \star}$ & $-.552^{\star \star}$ & $-.709^{\star \star *}$ \\
\hline SNOW_PCT_PRECIP & Snow percent of total precip. estimate & $.431^{\star}$ & $.571^{\star \star}$ & 0.328 & 0.291 \\
\hline JAN_PPT7100_CM & Mean January precip $(\mathrm{cm})$ & $-.387^{\star}$ & $-.487^{\star \star}$ & $-.444^{*}$ & $-.684^{\star \star}$ \\
\hline FEB_PPT7100_CM & Mean February precip (cm) & -0.354 & $-.444^{\star}$ & $-.383^{\star}$ & $-.653^{\star \star}$ \\
\hline MAR_PPT7100_CM & Mean March precip (cm) & -0.334 & $-.410^{\star}$ & $-.370^{\star}$ & $-.667^{\star \star}$ \\
\hline APR_PPT7100_CM & Mean April precip (cm) & $-.391^{\star}$ & $-.5599^{\star \star}$ & $-.514^{\star \star}$ & $-.741^{\star *}$ \\
\hline MAY_PPT7100_CM & Mean May precip (cm) & -0.35 & $-.495^{\star \star}$ & $-.439^{\star}$ & $-.743^{\star \star}$ \\
\hline JUN_PPT7100_CM & Mean June precip (cm) & $-.380^{\star}$ & $-.444^{*}$ & $-.440^{\star}$ & $-.628^{\star \star}$ \\
\hline SEP_PPT7100_CM & Mean September precip (cm) & $-.430^{\star}$ & $-.509^{\star \star}$ & $-.523^{\star \star}$ & $-.531^{\star \star}$ \\
\hline OCT_PPT7100_CM & Mean October precip (cm) & $-.440^{\star}$ & $-.540^{\star \star}$ & $-.513^{\star \star}$ & $-.689^{\star \star}$ \\
\hline NOV_PPT7100_CM & Mean November precip (cm) & $-.425^{\star}$ & $-.543^{\star \star}$ & $-.504^{\star \star}$ & $-.684^{\star \star}$ \\
\hline DEC_PPT7100_CM & Mean December precip $(\mathrm{cm})$ & $-.383^{\star}$ & $-.514^{\star \star}$ & $-.459^{\star}$ & $-.666^{\star *}$ \\
\hline FEB_TMP7100_DEGC & Mean February air temp. & $-.449^{\star}$ & $-.518^{\star \star}$ & -0.337 & -0.273 \\
\hline
\end{tabular}




\begin{tabular}{|c|c|c|c|c|c|}
\hline Variable & Brief variable description & Range in $r$ & $\begin{array}{c}\text { Range in } \\
\text { NSE }\end{array}$ & Range in loA & Range in PB \\
\hline MAR_TMP7100_DEGC & Mean March air temp. & $-.455^{\star}$ & $-.544^{\star \star}$ & -0.347 & -0.244 \\
\hline APR TMP7100 DEGC & Mean April air temp. & $-.425^{\star}$ & $-.513^{\star \star}$ & -0.31 & -0.186 \\
\hline FRAGUN BASIN & Fragmentation Index of "undeveloped" land & -0.139 & -0.334 & -0.028 & $-.578^{\star \star}$ \\
\hline $\begin{array}{l}\text { HIRES_LENTIC_MEANSI } \\
Z\end{array}$ & Mean size (ha) of Lakes/Ponds & 0.298 & $.500^{\star *}$ & 0.295 & 0.05 \\
\hline HIRES_LENTIC_PCT & Percent of surface area covered by Lakes/ponds & $.416^{*}$ & $.500^{\star *}$ & $.457^{\star}$ & 0.193 \\
\hline BFI_AVE & Base Fow Index (BFI) & 0.307 & $.520^{\star *}$ & 0.256 & 0.212 \\
\hline PERDUN & Percent Dunne overland flow & -0.261 & -0.275 & -0.147 & $-.552^{\star *}$ \\
\hline RUNAVE7100 & Estimated annual runoff, mm/year & $-.435^{\star}$ & $-.573^{\star \star}$ & $-.512^{\star \star}$ & $-.763^{\star *}$ \\
\hline WB5100_JAN_MM & Estimated January runoff, mm/month & $-.439^{*}$ & $-.504^{\star \star}$ & $-.404^{\star}$ & $-.652^{\star \star}$ \\
\hline WB5100_FEB_MM & Estimated February runoff, mm/month & $-.480^{\star *}$ & $-.526^{\star *}$ & $-.424^{\star}$ & $-.588^{\star \star}$ \\
\hline WB5100_MAR_MM & Estimated March runoff, mm/month & $-.496^{\star *}$ & $-.561^{\star \star}$ & $-.458^{*}$ & $-.533^{\star \star}$ \\
\hline WB5100_APR_MM & Estimated April runoff, $\mathrm{mm} / \mathrm{month}$ & $-.500^{\star \star}$ & $-.557^{\star \star}$ & $-.521^{\star \star}$ & $-.614^{\star \star}$ \\
\hline WB5100_MAY_MM & Estimated May runoff, mm/month & $-.454^{\star}$ & $-.523^{\star \star}$ & $-.539 * \star$ & $-.624^{\star \star}$ \\
\hline WB5100_NOV_MM & Estimated November runoff, mm/month & $-.378^{\star}$ & $-.498^{\star \star}$ & $-.453^{\star}$ & $-.699^{\star \star}$ \\
\hline WB5100_DEC_MM & Estimated December runoff, mm/month & $-.398^{\star}$ & $-.493^{\star \star}$ & $-.425^{\star}$ & $-.676^{\star *}$ \\
\hline WB5100_ANN_MM & Estimated annual runoff, mm/year & -0.344 & $-.509^{\star \star}$ & $-.405^{*}$ & $-.731^{\star \star}$ \\
\hline FORESTNLCDO6 & Percent NLCD 'forest" & $-.569^{\star \star}$ & $-.371^{\star}$ & $-.504^{\star \star}$ & $-.409^{\star}$ \\
\hline MIXEDFORNLCDO6 & Percent NLCD Mixed Forest (class 43) & -0.278 & $-.494^{\star \star}$ & -0.348 & $-.685^{\star \star}$ \\
\hline GRASSNLCDO6 & Percent NLCD Herbaceous (grassland) (class 71) & $.517^{\star \star}$ & 0.324 & 0.282 & 0.135 \\
\hline ROADS_KM_SQ KM & Road density, km of roads per sq km & $-.553^{\star *}$ & $-.530^{\star \star}$ & $-.408^{\star}$ & -0.306 \\
\hline HGD & Percentage of soils in hydrologic group D (clayey, low infilitration) & $.485^{\star \star}$ & $.372^{\star}$ & $.508^{\star \star}$ & $.378^{\star}$ \\
\hline BDAVE & Mean value of bulk density (grams per cubic centimeter) & $.594^{\star *}$ & $.645^{\star *}$ & $.652^{\star *}$ & $.512^{\star \star}$ \\
\hline SILTAVE & Mean value of silt content (percentage) & $-.438^{\star}$ & $-.560^{\star *}$ & $-.504^{\star \star}$ & $-.597^{\star \star}$ \\
\hline RFACT & Rainfall and Runoff factor ("R factor" of Universal Soil Loss Equation) & $-.465^{\star \star}$ & $-.525^{\star *}$ & $-.445^{\star}$ & $-.463^{\star \star}$ \\
\hline
\end{tabular}




\begin{tabular}{|c|c|c|c|c|c|}
\hline Variable & Brief variable description & Range in $r$ & $\begin{array}{c}\text { Range in } \\
\text { NSE }\end{array}$ & Range in loA & Range in PB \\
\hline EEEV_MEAN_M BASIN & Mean elevation (meters) & $.574^{\star \star}$ & $.680^{\star x}$ & $.521^{\star \star}$ & $.566^{\star \star}$ \\
\hline EEEV_MAX_M_BASIN & Max. elevation (meters) & $.538^{\star \star}$ & $.733^{\star *}$ & $.514^{\star \star}$ & $.533^{\star \star}$ \\
\hline EEEV_MIN_M BASIN & Min. elevation (meters) & $.538^{\star \star}$ & $.635^{\star \star}$ & $.545^{\star \star}$ & $.522^{\star \star}$ \\
\hline ELEV_MEDIAN M BASIN & Median elevation (meters) & $.577^{\star \star}$ & $.684^{\star \star}$ & $.514^{\star \star}$ & $.558^{\star \star}$ \\
\hline RRMEAN & $\begin{array}{l}\text { Dimensionless elevation - relief ratio, calculated as } \\
\text { (EEV_MEAN - EEV MIN)/(ELE_MAX- EEV_MIN). }\end{array}$ & $.531^{\star \star}$ & $.506^{\star \star}$ & 0.311 & $.591^{\star \star}$ \\
\hline RRMEDIAN & $\begin{array}{l}\text { Dimensionless elevation - relief ratio, calculated as } \\
\text { (EEV_MEDIAN - ELEV MIN)/(ELEV_MAX - ELEV_MIN). }\end{array}$ & $.538^{\star \star}$ & $.538^{\star \star}$ & 0.309 & $.572^{\star \star}$ \\
\hline
\end{tabular}


the correlations between HRU size sensitivity and precipitation, which is so closely related to elevation. All of these interpretations, however, are speculative, as these statistics show correlation only, not causality.

RRMEAN and RRMEDIAN, two measures of terrain roughness, also show positive correlation to score ranges. It seems logical that rougher landscapes should require more subdivision (Wood et al. [1988] came to this conclusion). These metrics co-vary with elevation, however, and so the driver could be the terrain roughness, the source/nonsource issue described above, or some combination of these and other factors.

It is also key to stress that, although there is some variation in goodness-of-fit score ranges, this does not mean that basins with lower precipitation or higher elevation are sensitive to HRU size. They are just slightly more sensitive than the other basins. Figure 19, which shows a boxplot of $r$ scores for the 10 driest basins (as defined by GAGES II averages), separated by HRU size class, illustrates this point. Although drier basins may have higher $r$ ranges on average, there is still almost no variation between the six HRU size classes. The boxplot that shows $r$ for all 30 basins (Figure 3 ) is a bit more consistent across the classes, but negligibly so. 


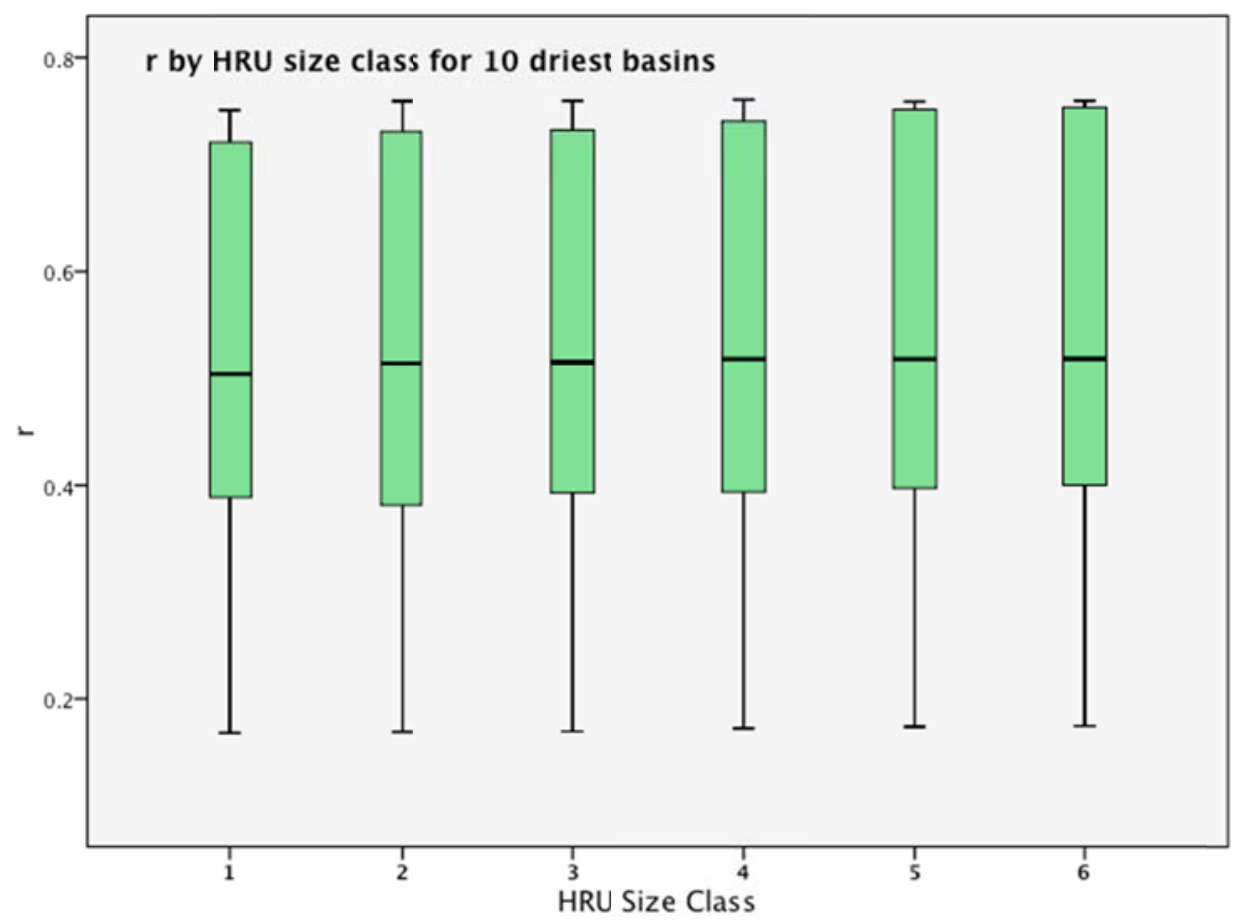

Figure 19. Correlation Coefficient ( $r$ ) for 10 driest basins, divided into 6 HRU size classes, for the period 10/1/1987-9/30/2010.

\subsection{Caveats of this study}

This study has several important limitations and assumptions. It was conducted only with PRMS, and it is not clear if the findings will be directly useful for other semidistributed models in other regions. Also, it considered only mountainous, fairly undisturbed basins; results could be different in lowland, disturbed basins. The study focused only on accuracy of daily streamflow simulation at the mouth of the basin, though many other aspects of the water cycle could have been considered. Some studies have indicated that model subdivision can have only minor effects on streamflow, but that other variables, such as evaporation (Tripathi et al., 2006) or sediment and nutrient loads (Arabi et al., 2006; Jha et al., 2004), can be affected differently. The study could 
also have considered more goodness-of-fit metrics for daily streamflow, and considered monthly and seasonal performance as well, which are likely to result in different performance.

Further, the models were not calibrated due to time limitations and concerns that stochastic calibration could impair model comparability. Thus, the model performance scores were poor. It was assumed that the outputs of these uncalibrated models, which would be unsatisfactory for most hydrological applications, are acceptable for this type of analysis. Another assumption of the study is that by standardizing input layers and other model creation procedures, one can effectively isolate HRU size as a variable. Although it may be true that this works well when comparing different size classes within one basin, comparing ranges across basins, as is done in Table 8, may be less robust. The variation in sources of error illustrated by the water balance sums (Table 6) and the hydrographs (Figures 8 through 13) may compromise inter-basin comparability. Comparisons within a single basin, however, should be unaffected by this.

The minimum HRU size of $4 \mathrm{~km}^{2}$ was another study limitation. A few previous studies had identified an HRU size of as small as 1-km as being most effective, and many studies included HRUs much smaller than that. This study did not consider HRUs this small; its results might have been different if it had. Also, as discussed above, range of goodness-of-fit scores, especially for NSE and PB, may be an unreliable measure of HRU size sensitivity. Finally, the correlations between goodness-of-fit ranges and basin characteristics are intriguing, but the study does not allow for any definite conclusions as to the cause of geographic variability in in these ranges. 


\section{Conclusions}

The most important result of this study, and the answer to research Questions 1 and 2 above, is that there is no indication that HRU size has a consistent, significant effect on semi-distributed model performance across most mountainous basins in the western US. While this finding may not reveal an optimal HRU size, it may explain the inconsistency in the results of previous studies, as cited in Table 1. Users of PRMS and similar semidistributed models would thus be advised to keep HRU schemes relatively coarse and simple. This has the benefit of reducing model processing time and the number of degrees of freedom, and of allowing modelers to focus on other, more influential aspects of model development. Intuitively, it often seems that a model with more subdivisions should be a better representation of reality and should perform better, but these results indicate that there may be very little pay-off for the increased complexity and overhead of a more highly subdivided model.

This does not indicate, however, that spatially coarse models are generally preferable to fully distributed models. PRMS is more distributed with increased subdivison, but it is still very different from a fully distributed model. Even the smallest HRUs used in this study are much larger the cells in most distributed models, and moreover, routing and instream processes were not included in this study (PRMS does have an optional routing module, but it was not used). Routing and in-stream processes add realism to a model, and require a finer level of spatial detail. Thus, this study does not indicate that complex, fully distributed, grid-based models are not justified. Fully distributed models can be quite powerful, and will always have their place. This study merely demonstrates that in 
at least one semi-distributed model, increased subdivision has little influence over the goodness of fit of daily streamflow at the mouth of the basin. Despite this minimal influence, results do include some interesting geographic patterns. Cartographic display of the range of goodness of fit scores by basin suggests that the western and especially northwestern basins are somewhat less sensitive to hydrological model subdivision. Moran's I analysis shows that this clustered pattern is likely significant, but since this is a global statistic, it is not clear if the statistically significant cluster is located in that exact region.

If the northwestern basins are less sensitive to HRU size, it could be driven by the high levels of precipitation in this region. Spearman's rho correlations among goodnessof-fit ranges and various basin characteristics revealed that high levels of precipitation are associated with lower sensitivity to HRU size. This may be because of the higher spatial uniformity of the synoptic-scale frontal systems that deliver most precipitation in the wettest basins. This suggests that although coarsely subdivided PRMS models may be adequate in moist areas, more highly subdivided HRUs may be appropriate in areas with convective, spatially heterogeneous weather patterns. The lower HRU size sensitivity in this region could also be driven by its lower elevations. In higher elevation areas, it may be more critical to subdivide the basin to distinguish between source and non-source areas.

This study could be improved in a number of ways. First and foremost, the models could be calibrated using a consistent automatic calibration procedure. Once models are better fitted to the historic data, the untested assumption that variation in models with 
poor performance is relevant to better performing models would no longer be required. Care would have to be taken, though, to ensure that the calibration did not interfere with model comparability. Each of the six versions of the same basin could theoretically arrive at different parameter sets with a different performance score via stochastic processes, and this variation could distort or mask variability to HRU size. The best way to avoid this problem, while limited the amount of processing time required, would be to only calibrate one version of each basin. HRU size class 4 could be used, for example. The optimal parameter sets could then be applied to all other delineations of the basin. (One calibration parameter value is used for the entire basin, not each HRU, so this is possible.) Another way of dealing with the stochastic approach would be to calibrate one model numerous times to see if its optimal parameter values were consistent. A few consistent results could still be caused by chance, however; the problem of equifinality is hard to avoid in hydrological models.

One way to control for equifinality in calibration would be to use only a few calibration parameters. Based on the hydrographs (Figures 8 through 13), these should include parameters that affect ET, snow pack formation and melt, and speed of groundwater flow. Even after calibration, however, those basins in which the precipitation input depths are lower than the runoff depth are not likely to perform well. These basins could reasonably be dropped from further investigations due to this poor fit.

One interesting extension would be to consider HRU size sensitivity separately for the wet and dry seasons. If the northwestern basins showed significantly higher HRU size sensitivity in summer than winter, it would provide evidence that spatial variability in 
climate inputs (i.e., convective weather patterns) leads to increased HRU size sensitivity in summer.

Another possible improvement would be to consider components of the hydrologic cycle other than runoff, such as ET or snow-water equivalent. Conducting a similar experiment with another hydrologic model and comparing its finding to this study would also be very informative, as it would allow for insight as to which of these findings are universal, and which are artifacts of PRMS structure. Finally, now that the question of the importance of HRU size in PRMS has been answered (albeit with caveats), it would be interesting to use a similar approach to find which GIS input layers are most effective for parameterization across a range of basins. 


\section{Bibliography}

Abatzoglou, J. T. 2011. Development of gridded surface meteorological data for ecological applications and modelling. International Journal of Climatology. http://doi.wiley.com/10.1002/joc.3413 (last accessed 4 November 2012).

Anselin, L., I. Syabri, and K. Youngihn. 2006. GeoDa: An Introduction to Spatial Data Analysis. Geographical Analysis 38 (1): 5-22.

Arabi, M., R. S. Govindaraju, M. M. Hantush, and B. a. Engel. 2006. Role of Watershed Subdivision on Modeling the Effectiveness of Best Management Practices with SWAT. Journal of the American Water Resources Association 42 (2):513-528. http://doi.wiley.com/10.1111/j.1752-1688.2006.tb03854.x (last accessed 4 November 2011).

Bae, D., I.-W. Jung, and H. Chang. 2008. Potential changes in Korean water resources estimated by high-resolution climate simulation. Climate Research 35:213-226. http://www.int-res.com/abstracts/cr/v35/n3/p213-226/ (last accessed 30 December 2012).

Barnett, T. P., D. W. Pierce, H. G. Hidalgo, C. Bonfils, B. D. Santer, T. Das, G. Bala, A. W. Wood, T. Nozawa, A. A. Mirin, D. R. Cayan, and M. D. Dettinger. 2008. Human-induced changes in the hydrology of the western United States. Science 319 (5866):1080-1083. http://www.ncbi.nlm.nih.gov/pubmed/18239088 (last accessed 7 November 2012). 
Beckers, J., B. Smerdon, and M. Wilson. 2009. Review of hydrologic models for forest management and climate change applications in British Columbia and Alberta. Kamloops, British Columbia, Canada: FORREX-Forum for Research and Extension in Natural Resources. www.forrex.org/publications/forrexseries/fs25.pdf (last accessed 5 November 2011).

Beven, K. 1993. Prophecy, reality and uncertainty in distributed hydrological modelling. Advances in Water Resources 16 (1):41-51. http://linkinghub.elsevier.com/retrieve/pii/030917089390028E.

—. 2001. Dalton Medal Lecture: How far can we go in distributed hydrological modelling? Hydrology and Earth System Sciences 5.1:1-12. 2006. A manifesto for the equifinality thesis. Journal of Hydrology 320 (12):18-36. http://linkinghub.elsevier.com/retrieve/pii/S002216940500332X (last accessed 12 March 2012).

Bingner, R. L., J. Garbrecht, J. G. Arnold, and R. Srinivasan. 1997. Effect of watershed subdivision on simulation runoff and fine sediment yield. Transactions of the ASAE 40 (5):1329-1335. http://cat.inist.fr/?aModele=afficheN\&cpsidt=2117916 (last accessed 5 January 2013). 
Burlando, P., and R. Rosso. 2002. Effects of transient climate change on basin hydrology.

2. Impacts on runoff variability in the Arno River, central Italy. Hydrological Processes 16 (6):1177-1199. http://doi.wiley.com/10.1002/hyp.1056 (last accessed 5 November 2011).

Chang, H., and I.-W. Jung. 2010. Spatial and temporal changes in runoff caused by climate change in a complex large river basin in Oregon. Journal of Hydrology $388(3-4): 186-207$. http://linkinghub.elsevier.com/retrieve/pii/S0022169410002398 (last accessed 24 August 2011).

Cho, J., R. R. Lowrance, D. D. Bosch, T. C. Strickland, Y. Her, and G. Vellidis. 2010. Effect of Watershed Subdivision and Filter Width on SWAT Simulation of a Coastal Plain Watershed. JAWRA Journal of the American Water Resources Association 46 (3):586-602. http://doi.wiley.com/10.1111/j.17521688.2010.00436.x (last accessed 4 November 2011).

Daniel, E. B., J. V Camp, E. J. Leboeuf, J. R. Penrod, J. P. Dobbins, and M. D. Abkowitz. 2011. Watershed Modeling and its Applications: A State-of-the-Art Review. The Open Hydrology Journal 5:26-50.

Dingman, S.L. 2002. Physical Hydrology, Second Edition. Prentice Hall, Upper Saddle River, New Jersey. 
Duan, Q., S. Sorooshian, and V. Gupta. 1994. Optimal use of the SCE-UA global optimization method for calibrating watershed models. Journal of Hydrology $158: 265-284$.

http://www.sciencedirect.com/science/article/pii/0022169494900574 (last accessed 27 December 2012).

Ely, D. M., and J. C. Risley. 2001. Use of a Precipitation-Runoff Model to Simulate Natural Streamflow Conditions in the Methow River Basin, Washington. Tacoma, Washington. http://pubs.usgs.gov/wri/wri014198/pdf/wri014198.pdf.

Esri. 2012. ArcGIS Desktop: Release 10.1. Redlands, CA: Environmental Systems Research Institute.

Falcone, J., D. Carlisle, D. Wolock, and M. Meador. 2010a. GAGES: A stream gage database for evaluating natural and altered flow conditions in the conterminous United States. Ecology 91 (2):621. http://www.esajournals.org/doi/pdf/10.1890/09-0889.1 (last accessed 30 December 2012).

FitzHugh, T. W., and D. S. Mackay. 2000. Impacts of input parameter spatial aggregation on an agricultural nonpoint source pollution model. Journal of Hydrology 236 (12):35-53. http://linkinghub.elsevier.com/retrieve/pii/S0022169400002766. 
Gesch, D., M. Oimoen, S. Greenlee, C. Nelson, M. Steuck, and D. Tyler. 2002. The National Elevation Dataset. Photogrammetric Engineering and Remote Sensing 68 (1):99-118.

Hamon, W. R. 1961. Estimating potential evapotranspiration. Proceedings of the American Society of Civil Engineers 87:107-120.

Harr, R. D. 1982. Fog drip in the Bull Run Municipal Watershed, Oregon. Water Resources Bulletin, 18:785-789.

Hart, D., P. Schoephoester, and K. Bradbury. 2009. Groundwater recharge in Dane County, Wisconsin, estimated by a GIS-based water-balance model. Madison, Wisconsin. http://www.wisconsingeologicalsurvey.org/wofrs/WOFR2009-01.pdf (last accessed 5 November 2011).

Hay, L. E., G. J. McCabe, M. P. Clark, and J. C. Risley. 2009. Reducing Streamflow Forecast Uncertainty: Application and Qualitative Assessment of the Upper Klamath River Basin, Oregon. JAWRA Journal of the American Water Resources Association 45 (3):580-596. http://doi.wiley.com/10.1111/j.17521688.2009.00307.x (last accessed 5 December 2012). 
Homer, C., J. Dewitz, J. Fry, M. Coan, N. Hossain, C. Larson, N. Herold, A. McKerrow, J. N. VanDriel, and J. Wickham. 2007. Completion of the 2001 National Land Cover Database for the Conterminous United States. Photogrammetric Engineering \& Remote Sensing 73 (4):337-341. http://www.epa.gov/mrlc/pdf/april-07-highlight.pdf (last accessed 31 December 2012).

Hunt, C. 1979. National Atlas of the United States of America - Surficial Geology. U.S. Geological Survey. NAC-P-0204-75M-O [map].

IBM Corp. 2011. IBM SPSS Statistics for Windows, Version 20.0. Armonk, NY: IBM Corp.

Jha, M., P. W. Gassman, S. Secchi, R. Gu, and J. Arnold. 2004. Effect of Watershed Subdivision on SWAT Flow, Sediment, and Nutrient Predictions. Journal of the American Water Resources Association 40 (3):811-825. http://doi.wiley.com/10.1111/j.1752-1688.2004.tb04460.x.

Jung, I.-W., D. H. Bae, and B. J. Lee. 2012. Possible change in Korean streamflow seasonality based on multi-model climate projections. Hydrological Processes. http://doi.wiley.com/10.1002/hyp.9215 (last accessed 22 June 2012). 
Jung, I.-W., and H. Chang. 2011. Assessment of future runoff trends under multiple climate change scenarios in the Willamette River Basin, Oregon, USA. Hydrological Processes 25 (2):258-277. http://doi.wiley.com/10.1002/hyp.7842 (last accessed 12 July 2011).

Kern, J. S. 2010. Soils, 800-m dataset, conterminous USA. http://app.databasin.org/app/pages/galleryPage.jsp?id=4f1684c8b8264c49a6e114f 547a7b492 (last accessed 9 January 2013).

Knight, C. G., H. Chang, M. Staneva, and D. Kostov. 2001. A simplified basin model for simulating runoff: The Struma River GIS. Professional Geographer 53(4): $533-$ 545.

Kruskal, W., and W. Wallis. 1952. Use of ranks in one-criterion variance analysis. Journal of the American Statistical Association 47 (260):583-621. http://www.tandfonline.com/doi/abs/10.1080/01621459.1952.10483441 (last accessed 2 January 2013).

Kumar, S., and V. Merwade. 2009. Impact of Watershed Subdivision and Soil Data Resolution on SWAT Model Calibration and Parameter Uncertainty. JAWRA Journal of the American Water Resources Association 45 (5):1179-1196. http://doi.wiley.com/10.1111/j.1752-1688.2009.00353.x (last accessed 16 October 2011). 
Lacroix, M. P. 1999. Spatial scale and hydrological model response. Dissertation. University of Saskatchewan. http://library.usask.ca/theses/available/etd06222012-132109/ (last accessed 27 December 2012).

Leavesley, G. H., and L. G. Stannard. 1995. Chapter 9: The precipitation-runoff modeling system-PRMS. In Computer models of watershed hydrology. Littleton, Colorado: Water Resources Publications.

Leavesley, G., R. Lichty, B. Troutman, and L. Saindon. 1983. Precipitation-runoff modeling system: User's manual Water-Resources Investigations Report 83-4238: US Geological Survey. http://pubs.usgs.gov/wri/1983/4238/report.pdf (last accessed 30 December 2012).

Legates, D., and T. DeLiberty. 1993. Precipitation measurement biases in the United States. Water Resources Bulletin 29 (5):855-861.

Legesse, D., C. Valletcoulomb, and F. Gasse. 2003. Hydrological response of a catchment to climate and land use changes in Tropical Africa: case study South Central Ethiopia. Journal of Hydrology 275 (1-2):67-85. http://linkinghub.elsevier.com/retrieve/pii/S0022169403000192 (last accessed 25 July 2011). 
Mamillapalli, S., R. Srinivasan, J. Arnold, and B. A. Engel. 1996. Effect of spatial variability on basin scale modeling. In Proceedings, Third International Conference/Workshop on Integrating GIS and Environmental Modeling, Santa Fe, New Mexico, January, 1996.

http://www.ncgia.ucsb.edu/conf/SANTA_FE_CDROM/sf_papers/mamillapalli_sudhakar/my_paper.html (last accessed 16 October 2011).

Markham, C. G. 1970. Seasonality of Precipitation in the United States. Annals of the Association of American Geographers 60 (3):593-597. http://www.tandfonline.com/doi/abs/10.1111/j.1467-8306.1970.tb00743.x.

Markstrom, S. L., R. G. Niswonger, R. S. Regan, D. E. Prudic, and P. M. Barlow. 2005. GSFLOW - Coupled Ground-Water and Surface-Water Flow Model Based on the Integration of the Precipitation-Runoff Modeling System (PRMS) and the Modular Ground-Water Flow Model (MODFLOW-2005). http://pubs.usgs.gov/tm/tm6d1/pdf/tm6d1.pdf (last accessed 5 January 2013).

McCabe, G., and D. Wolock. 2010. Long-term variability in Northern Hemisphere snow cover and associations with warmer winters. Climatic Change 99 (1-2):141-153 LA - English. http://dx.doi.org/10.1007/s10584-009-9675-2. 
Muleta, M. K., J. W. Nicklow, and E. G. Bekele. 2007. Sensitivity of a Distributed Watershed Simulation Model to Spatial Scale. Journal of Hydrologic Engineering 12 (2):163. http://link.aip.org/link/JHYEFF/v12/i2/p163/s1\&Agg=doi. (last accessed 5 January 2013).

Nash, J., and J. Sutcliffe. 1970. River Flow Forecasting through Conceptual Models. Journal of hydrology 10 (3):282-290. http://www.sciencedirect.com/science/article/pii/0022169470902556 (last accessed 5 November 2011).

Norris, G., and C. Haan. 1993. Impact of subdividing watersheds on estimated hydrographs. Applied Engineering in Agriculture 9 (5):443-445. http://cleveland2.ce.ttu.edu/documents/copyright/NAUTHORS/AP_AG_ENGR_1993/norris_haan.pdf(last accessed 29 December 2012).

Nour, M. H., D. W. Smith, M. G. El-Din, and E. E. Prepas. 2008. Effect of watershed subdivision on water-phase phosphorus modelling: An artificial neural network modelling application. Journal of Environmental Engineering and Science 7 (Suppl. 1):S95-S108. http://www.nrcresearchpress.com/doi/abs/10.1139/S08-043 (last accessed 4 November 2011).

O’Sullivan, D., and D. J. Unwin. 2010. Geographic Information Analysis. Hoboken, New Jersey: John Wiley \& Sons, Inc. 
Qi, S., G. Sun, Y. Wang, S. G. McNulty, and J. A. Moore Myers. 2009. Streamflow Response to Climate and Landuse Changes in a Coastal Watershed in North Carolina. Transactions of the ASABE 52 (3):739-749.

http://www.srs.fs.usda.gov/pubs/ja/ja_sun028.pdf(last accessed 16 October 2011).

Reed, J.C. and Bush, C.A., 2001, Generalized geologic map of the United States, Puerto Rico, and the U.S. Virgin Islands, [digital maps], Version 2.0, posted December 2005, accessed September 28, 2010, at http://pubs.usgs.gov/atlas/geologic/.

Smerdon, B., D. Allen, S. Grasby, and M. Berg. 2009. An approach for predicting groundwater recharge in mountainous watersheds. Journal of Hydrology 365 (34):156-172. http://linkinghub.elsevier.com/retrieve/pii/S0022169408005532 (last accessed 18 July 2011).

Song, Z., and L. D. James. 1992. An Objective Test for Hydrologic Scale. JAWRA Journal of the American Water Resources Association 28 (5):833-844. http://dx.doi.org/10.1111/j.1752-1688.1992.tb03185.x.

Surfleet, C. G., D. Tullos, H. Chang, and I.-W. Jung. 2012. Selection of hydrologic modeling approaches for climate change assessment: A comparison of model scale and structures. Journal of Hydrology 464-465:233-248. http://linkinghub.elsevier.com/retrieve/pii/S0022169412005884 (last accessed 29 November 2012). 
Tripathi, M. P., N. S. Raghuwanshi, and G. P. Rao. 2006. Effect of watershed subdivision on simulation of water balance components. Hydrological Processes 20 (5):11371156. http://doi.wiley.com/10.1002/hyp.5927 (last accessed 18 October 2011).

USDA-NRCS (US Department of Agriculture - Natural Resources Conservation Services). US General Soil Map (STATSGO2). GIS dataset. http://soildatamart.nrcs.usda.gov/ (last accessed 5 January 2013).

USGS (US Geological Survey). 2012. Updates to the PRMS Modules for Version 3.0.0. Technical document. 34 pages. ftp://brrftp.cr.usgs.gov/pub/mows/software/prms/3.0.2/updatesSinceGsflow.pdf (last accessed 5 January 2013).

Viger, R. J., and G. H. Leavesley. 2007. The GIS Weasel user's manual. Techniques and Methods 6-B4. U.S. Department of the Interior, U.S. Geological Survey. http://pubs.usgs.gov/tm/2007/06B04/ (last accessed 16 October 2011).

Willmott, C. J. 1981. On the validation of models. Physical Geography 2:184-194.

Wingfield, M. T. 2008. Effect of Watershed Subdivision and Parameter Selection on Modeling Results. Thesis. Texas Tech University. 114 p. http://cleveland2.ce.ttu.edu/publications/thesis/wingfield_thesis/Wingfield_Matth ew_Thesis.pdf (last accessed 9 January 2013). 
Wolock, D. M., and G. J. McCabe Jr. 1995. Comparison of single and multiple flow direction algorithms for computing topographic parameters in TOPMODEL. Water Resources Research 31 (5):1315-1324.

Wolock, D. M., and G. J. McCabe. 1999. Estimates of Runoff Using Water-Balance and Atmospheric General Circulation Models. JAWRA Journal of the American Water Resources Association 35 (6):1341-1350.

Wood, E. F., M. Sivapalan, K. Beven, and L. Band. 1988. Effects of Spatial Variablity and Scale with Implications to Hydrologic Modeling. Journal of Hydrology 102 $(1-4): 29-47$.

http://www.sciencedirect.com/science/article/pii/002216948890090X (last accessed 4 November 2011).

Zhang, Z., V. Koren, M. Smith, S. Reed, and D. Wang. 2004. Use of next generation weather radar data and basin disaggregation to improve continuous hydrograph simulations. Journal of Hydrologic Engineering 9:103-115. http://ascelibrary.org/doi/abs/10.1061/(ASCE)1084-0699(2004)9\%3A2(103) (last accessed 29 December 2012). 


\section{Appendix A}

GAGES II variables used that were compared to model performance scores. Descriptions are from the dataset's documentation.

\begin{tabular}{|c|c|}
\hline Variable Name & Description \\
\hline AGGECOREGION & Aggregated level II ecoregion used for classification \\
\hline DRAIN_SQKM & Watershed drainage area, $\mathrm{sq} \mathrm{km}$, as delineated in our basin boundary \\
\hline DRAIN_SQKM & $\begin{array}{l}\text { Watershed drainage area, sq km, as delineated in our basin boundary (this is the same as } \\
\text { what is in the BasinID worksheet, but is duplicated here for convenient comparison to } \\
\text { NWIS_DRAIN_SQKM) }\end{array}$ \\
\hline $\begin{array}{l}\text { HYDRO_DISTURB_IN } \\
\text { DX }\end{array}$ & $\begin{array}{l}\text { Hydrologic "disturbance index" score, based on } 7 \text { variables: 1) MAJ_DDENS_2009, 2) } \\
\text { WATER_WITHDR, 3) change in dam storage 1950-2009, 4) CANALS_PCT, 5) } \\
\text { RAW_DIS_NEAREST_MAJ_NPDES, 6) ROADS_KM_SQ_KM, and 7) FRAGUN_BASIN. } \\
\text { Low values = low anthropogenic hydrologic modification in the watershed, high values = high } \\
\text { anthropogenic hydrologic modification }\end{array}$ \\
\hline BAS_COMPACTNESS & $\begin{array}{l}\text { Watershed compactness ratio, }=\text { area/perimeter }{ }^{\wedge} * 100 ; \text { higher number }=\text { more compact } \\
\text { shape. }\end{array}$ \\
\hline LAT_CENT & Latitude of centroid location of basin, decimal degrees \\
\hline LONG_CENT & Longitude of centroid location of basin, decimal degrees \\
\hline PPTAVG_BASIN & $\begin{array}{l}\text { Mean annual precip (cm) for the watershed, from } 800 \mathrm{~m} \text { PRISM data. } 30 \text { years period of } \\
\text { record } 1971-2000 \text {. }\end{array}$ \\
\hline T_AVG_BASIN & $\begin{array}{l}\text { Average annual air temperature for the watershed, degrees C, from 2km PRISM data. } 30 \\
\text { years period of record 1971-2000. }\end{array}$ \\
\hline T_MAX_BASIN & $\begin{array}{l}\text { Watershed average of maximum monthly air temperature (degrees C) from 800m PRISM, } \\
\text { derived from } 30 \text { years of record (1971-2000). }\end{array}$ \\
\hline T_MAXSTD_BASIN & $\begin{array}{l}\text { Standard deviation of maximum monthly air temperature (degrees C) from 800m PRISM, } \\
\text { derived from } 30 \text { years of record (1971-2000). }\end{array}$ \\
\hline T_MIN_BASIN & $\begin{array}{l}\text { Watershed average of minimum monthly air temperature (degrees C) from 800m PRISM, } \\
\text { derived from } 30 \text { years of record (1971-2000). }\end{array}$ \\
\hline T_MINSTD_BASIN & $\begin{array}{l}\text { Standard deviation of minimum monthly air temperature (degrees C) from 800m PRISM, } \\
\text { derived from } 30 \text { years of record (1971-2000). }\end{array}$ \\
\hline RH_BASIN & $\begin{array}{l}\text { Watershed average relative humidity (percent), from } 2 \mathrm{~km} \text { PRISM, derived from } 30 \text { years of } \\
\text { record (1961-1990). }\end{array}$ \\
\hline FST32F_BASIN & $\begin{array}{l}\text { Watershed average of mean day of the year of first freeze, derived from } 30 \text { years of record } \\
\text { (1961-1990), 2km PRISM. For example, value of } 300 \text { is the } 300 \text { th day of the year (Oct 27th). }\end{array}$ \\
\hline LST32F_BASIN & $\begin{array}{l}\text { Watershed average of mean day of the year of last freeze, derived from } 30 \text { years of record } \\
\text { (1961-1990), 2km PRISM. For example, value of } 100 \text { is the 100th day of the year (April } \\
\text { 10th). }\end{array}$ \\
\hline WD_BASIN & $\begin{array}{l}\text { Watershed average of annual number of days (days) of measurable precipitation, derived } \\
\text { from } 30 \text { years of record (1961-1990), 2km PRISM. }\end{array}$ \\
\hline WDMAX_BASIN & $\begin{array}{l}\text { Watershed average of monthly maximum number of days (days) of measurable precipitation, } \\
\text { derived from } 30 \text { years of record (1961-1990), 2km PRISM. }\end{array}$ \\
\hline WDMIN_BASIN & $\begin{array}{l}\text { Watershed average of monthly minimum number of days (days) of measurable precipitation, } \\
\text { derived from } 30 \text { years of record (1961-1990), } 2 \mathrm{~km} \text { PRISM. }\end{array}$ \\
\hline PET & $\begin{array}{l}\text { Mean-annual potential evapotranspiration (PET), estimated using the Hamon (1961) } \\
\text { equation. }\end{array}$ \\
\hline SNOW_PCT_PRECIP & $\begin{array}{l}\text { Snow percent of total precipitation estimate, mean for period 1901-2000. From McCabe and } \\
\text { Wolock (2010), 1km grid. }\end{array}$ \\
\hline
\end{tabular}




\begin{tabular}{|c|c|}
\hline Variable Name & Description \\
\hline PRECIP_SEAS_IND & $\begin{array}{l}\text { Precipitation seasonality index (Markham, 1970; Dingman, 2002). Index of how much } \\
\text { annual precipitation falls seasonally (high values) or spread out over the year (low values). } \\
\text { Based on monthly precip values from } 30 \text { year (1971-2000) PRISM. Range is } 0 \text { (precip } \\
\text { spread out exactly evenly in each month) to } 1 \text { (all precip falls in a single month). }\end{array}$ \\
\hline JAN_PPT7100_CM & $\begin{array}{l}\text { Mean January precip }(\mathrm{cm}) \text { for the watershed, from } 800 \mathrm{~m} \text { PRISM data. } 30 \text { years period of } \\
\text { record } 1971-2000 \text {. }\end{array}$ \\
\hline FEB_PPT7100_CM & $\begin{array}{l}\text { Mean February precip (cm) for the watershed, from } 800 \mathrm{~m} \text { PRISM data. } 30 \text { years period of } \\
\text { record } 1971-2000 \text {. }\end{array}$ \\
\hline MAR_PPT7100_CM & $\begin{array}{l}\text { Mean March precip }(\mathrm{cm}) \text { for the watershed, from 800m PRISM data. } 30 \text { years period of } \\
\text { record 1971-2000. }\end{array}$ \\
\hline APR_PPT7100_CM & $\begin{array}{l}\text { Mean April precip }(\mathrm{cm}) \text { for the watershed, from } 800 \mathrm{~m} \text { PRISM data. } 30 \text { years period of record } \\
1971-2000 \text {. }\end{array}$ \\
\hline MAY_PPT7100_CM & $\begin{array}{l}\text { Mean May precip }(\mathrm{cm}) \text { for the watershed, from } 800 \mathrm{~m} \text { PRISM data. } 30 \text { years period of record } \\
1971-2000 \text {. }\end{array}$ \\
\hline JUN_PPT7100 CM & $\begin{array}{l}\text { Mean June precip }(\mathrm{cm}) \text { for the watershed, from } 800 \mathrm{~m} \text { PRISM data. } 30 \text { years period of } \\
\text { record } 1971-2000 \text {. }\end{array}$ \\
\hline JUL_PPT7100_CM & $\begin{array}{l}\text { Mean July precip }(\mathrm{cm}) \text { for the watershed, from } 800 \mathrm{~m} \text { PRISM data. } 30 \text { years period of record } \\
1971-2000 \text {. }\end{array}$ \\
\hline AUG_PPT7100_CM & $\begin{array}{l}\text { Mean August precip }(\mathrm{cm}) \text { for the watershed, from } 800 \mathrm{~m} \text { PRISM data. } 30 \text { years period of } \\
\text { record } 1971-2000 \text {. }\end{array}$ \\
\hline SEP_PPT7100_CM & $\begin{array}{l}\text { Mean September precip }(\mathrm{cm}) \text { for the watershed, from } 800 \mathrm{~m} \text { PRISM data. } 30 \text { years period of } \\
\text { record } 1971-2000 \text {. }\end{array}$ \\
\hline OCT_PPT7100_CM & $\begin{array}{l}\text { Mean October precip }(\mathrm{cm}) \text { for the watershed, from 800m PRISM data. } 30 \text { years period of } \\
\text { record 1971-2000. }\end{array}$ \\
\hline NOV_PPT7100_CM & $\begin{array}{l}\text { Mean November precip }(\mathrm{cm}) \text { for the watershed, from } 800 \mathrm{~m} \text { PRISM data. } 30 \text { years period of } \\
\text { record } 1971-2000 \text {. }\end{array}$ \\
\hline DEC_PPT7100_CM & $\begin{array}{l}\text { Mean December precip }(\mathrm{cm}) \text { for the watershed, from } 800 \mathrm{~m} \text { PRISM data. } 30 \text { years period of } \\
\text { record } 1971-2000 \text {. }\end{array}$ \\
\hline JAN_TMP7100_DEGC & $\begin{array}{l}\text { Average January air temperature for the watershed, degrees C, from } 800 \mathrm{~m} \text { PRISM data. } 30 \\
\text { years period of record } 1971-2000 \text {. }\end{array}$ \\
\hline FEB_TMP7100_DEGC & $\begin{array}{l}\text { Average February air temperature for the watershed, degrees C, from } 800 \mathrm{~m} \text { PRISM data. } 30 \\
\text { years period of record } 1971-2000 \text {. }\end{array}$ \\
\hline $\begin{array}{l}\text { MAR_TMP7100_DEG } \\
\text { C }\end{array}$ & $\begin{array}{l}\text { Average March air temperature for the watershed, degrees C, from 800m PRISM data. } 30 \\
\text { years period of record 1971-2000. }\end{array}$ \\
\hline $\begin{array}{l}\text { APR_TMP7100_DEG } \\
\text { C }\end{array}$ & $\begin{array}{l}\text { Average April air temperature for the watershed, degrees C, from 800m PRISM data. } 30 \\
\text { years period of record 1971-2000. }\end{array}$ \\
\hline $\begin{array}{l}\text { MAY_TMP7100_DEG } \\
\text { C }\end{array}$ & $\begin{array}{l}\text { Average May air temperature for the watershed, degrees C, from 800m PRISM data. } 30 \\
\text { years period of record } 1971-2000 \text {. }\end{array}$ \\
\hline JUN_TMP7100_DEGC & $\begin{array}{l}\text { Average June air temperature for the watershed, degrees C, from } 800 \mathrm{~m} \text { PRISM data. } 30 \\
\text { years period of record } 1971-2000 \text {. }\end{array}$ \\
\hline JUL_TMP7100_DEGC & $\begin{array}{l}\text { Average July air temperature for the watershed, degrees C, from 800m PRISM data. } 30 \\
\text { years period of record } 1971-2000 \text {. }\end{array}$ \\
\hline $\begin{array}{l}\text { AUG_TMP7100_DEG } \\
\text { C }\end{array}$ & $\begin{array}{l}\text { Average August air temperature for the watershed, degrees C, from } 800 \mathrm{~m} \text { PRISM data. } 30 \\
\text { years period of record } 1971-2000 \text {. }\end{array}$ \\
\hline $\begin{array}{l}\text { SEP_TMP7100_DEG } \\
\text { C }\end{array}$ & $\begin{array}{l}\text { Average September air temperature for the watershed, degrees C, from } 800 \mathrm{~m} \text { PRISM data. } \\
30 \text { years period of record } 1971-2000 \text {. }\end{array}$ \\
\hline $\begin{array}{l}\text { OCT_TMP7100_DEG } \\
\text { C }\end{array}$ & $\begin{array}{l}\text { Average October air temperature for the watershed, degrees C, from } 800 \mathrm{~m} \text { PRISM data. } 30 \\
\text { years period of record } 1971-2000 \text {. }\end{array}$ \\
\hline $\begin{array}{l}\text { NOV_TMP7100_DEG } \\
\text { C }\end{array}$ & $\begin{array}{l}\text { Average November air temperature for the watershed, degrees C, from } 800 \mathrm{~m} \text { PRISM data. } \\
30 \text { years period of record } 1971-2000 \text {. }\end{array}$ \\
\hline $\begin{array}{l}\text { DEC_TMP7100_DEG } \\
\text { C }\end{array}$ & $\begin{array}{l}\text { Average December air temperature for the watershed, degrees } C \text {, from } 800 \mathrm{~m} \text { PRISM data. } \\
30 \text { years period of record } 1971-2000 \text {. }\end{array}$ \\
\hline
\end{tabular}




\begin{tabular}{|c|c|}
\hline Variable Name & Description \\
\hline $\begin{array}{l}\text { GEOL_REEDBUSH_D } \\
\text { OM }\end{array}$ & $\begin{array}{l}\text { Dominant (highest percent of area) geology, derived from a simplified version of Reed \& } \\
\text { Bush (2001) - Generalized Geologic Map of the Conterminous United States. }\end{array}$ \\
\hline $\begin{array}{l}\text { GEOL_HUNT_DOM_C } \\
\text { ODE }\end{array}$ & Dominant (highest percent of area) geology, derived from Hunt (1979) coverage \\
\hline FRAGUN_BASIN & $\begin{array}{l}\text { Fragmentation Index of "undeveloped" land in the watershed. High numbers = more } \\
\text { disturbance by development and fragmentation; a very pristine basin with a lot of contiguous } \\
\text { undeveloped land cover would have a low number }\end{array}$ \\
\hline HIRES_LENTIC_NUM & Number of Lakes/Ponds + Reservoir water bodies from NHD Hi-Resolution (1:24k) data \\
\hline $\begin{array}{l}\text { HIRES_LENTIC_DEN } \\
\text { S }\end{array}$ & $\begin{array}{l}\text { Density (\#/sq km) of Lakes/Ponds + Reservoir water bodies from NHD Hi-Resolution (1:24k) } \\
\text { data }\end{array}$ \\
\hline $\begin{array}{l}\text { HIRES_LENTIC_MEA } \\
\text { NSIZ }\end{array}$ & $\begin{array}{l}\text { Mean size (ha) of Lakes/Ponds + Reservoir water bodies from NHD Hi-Resolution (1:24k) } \\
\text { data }\end{array}$ \\
\hline $\begin{array}{l}\text { STREAMS_KM_SQ_K } \\
\text { M }\end{array}$ & Stream density, $\mathrm{km}$ of streams per watershed $\mathrm{sq} \mathrm{km}$, from NHD 100k streams \\
\hline STRAHLER_MAX & Maximum Strahler stream order in watershed, from NHDPlus. \\
\hline $\begin{array}{l}\text { MAINSTEM_SINUOU } \\
\text { SITY }\end{array}$ & $\begin{array}{l}\text { Sinuosity of mainstem stream line, from our delineation of mainstem stream lines (see } \\
\text { Falcone et al., 2010). Defined as curvilinear length of the mainstem stream line divided by } \\
\text { the straight-line distance between the end points of the line. }\end{array}$ \\
\hline ARTIFPATH_PCT & $\begin{array}{l}\text { Percent of stream kilometers coded as "Artificial Path" in NHDPlus. Note this does not } \\
\text { necessarily mean the stream is modified, only that it is wide enough to be represented as a } \\
\text { polygon rather than a line. In some cases this is indicative of damming. }\end{array}$ \\
\hline $\begin{array}{l}\text { ARTIFPATH_MAINST } \\
\text { EM_PCT }\end{array}$ & $\begin{array}{l}\text { Percent of mainstem stream(s) coded as "Artificial Path" in NHDPlus., from our delineation } \\
\text { of mainstem streamlines. Note this does not necessarily mean the stream is modified, only } \\
\text { that it is wide enough to be represented as a polygon rather than a line. In some cases this } \\
\text { is indicative of damming. }\end{array}$ \\
\hline HIRES_LENTIC_PCT & $\begin{array}{l}\text { Percent of watershed surface area covered by "Lakes/Ponds" + "Reservoirs" in NHD Hi- } \\
\text { Resolution (1:24k) data }\end{array}$ \\
\hline BFI_AVE & $\begin{array}{l}\text { Base Flow Index (BFI), The BFI is a ratio of base flow to total streamflow, expressed as a } \\
\text { percentage and ranging from } 0 \text { to } 100 \text {. Base flow is the sustained, slowly varying component } \\
\text { of streamflow, usually attributed to ground-water discharge to a stream. }\end{array}$ \\
\hline PERDUN & $\begin{array}{l}\text { Dunne overland flow, also know as saturation overland flow, is generated in a basin when } \\
\text { the water table "outcrops" on the land surface (due to the infiltration and redistribution of soil } \\
\text { moisture within the basin), thereby producing temporary saturated areas. These saturated } \\
\text { areas generate Dunne overland flow through exfiltration of shallow ground water and by } \\
\text { routing precipitation directly to the stream network. }\end{array}$ \\
\hline PERHOR & $\begin{array}{l}\text { Horton overland flow, also known as infiltration-excess overland flow, is generated in a basin } \\
\text { when infiltration rates are exceeded by precipitation rates. }\end{array}$ \\
\hline TOPWET & $\begin{array}{l}\text { Topographic wetness index, In(a/S); where "In" is the natural log, "a" is the upslope area per } \\
\text { unit contour length and "S" is the slope at that point. See } \\
\text { http://ks.water.usgs.gov/Kansas/pubs/reports/wrir.99-4242.html and Wolock and McCabe, } \\
1995 \text { for more detail }\end{array}$ \\
\hline CONTACT & $\begin{array}{l}\text { Subsurface flow contact time index. The subsurface contact time index estimates the } \\
\text { number of days that infiltrated water resides in the saturated subsurface zone of the basin } \\
\text { before discharging into the stream. }\end{array}$ \\
\hline RUNAVE7100 & $\begin{array}{l}\text { Estimated watershed annual runoff, mm/year, mean for the period 1971-2000. Estimation } \\
\text { method integrated effects of climate, land use, water use, regulation, etc. }\end{array}$ \\
\hline WB5100_JAN_MM & $\begin{array}{l}\text { Estimated watershed January runoff, } \mathrm{mm} / \mathrm{month} \text {, mean for the period } 1951-2000 \text {. From } \\
\text { Wolock and McCabe (1999) water balance model. Estimates the effects of precip and } \\
\text { temperature, but not other factors (land use, water use, regulation, etc.) }\end{array}$ \\
\hline WB5100_FEB_MM & $\begin{array}{l}\text { Estimated watershed February runoff, } \mathrm{mm} / \mathrm{month} \text {, mean for the period 1951-2000. From } \\
\text { Wolock and McCabe (1999) water balance model. Estimates the effects of precip and } \\
\text { temperature, but not other factors (land use, water use, regulation, etc.) }\end{array}$ \\
\hline
\end{tabular}




\begin{tabular}{|c|c|}
\hline Variable Name & Description \\
\hline WB5100_MAR_MM & $\begin{array}{l}\text { Estimated watershed March runoff, } \mathrm{mm} / \mathrm{month} \text {, mean for the period 1951-2000. From } \\
\text { Wolock and McCabe (1999) water balance model. Estimates the effects of precip and } \\
\text { temperature, but not other factors (land use, water use, regulation, etc.) }\end{array}$ \\
\hline WB5100_APR_MM & $\begin{array}{l}\text { Estimated watershed April runoff, mm/month, mean for the period } 1951-2000 \text {. From Wolock } \\
\text { and McCabe (1999) water balance model. Estimates the effects of precip and temperature, } \\
\text { but not other factors (land use, water use, regulation, etc.) }\end{array}$ \\
\hline WB5100_MAY_MM & $\begin{array}{l}\text { Estimated watershed May runoff, mm/month, mean for the period 1951-2000. From Wolock } \\
\text { and McCabe (1999) water balance model. Estimates the effects of precip and temperature, } \\
\text { but not other factors (land use, water use, regulation, etc.) }\end{array}$ \\
\hline WB5100_JUN_MM & $\begin{array}{l}\text { Estimated watershed June runoff, } \mathrm{mm} / \mathrm{month} \text {, mean for the period 1951-2000. From Wolock } \\
\text { and McCabe (1999) water balance model. Estimates the effects of precip and temperature, } \\
\text { but not other factors (land use, water use, regulation, etc.) }\end{array}$ \\
\hline WB5100_JUL_MM & $\begin{array}{l}\text { Estimated watershed July runoff, } \mathrm{mm} / \mathrm{month} \text {, mean for the period 1951-2000. From Wolock } \\
\text { and McCabe (1999) water balance model. Estimates the effects of precip and temperature, } \\
\text { but not other factors (land use, water use, regulation, etc.) }\end{array}$ \\
\hline WB5100_AUG_MM & $\begin{array}{l}\text { Estimated watershed August runoff, mm/month, mean for the period } 1951-2000 \text {. From } \\
\text { Wolock and McCabe (1999) water balance model. Estimates the effects of precip and } \\
\text { temperature, but not other factors (land use, water use, regulation, etc.) }\end{array}$ \\
\hline WB5100_SEP_MM & $\begin{array}{l}\text { Estimated watershed September runoff, } \mathrm{mm} / \mathrm{month} \text {, mean for the period } 1951-2000 \text {. From } \\
\text { Wolock and McCabe (1999) water balance model. Estimates the effects of precip and } \\
\text { temperature, but not other factors (land use, water use, regulation, etc.) }\end{array}$ \\
\hline WB5100_OCT_MM & $\begin{array}{l}\text { Estimated watershed October runoff, } \mathrm{mm} / \mathrm{month} \text {, mean for the period } 1951-2000 \text {. From } \\
\text { Wolock and McCabe (1999) water balance model. Estimates the effects of precip and } \\
\text { temperature, but not other factors (land use, water use, regulation, etc.) }\end{array}$ \\
\hline WB5100_NOV_MM & $\begin{array}{l}\text { Estimated watershed November runoff, mm/month, mean for the period 1951-2000. From } \\
\text { Wolock and McCabe (1999) water balance model. Estimates the effects of precip and } \\
\text { temperature, but not other factors (land use, water use, regulation, etc.) }\end{array}$ \\
\hline WB5100_DEC_MM & $\begin{array}{l}\text { Estimated watershed December runoff, } \mathrm{mm} / \mathrm{month} \text {, mean for the period } 1951-2000 \text {. From } \\
\text { Wolock and McCabe (1999) water balance model. Estimates the effects of precip and } \\
\text { temperature, but not other factors (land use, water use, regulation, etc.) }\end{array}$ \\
\hline WB5100_ANN_MM & $\begin{array}{l}\text { Estimated watershed annual runoff, mm/year, mean for the period 1951-2000. From Wolock } \\
\text { and McCabe (1999) water balance model. Estimates the effects of precip and temperature, } \\
\text { but not other factors (land use, water use, regulation, etc.) }\end{array}$ \\
\hline PCT_1ST_ORDER & $\begin{array}{l}\text { Percent of stream lengths in the watershed which are first-order streams (Strahler order); } \\
\text { from NHDPlus }\end{array}$ \\
\hline PCT_2ND_ORDER & $\begin{array}{l}\text { Percent of stream lengths in the watershed which are second-order streams (Strahler order); } \\
\text { from NHDPlus }\end{array}$ \\
\hline PCT_3RD_ORDER & $\begin{array}{l}\text { Percent of stream lengths in the watershed which are third-order streams (Strahler order); } \\
\text { from NHDPlus }\end{array}$ \\
\hline PCT_4TH_ORDER & $\begin{array}{l}\text { Percent of stream lengths in the watershed which are fourth-order streams (Strahler order); } \\
\text { from NHDPlus }\end{array}$ \\
\hline PCT_5TH_ORDER & $\begin{array}{l}\text { Percent of stream lengths in the watershed which are fifth-order streams (Strahler order); } \\
\text { from NHDPlus }\end{array}$ \\
\hline $\begin{array}{l}\text { PCT_6TH_ORDER_O } \\
\text { R_MORE }\end{array}$ & $\begin{array}{l}\text { Percent of stream lengths in the watershed which are sixth or greater-order streams } \\
\text { (Strahler order); from NHDPlus }\end{array}$ \\
\hline PCT_NO_ORDER & $\begin{array}{l}\text { Percent of stream lengths in the watershed which do not have any streamorder in NHDPlus; } \\
\text { these are typically canals, pipelines, and ditches. }\end{array}$ \\
\hline DEVNLCD06 & $\begin{array}{l}\text { Watershed percent "developed" (urban), } 2006 \text { era (2001 for AK-HI-PR). Sum of classes 21, } \\
22,23 \text {, and } 24\end{array}$ \\
\hline FORESTNLCD06 & Watershed percent "forest", 2006 era (2001 for AK-HI-PR). Sum of classes 41, 42, and 43 \\
\hline PLANTNLCD06 & $\begin{array}{l}\text { Watershed percent "planted/cultivated" (agriculture), } 2006 \text { era (2001 for AK-HI-PR). Sum of } \\
\text { classes } 81 \text { and } 82\end{array}$ \\
\hline
\end{tabular}




\begin{tabular}{|c|c|}
\hline Variable Name & Description \\
\hline WATERNLCD06 & Watershed percent Open Water (class 11) \\
\hline SNOWICENLCD06 & Watershed percent Perennial Ice/Snow (class 12) \\
\hline DEVOPENNLCD06 & Watershed percent Developed, Open Space (class 21) \\
\hline DEVLOWNLCD06 & Watershed percent Developed, Low Intensity (class 22) \\
\hline DEVMEDNLCD06 & Watershed percent Developed, Medium Intensity (class 23) \\
\hline DEVHINLCD06 & Watershed percent Developed, High Intensity (class 24) \\
\hline BARRENNLCD06 & Watershed percent Natural Barren (class 31) \\
\hline DECIDNLCD06 & Watershed percent Deciduous Forest (class 41) \\
\hline EVERGRNLCD06 & Watershed percent Evergreen Forest (class 42) \\
\hline MIXEDFORNLCD06 & Watershed percent Mixed Forest (class 43) \\
\hline SHRUBNLCD06 & Watershed percent Shrubland (class 52) \\
\hline GRASSNLCD06 & Watershed percent Herbaceous (grassland) (class 71) \\
\hline PASTURENLCD06 & Watershed percent Pasture/Hay (class 81) \\
\hline CROPSNLCDO6 & Watershed percent Cultivated Crops (class 82) \\
\hline WOODYWETNLCD06 & Watershed percent Woody Wetlands (class 90) \\
\hline EMERGWETNLCD06 & Watershed percent Emergent Herbaceous Wetlands (class 95) \\
\hline PDEN_2000_BLOCK & $\begin{array}{l}\text { Population density in the watershed, persons per } \mathrm{sq} \mathrm{km} \text {, from } 2000 \text { Census block data } \\
\text { regridded to } 100 \mathrm{~m} \text {. This variable is maintained to support models built from original GAGES } \\
\text { dataset. }\end{array}$ \\
\hline $\begin{array}{l}\text { PDEN_DAY_LANDSC } \\
\text { AN_2007 }\end{array}$ & $\begin{array}{l}\text { Population density in the watershed during the day, persons per sq km, from 90-m } 2007 \\
\text { Landscan }\end{array}$ \\
\hline $\begin{array}{l}\text { PDEN_NIGHT_LAND } \\
\text { SCAN_2007 }\end{array}$ & $\begin{array}{l}\text { Population density in the watershed at night (residential population), persons per sq km, } \\
\text { from } 90-\mathrm{m} 2007 \text { Landscan }\end{array}$ \\
\hline ROADS_KM_SQ_KM & Road density, $\mathrm{km}$ of roads per watershed sq km, from Census 2000 TIGER roads \\
\hline RD_STR_INTERS & $\begin{array}{l}\text { Number of road/stream intersections, per km of total basin stream length ( } 2000 \text { TIGER roads } \\
\text { and NHD 100k streams) }\end{array}$ \\
\hline IMPNLCD06 & Watershed percent impervious surfaces from 30-m resolution NLCD06 data \\
\hline NLCD01_06_DEV & $\begin{array}{l}\text { Watershed percent which changed to "Developed" (urban) land (NLCD classes 21-24) } \\
\text { between NLCD } 2001 \text { and } 2006\end{array}$ \\
\hline HGA & $\begin{array}{l}\text { Percentage of soils in hydrologic group A. Hydrologic group A soils have high infiltration } \\
\text { rates. Soils are deep and well drained and, typically, have high sand and gravel content. }\end{array}$ \\
\hline HGB & $\begin{array}{l}\text { Percentage of soils in hydrologic group B. Hydrologic group B soils have moderate infiltration } \\
\text { rates. Soils are moderately deep, moderately well drained, and moderately coarse in texture. }\end{array}$ \\
\hline HGAD & $\begin{array}{l}\text { Percentage of soils in hydrologic group A/D. Hydrologic group A/D soils have group A } \\
\text { characteristics (high infiltration rates) when artificially drained and have group D } \\
\text { characteristics (very slow infiltration rates) when not drained. }\end{array}$ \\
\hline HGC & $\begin{array}{l}\text { Percentage of soils in hydrologic group C. Hydrologic group C soils have slow soil inflitration } \\
\text { rates. The soil profiles include layers impeding downward movement of water and, typically, } \\
\text { have moderately fine or fine texture. }\end{array}$ \\
\hline HGD & $\begin{array}{l}\text { Percentage of soils in hydrologic group D. Hydrologic group D soils have very slow } \\
\text { infiltration rates. Soils are clayey, have a high water table, or have a shallow impervious } \\
\text { layer. }\end{array}$ \\
\hline AWCAVE & $\begin{array}{l}\text { Average value for the range of available water capacity for the soil layer or horizon (inches of } \\
\text { water per inches of soil depth) }\end{array}$ \\
\hline PERMAVE & Average permeability (inches/hour) \\
\hline
\end{tabular}




\begin{tabular}{|c|c|}
\hline Variable Name & Description \\
\hline BDAVE & Average value of bulk density (grams per cubic centimeter) \\
\hline OMAVE & Average value of organic matter content (percent by weight) \\
\hline WTDEPAVE & Average value of depth to seasonally high water table (feet) \\
\hline ROCKDEPAVE & Average value of total soil thickness examined (inches) \\
\hline NO4AVE & $\begin{array}{l}\text { Average value of percent by weight of soil material less than } 3 \text { inches in size and passing a } \\
\text { No. } 4 \text { sieve }(5 \mathrm{~mm})\end{array}$ \\
\hline NO200AVE & $\begin{array}{l}\text { Average value of percent by weight of soil material less than } 3 \text { inches in size and passing a } \\
\text { No. } 200 \text { sieve }(.074 \mathrm{~mm})\end{array}$ \\
\hline NO10AVE & $\begin{array}{l}\text { Average value of percent by weight of soil material less than } 3 \text { inches in size and passing a } \\
\text { No. } 10 \text { sieve }(2 \mathrm{~mm})\end{array}$ \\
\hline CLAYAVE & Average value of clay content (percentage) \\
\hline SILTAVE & Average value of silt content (percentage) \\
\hline SANDAVE & Average value of sand content (percentage) \\
\hline KFACT_UP & $\begin{array}{l}\text { Average K-factor value for the uppermost soil horizon in each soil component. K-factor is an } \\
\text { erodibility factor which quantifies the susceptibility of soil particles to detachment and } \\
\text { movement by water. The K-factor is used in the Universal Soil Loss Equation (USLE) to } \\
\text { estimate soil loss by water. Higher values of K-factor indicate greater potential for erosion }\end{array}$ \\
\hline RFACT & $\begin{array}{l}\text { Rainfall and Runoff factor ("R factor" of Universal Soil Loss Equation); average annual value } \\
\text { for period } 1971-2000\end{array}$ \\
\hline $\begin{array}{l}\text { ELEV_MEAN_M_BASI } \\
\mathrm{N}\end{array}$ & Mean watershed elevation (meters) from $100 \mathrm{~m}$ National Elevation Dataset \\
\hline ELEV_MAX_M_BASIN & Maximum watershed elevation (meters) from 100m National Elevation Dataset \\
\hline ELEV MIN M BASIN & $\begin{array}{l}\text { Minimum watershed elevation (meters) from 100m National Elevation Dataset (may include } \\
\text { sinks) }\end{array}$ \\
\hline $\begin{array}{l}\text { ELEV_MEDIAN_M_BA } \\
\text { SIN }\end{array}$ & Median watershed elevation (meters) from 100m National Elevation Dataset \\
\hline ELEV_STD_M_BASIN & $\begin{array}{l}\text { Standard deviation of elevation (meters) across the watershed from } 100 \mathrm{~m} \text { National Elevation } \\
\text { Dataset }\end{array}$ \\
\hline RRMEAN & $\begin{array}{l}\text { Dimensionless elevation - relief ratio, calculated as (ELEV_MEAN - } \\
\text { ELEV_MIN)/(ELEV_MAX - ELEV_MIN). }\end{array}$ \\
\hline RRMEDIAN & $\begin{array}{l}\text { Dimensionless elevation - relief ratio, calculated as (ELEV_MEDIAN - } \\
\text { ELEV_MIN)/(ELEV_MAX - ELEV_MIN). }\end{array}$ \\
\hline SLOPE PCT & $\begin{array}{l}\text { Mean watershed slope, percent. Derived from } 100 \mathrm{~m} \text { resolution National Elevation Dataset, } \\
\text { so slope values may differ from those calculated from data of other resolutions. }\end{array}$ \\
\hline ASPECT_DEGREES & $\begin{array}{l}\text { Mean watershed aspect, degrees (degrees of the compass, } 0-360 \text { ). Derived from } 100 \mathrm{~m} \\
\text { resolution National Elevation Data. } 0 \text { and } 360 \text { point to north. Because of the national Albers } \\
\text { projection actual aspect may vary. }\end{array}$ \\
\hline $\begin{array}{l}\text { ASPECT_NORTHNES } \\
\text { S }\end{array}$ & $\begin{array}{l}\text { Aspect "northness". Ranges from }-1 \text { to } 1 \text {. Value of } 1 \text { means watershed is facing/draining } \\
\text { due north, value of }-1 \text { means watershed is facing/draining due south. }\end{array}$ \\
\hline ASPECT_EASTNESS & $\begin{array}{l}\text { Aspect "eastness". Ranges from }-1 \text { to } 1 \text {. Value of } 1 \text { means watershed is facing/draining due } \\
\text { east, value of }-1 \text { means watershed is facing/draining due west. }\end{array}$ \\
\hline
\end{tabular}

\section{Appendix B}

Goodness-of-fit scores for all models. The period used for scoring was 10/1/1987 to 9/30/2010. 10/1/1985 to 9/30/1987 was discarded as a warm-up period. 


\begin{tabular}{|c|c|c|c|c|c|}
\hline USGS Gage ID & HRU size class & $r$ & NSE & IOA & PB \\
\hline 06043500 & 1 & 0.7202 & -11.61 & 0.47 & $171.47 \%$ \\
\hline 06043500 & 2 & 0.7307 & -11.41 & 0.48 & $171.87 \%$ \\
\hline 06043500 & 3 & 0.732 & -11.39 & 0.48 & $172.03 \%$ \\
\hline 06043500 & 4 & 0.7391 & -11.24 & 0.49 & $172.27 \%$ \\
\hline 06043500 & 5 & 0.7514 & -11.01 & 0.49 & $172.46 \%$ \\
\hline 06043500 & 6 & 0.7534 & -10.98 & 0.49 & $172.64 \%$ \\
\hline 06280300 & 1 & 0.721 & -0.21 & 0.79 & $23.23 \%$ \\
\hline 06280300 & 2 & 0.7373 & -0.11 & 0.8 & $23.94 \%$ \\
\hline 06280300 & 3 & 0.7397 & -0.11 & 0.81 & $24.21 \%$ \\
\hline 06280300 & 4 & 0.7406 & -0.1 & 0.81 & $24.54 \%$ \\
\hline 06280300 & 5 & 0.7492 & -0.06 & 0.81 & $24.94 \%$ \\
\hline 06280300 & 6 & 0.7504 & -0.05 & 0.81 & $24.95 \%$ \\
\hline 08324000 & 1 & 0.1682 & -0.36 & 0.39 & $-78.53 \%$ \\
\hline 08324000 & 2 & 0.1691 & -0.35 & 0.39 & $-79.30 \%$ \\
\hline 08324000 & 3 & 0.1695 & -0.34 & 0.39 & $-79.27 \%$ \\
\hline 08324000 & 4 & 0.1722 & -0.34 & 0.39 & $-78.22 \%$ \\
\hline 08324000 & 5 & 0.1739 & -0.33 & 0.39 & $-77.19 \%$ \\
\hline 08324000 & 6 & 0.1744 & -0.33 & 0.39 & $-76.62 \%$ \\
\hline 09447800 & 1 & 0.4062 & -0.17 & 0.57 & $217.30 \%$ \\
\hline 09447800 & 2 & 0.4038 & -0.18 & 0.57 & $228.55 \%$ \\
\hline 09447800 & 3 & 0.4038 & -0.18 & 0.57 & $228.55 \%$ \\
\hline 09447800 & 4 & 0.4099 & -0.15 & 0.58 & $223.29 \%$ \\
\hline 09447800 & 5 & 0.4068 & -0.18 & 0.57 & $235.12 \%$ \\
\hline 09447800 & 6 & 0.4068 & -0.18 & 0.57 & $237.43 \%$ \\
\hline 09494000 & 1 & 0.5598 & -6.72 & 0.48 & $204.25 \%$ \\
\hline 09494000 & 2 & 0.574 & -5.98 & 0.5 & $200.75 \%$ \\
\hline 09494000 & 3 & 0.5742 & -5.98 & 0.5 & $200.17 \%$ \\
\hline 09494000 & 4 & 0.5747 & -5.9 & 0.5 & $200.53 \%$ \\
\hline 09494000 & 5 & 0.5731 & -5.89 & 0.5 & $201.24 \%$ \\
\hline 09494000 & 6 & 0.5735 & -5.89 & 0.5 & $201.22 \%$ \\
\hline 09497800 & 1 & 0.4481 & -0.79 & 0.59 & $98.10 \%$ \\
\hline 09497800 & 2 & 0.4548 & -0.72 & 0.6 & $99.30 \%$ \\
\hline 09497800 & 3 & 0.457 & -0.71 & 0.6 & $99.49 \%$ \\
\hline 09497800 & 4 & 0.4624 & -0.7 & 0.6 & $99.04 \%$ \\
\hline 09497800 & 5 & 0.4639 & -0.69 & 0.61 & $100.96 \%$ \\
\hline 09497800 & 6 & 0.4641 & -0.69 & 0.61 & $101.00 \%$ \\
\hline 10308200 & 1 & 0.3154 & -3.98 & 0.41 & $84.53 \%$ \\
\hline 10308200 & 2 & 0.3142 & -3.84 & 0.42 & $85.02 \%$ \\
\hline 10308200 & 3 & 0.3142 & -3.84 & 0.42 & $85.13 \%$ \\
\hline 10308200 & 4 & 0.3183 & -3.7 & 0.42 & $85.37 \%$ \\
\hline
\end{tabular}




\begin{tabular}{|c|c|c|c|c|c|}
\hline USGS Gage ID & HRU size class & $r$ & NSE & IoA & PB \\
\hline 10308200 & 5 & 0.3179 & -3.68 & 0.42 & $85.49 \%$ \\
\hline 10308200 & 6 & 0.3175 & -3.64 & 0.42 & $85.65 \%$ \\
\hline 11266500 & 1 & 0.683 & -0.04 & 0.78 & $39.69 \%$ \\
\hline 11266500 & 2 & 0.7105 & 0.06 & 0.8 & $40.03 \%$ \\
\hline 11266500 & 3 & 0.7172 & 0.07 & 0.81 & $41.94 \%$ \\
\hline 11266500 & 4 & 0.7291 & 0.12 & 0.82 & $41.46 \%$ \\
\hline 11266500 & 5 & 0.7344 & 0.13 & 0.82 & $41.93 \%$ \\
\hline 11266500 & 6 & 0.7344 & 0.13 & 0.82 & $41.95 \%$ \\
\hline 11473900 & 1 & 0.4863 & 0.15 & 0.64 & $29.62 \%$ \\
\hline 11473900 & 2 & 0.5164 & 0.2 & 0.66 & $29.84 \%$ \\
\hline 11473900 & 3 & 0.5205 & 0.2 & 0.67 & $29.90 \%$ \\
\hline 11473900 & 4 & 0.5172 & 0.2 & 0.66 & $30.24 \%$ \\
\hline 11473900 & 5 & 0.5207 & 0.2 & 0.67 & $30.50 \%$ \\
\hline 11473900 & 6 & 0.5219 & 0.2 & 0.67 & $30.59 \%$ \\
\hline 11482500 & 1 & 0.1629 & -0.9 & 0.37 & $87.17 \%$ \\
\hline 11482500 & 2 & 0.1642 & -0.89 & 0.37 & $87.19 \%$ \\
\hline 11482500 & 3 & 0.1642 & -0.89 & 0.37 & $87.19 \%$ \\
\hline 11482500 & 4 & 0.1674 & -0.87 & 0.37 & $87.19 \%$ \\
\hline 11482500 & 5 & 0.167 & -0.86 & 0.37 & $87.64 \%$ \\
\hline 11482500 & 6 & 0.167 & -0.86 & 0.37 & $87.72 \%$ \\
\hline 11522500 & 1 & 0.0062 & -3.2 & 0.2 & $70.89 \%$ \\
\hline 11522500 & 2 & 0.008 & -3.09 & 0.21 & $71.04 \%$ \\
\hline 11522500 & 3 & 0.0082 & -3.08 & 0.21 & $71.02 \%$ \\
\hline 11522500 & 4 & 0.0119 & -3.08 & 0.21 & $71.20 \%$ \\
\hline 11522500 & 5 & 0.012 & -3.06 & 0.21 & $71.33 \%$ \\
\hline 11522500 & 6 & 0.012 & -3.06 & 0.21 & $71.44 \%$ \\
\hline 11528700 & 1 & 0.1471 & -2.24 & 0.29 & $153.43 \%$ \\
\hline 11528700 & 2 & 0.1513 & -2.16 & 0.3 & $153.94 \%$ \\
\hline 11528700 & 3 & 0.1526 & -2.14 & 0.3 & $154.11 \%$ \\
\hline 11528700 & 4 & 0.1556 & -2.12 & 0.3 & $154.36 \%$ \\
\hline 11528700 & 5 & 0.1599 & -2.11 & 0.31 & $154.75 \%$ \\
\hline 11528700 & 6 & 0.1628 & -2.1 & 0.31 & $154.91 \%$ \\
\hline 11532500 & 1 & 0.035 & -0.49 & 0.27 & $36.53 \%$ \\
\hline 11532500 & 2 & 0.0451 & -0.47 & 0.28 & $36.70 \%$ \\
\hline 11532500 & 3 & 0.0452 & -0.46 & 0.28 & $36.71 \%$ \\
\hline 11532500 & 4 & 0.0436 & -0.46 & 0.28 & $36.91 \%$ \\
\hline 11532500 & 5 & 0.0425 & -0.46 & 0.28 & $36.78 \%$ \\
\hline 11532500 & 6 & 0.0443 & -0.46 & 0.28 & $36.86 \%$ \\
\hline 12035000 & 1 & 0.4936 & 0.21 & 0.56 & $-26.09 \%$ \\
\hline 12035000 & 2 & 0.4954 & 0.21 & 0.56 & $-26.14 \%$ \\
\hline
\end{tabular}




\begin{tabular}{|c|c|c|c|c|c|}
\hline USGS Gage ID & HRU size class & $r$ & NSE & IoA & PB \\
\hline 12035000 & 3 & 0.4962 & 0.21 & 0.56 & $-26.15 \%$ \\
\hline 12035000 & 4 & 0.4962 & 0.21 & 0.56 & $-26.15 \%$ \\
\hline 12035000 & 5 & 0.4972 & 0.21 & 0.56 & $-26.14 \%$ \\
\hline 12035000 & 6 & 0.4973 & 0.21 & 0.56 & $-26.14 \%$ \\
\hline 12040500 & 1 & -0.3675 & -0.6 & 0.08 & $-2.09 \%$ \\
\hline 12040500 & 2 & -0.3679 & -0.6 & 0.08 & $-2.00 \%$ \\
\hline 12040500 & 3 & -0.368 & -0.6 & 0.08 & $-2.01 \%$ \\
\hline 12040500 & 4 & -0.368 & -0.6 & 0.08 & $-1.99 \%$ \\
\hline 12040500 & 5 & -0.3682 & -0.61 & 0.08 & $-1.15 \%$ \\
\hline 12040500 & 6 & -0.3682 & -0.61 & 0.08 & $-1.15 \%$ \\
\hline 12189500 & 1 & -0.1413 & -0.56 & 0.23 & $-38.61 \%$ \\
\hline 12189500 & 2 & -0.1419 & -0.56 & 0.23 & $-38.64 \%$ \\
\hline 12189500 & 3 & -0.1421 & -0.56 & 0.23 & $-38.62 \%$ \\
\hline 12189500 & 4 & -0.1424 & -0.56 & 0.23 & $-38.46 \%$ \\
\hline 12189500 & 5 & -0.1424 & -0.56 & 0.23 & $-38.39 \%$ \\
\hline 12189500 & 6 & -0.1418 & -0.55 & 0.23 & $-38.31 \%$ \\
\hline 12358500 & 1 & 0.6832 & 0.15 & 0.8 & $0.35 \%$ \\
\hline 12358500 & 2 & 0.6885 & 0.17 & 0.81 & $0.34 \%$ \\
\hline 12358500 & 3 & 0.6897 & 0.17 & 0.81 & $0.33 \%$ \\
\hline 12358500 & 4 & 0.6938 & 0.19 & 0.81 & $0.37 \%$ \\
\hline 12358500 & 5 & 0.6969 & 0.2 & 0.82 & $0.54 \%$ \\
\hline 12358500 & 6 & 0.6985 & 0.2 & 0.82 & $0.65 \%$ \\
\hline 12411000 & 1 & 0.6467 & 0.36 & 0.79 & $-5.53 \%$ \\
\hline 12411000 & 2 & 0.647 & 0.37 & 0.79 & $-5.43 \%$ \\
\hline 12411000 & 3 & 0.6471 & 0.37 & 0.79 & $-5.44 \%$ \\
\hline 12411000 & 4 & 0.6474 & 0.37 & 0.79 & $-5.33 \%$ \\
\hline 12411000 & 5 & 0.6484 & 0.37 & 0.79 & $-5.12 \%$ \\
\hline 12411000 & 6 & 0.6486 & 0.37 & 0.79 & $-5.07 \%$ \\
\hline 12413000 & 1 & 0.3357 & -1.3 & 0.51 & $35.30 \%$ \\
\hline 12413000 & 2 & 0.336 & -1.29 & 0.51 & $35.35 \%$ \\
\hline 12413000 & 3 & 0.3361 & -1.29 & 0.51 & $35.37 \%$ \\
\hline 12413000 & 4 & 0.3362 & -1.29 & 0.51 & $35.45 \%$ \\
\hline 12413000 & 5 & 0.3363 & -1.29 & 0.51 & $35.58 \%$ \\
\hline 12413000 & 6 & 0.3361 & -1.29 & 0.51 & $35.68 \%$ \\
\hline 12414500 & 1 & 0.2261 & -4.21 & 0.37 & $87.80 \%$ \\
\hline 12414500 & 2 & 0.2293 & -4.17 & 0.37 & $87.89 \%$ \\
\hline 12414500 & 3 & 0.2297 & -4.16 & 0.37 & $87.92 \%$ \\
\hline 12414500 & 4 & 0.2309 & -4.23 & 0.37 & $89.52 \%$ \\
\hline 12414500 & 5 & 0.235 & -4.21 & 0.37 & $89.64 \%$ \\
\hline 12414500 & 6 & 0.2356 & -4.2 & 0.37 & $89.70 \%$ \\
\hline
\end{tabular}




\begin{tabular}{|c|c|c|c|c|c|}
\hline USGS Gage ID & HRU size class & $r$ & NSE & IoA & PB \\
\hline 12451000 & 1 & 0.2108 & -0.4 & 0.49 & $-56.12 \%$ \\
\hline 12451000 & 2 & 0.2074 & -0.4 & 0.49 & $-56.06 \%$ \\
\hline 12451000 & 3 & 0.2025 & -0.4 & 0.49 & $-55.92 \%$ \\
\hline 12451000 & 4 & 0.2026 & -0.4 & 0.49 & $-55.69 \%$ \\
\hline 12451000 & 5 & 0.2018 & -0.4 & 0.49 & $-55.56 \%$ \\
\hline 12451000 & 6 & 0.2341 & -0.49 & 0.49 & $-76.17 \%$ \\
\hline 13010065 & 1 & 0.6469 & -0.63 & 0.73 & $30.12 \%$ \\
\hline 13010065 & 2 & 0.645 & -0.4 & 0.74 & $29.52 \%$ \\
\hline 13010065 & 3 & 0.6672 & -0.35 & 0.76 & $29.74 \%$ \\
\hline 13010065 & 4 & 0.6763 & -0.32 & 0.76 & $29.96 \%$ \\
\hline 13010065 & 5 & 0.6825 & -0.29 & 0.77 & $30.22 \%$ \\
\hline 13010065 & 6 & 0.6841 & -0.29 & 0.77 & $30.29 \%$ \\
\hline 13011900 & 1 & 0.3889 & -0.14 & 0.58 & $-42.53 \%$ \\
\hline 13011900 & 2 & 0.3805 & -0.12 & 0.57 & $-41.94 \%$ \\
\hline 13011900 & 3 & 0.3805 & -0.12 & 0.57 & $-41.94 \%$ \\
\hline 13011900 & 4 & 0.3778 & -0.12 & 0.57 & $-41.85 \%$ \\
\hline 13011900 & 5 & 0.3799 & -0.11 & 0.57 & $-41.75 \%$ \\
\hline 13011900 & 6 & 0.3792 & -0.11 & 0.57 & $-41.71 \%$ \\
\hline 13023000 & 1 & 0.7297 & -3.88 & 0.63 & $57.32 \%$ \\
\hline 13023000 & 2 & 0.731 & -3.87 & 0.63 & $57.48 \%$ \\
\hline 13023000 & 3 & 0.7323 & -3.86 & 0.63 & $57.57 \%$ \\
\hline 13023000 & 4 & 0.748 & -3.69 & 0.64 & $57.91 \%$ \\
\hline 13023000 & 5 & 0.7535 & -3.63 & 0.64 & $58.13 \%$ \\
\hline 13023000 & 6 & 0.7568 & -3.6 & 0.64 & $58.34 \%$ \\
\hline 13161500 & 1 & 0.3811 & -0.2 & 0.56 & $-47.39 \%$ \\
\hline 13161500 & 2 & 0.3815 & -0.2 & 0.56 & $-47.18 \%$ \\
\hline 13161500 & 3 & 0.3929 & -0.17 & 0.57 & $-45.16 \%$ \\
\hline 13161500 & 4 & 0.3939 & -0.17 & 0.58 & $-44.62 \%$ \\
\hline 13161500 & 5 & 0.3973 & -0.17 & 0.58 & $-43.88 \%$ \\
\hline 13161500 & 6 & 0.4001 & -0.17 & 0.58 & $-43.15 \%$ \\
\hline 13185000 & 1 & 0.7508 & -0.81 & 0.76 & $23.46 \%$ \\
\hline 13185000 & 2 & 0.7593 & -0.64 & 0.77 & $31.42 \%$ \\
\hline 13185000 & 3 & 0.7596 & -0.65 & 0.77 & $32.20 \%$ \\
\hline 13185000 & 4 & 0.7607 & -0.64 & 0.77 & $33.74 \%$ \\
\hline 13185000 & 5 & 0.759 & -0.64 & 0.77 & $34.65 \%$ \\
\hline 13185000 & 6 & 0.7596 & -0.65 & 0.77 & $35.15 \%$ \\
\hline 13235000 & 1 & 0.6208 & -2.76 & 0.61 & $47.99 \%$ \\
\hline 13235000 & 2 & 0.6511 & -2.54 & 0.64 & $48.30 \%$ \\
\hline 13235000 & 3 & 0.6614 & -2.47 & 0.64 & $48.39 \%$ \\
\hline 13235000 & 4 & 0.6639 & -2.45 & 0.64 & $48.59 \%$ \\
\hline
\end{tabular}




\begin{tabular}{|c|c|c|c|c|c|}
\hline \hline USGS Gage ID & HRU size class & $\boldsymbol{r}$ & NSE & IOA & PB \\
\hline \hline 13235000 & 5 & 0.6724 & -2.38 & 0.65 & $49.06 \%$ \\
\hline 13235000 & 6 & 0.6738 & -2.37 & 0.65 & $49.18 \%$ \\
\hline 14301000 & 1 & 0.6166 & 0.36 & 0.7 & $-18.87 \%$ \\
\hline 14301000 & 2 & 0.6182 & 0.37 & 0.7 & $-18.85 \%$ \\
\hline 14301000 & 3 & 0.6184 & 0.37 & 0.7 & $-18.83 \%$ \\
\hline 14301000 & 4 & 0.6199 & 0.37 & 0.71 & $-18.76 \%$ \\
\hline 14301000 & 5 & 0.6203 & 0.37 & 0.71 & $-18.71 \%$ \\
\hline 14301000 & 6 & 0.6203 & 0.37 & 0.71 & $-18.68 \%$ \\
\hline 14306500 & 1 & 0.6327 & 0.39 & 0.73 & $-15.99 \%$ \\
\hline 14306500 & 2 & 0.6332 & 0.39 & 0.73 & $-15.76 \%$ \\
\hline 14306500 & 3 & 0.6332 & 0.39 & 0.73 & $-15.76 \%$ \\
\hline 14306500 & 4 & 0.6333 & 0.39 & 0.73 & $-15.72 \%$ \\
\hline 14306500 & 5 & 0.6337 & 0.39 & 0.73 & $-15.58 \%$ \\
\hline 14306500 & 6 & 0.6337 & 0.39 & 0.73 & $-15.53 \%$ \\
\hline 14400000 & 1 & -0.0146 & -0.26 & 0.25 & $2.89 \%$ \\
\hline 14400000 & 2 & -0.0129 & -0.25 & 0.25 & $2.86 \%$ \\
\hline 14400000 & 3 & -0.013 & -0.25 & 0.25 & $2.87 \%$ \\
\hline 14400000 & 4 & -0.0025 & -0.24 & 0.25 & $3.10 \%$ \\
\hline 14400000 & 5 & -0.0039 & -0.24 & 0.25 & $3.09 \%$ \\
\hline 14400000 & 6 & -0.004 & -0.24 & 0.25 & $3.11 \%$ \\
\hline
\end{tabular}

